Florida International University FIU Digital Commons

11-15-2005

\title{
Politics and prayer in West Perrine, Florida : civic social capital and the black church
}

Susan Oltman Fink

Florida International University

DOI: $10.25148 /$ etd.FI15101400

Follow this and additional works at: https://digitalcommons.fiu.edu/etd

Part of the African American Studies Commons, Civic and Community Engagement Commons, and the Religion Commons

\section{Recommended Citation}

Fink, Susan Oltman, "Politics and prayer in West Perrine, Florida : civic social capital and the black church" (2005). FIU Electronic Theses and Dissertations. 3324.

https://digitalcommons.fiu.edu/etd/3324

This work is brought to you for free and open access by the University Graduate School at FIU Digital Commons. It has been accepted for inclusion in FIU Electronic Theses and Dissertations by an authorized administrator of FIU Digital Commons. For more information, please contact dcc@fiu.edu. 


\section{FLORIDA INTERNATIONAL UNIVERSITY}

Miami, Florida

POLITICS AND PRAYER IN WEST PERRINE, FLORIDA:

CIVIC SOCIAL CAPITAL AND THE BLACK CHURCH

A thesis submitted in partial fulfillment of the

requirements for the degree of

MASTER OF ARTS

in

RELIGIOUS STUDIES

by

Susan Oltman Fink 
To: Interim Dean Mark Szuchman

College of Arts and Sciences

This thesis, written by Susan Oltman Fink, and entitled Politics and Prayer in West Perrine, Florida: Civic Social Capital and the Black Church, having been approved in respect to style and intellectual content, is referred to you for judgment.

We have read this thesis and recommend that it be approved.

Alex Stepick

Deborah Dash Moore

Steven Heine

Lesley Northup

Date of Defense: November 15, 2005

The thesis of Susan Oltman Fink is approved.

Christine Gudorf, Major Professor

Interim Dean Mark Szuchman College of Arts and Sciences

Dean Douglas Wartzok

University Graduate School 
(C) Copyright 2005 by Susan Oltman Fink

All rights reserved. 


\section{DEDICATION}

I dedicate this thesis to my husband, Jeffrey, who provided me with much excellent advice and help in the early phase of this project, and whose patience, understanding and love throughout its long duration was indispensable to the completion of this work. 


\section{ACKNOWLEDGMENTS}

I had been a part-time graduate student in FIU's Religious Studies Department for about three years, experiencing the diversity of religious expression by sampling religions of India (with Nathan Katz), Buddhism as it made its way across China and into Korea and Japan (with Steve Heine), Temple Era Judaism and Christianity (with Eric Larson), and Jewish mysticism (with Oren Steir), when I took a course called the Jewish Political Tradition with visiting Davidson scholar, the late Daniel Elazar. My work with Dr. Elazar inspired this thesis. He taught me his unique sociological approach and introduced me to field research, which led to my desire to study religion anthropologically,

I therefore jumped at the opportunity to join a PEW funded FIU research project to study religion, immigration, and civic life in Miami. I want to thank my entire team, including principles Alex Stepick, Terry Rey, and Sarah Mahler, and also Carol Stepick. I developed the art of field research under Alex's guidance, discussing every interview and participant observation with him and how it related to the design of the project.

I want to thank my committee: to Chris Gudorf, who constantly challenged me to further my analysis, to Deborah Dash Moore, who met with me weekly while at FIU as a visiting Davidson scholar and helped me begin to work out the theoretical framework of my thesis, to Leslie Northup for her expertise in the area of American Protestant religions, and to Steve Heine, with whom I worked previously, and who graciously agreed to replace Terry Rey, who left FIU a few months before my defense. I also want to thank Terry for his many suggestions, enthusiasm for my thesis, and support.

Finally, I am indebted to the people of Perrine who opened up their hearts to me in the hopes that their story be told. I hope I have not disappointed them. 


\section{ABSTRACT OF THE THESIS \\ POLITICS AND PRAYER IN WEST PERRINE, FLORIDA: \\ CIVIC SOCIAL CAPITAL AND THE BLACK CHURCH \\ by}

Susan Oltman Fink

Florida International University, 2005

Miami, Florida

Professor Christine Gudorf, Major Professor

This thesis traces the mechanisms and sources responsible for the generation of civic social capital (a set of shared norms and values that promote cooperation between groups, enabling them to participate in the political process) by black churches in West Perrine, Florida. Data for this thesis includes over fifty interviews and participant observations, archival records, newspaper articles, and scholarly journals.

Despite the institutional racism of the first half of the twentieth century, many blacks and whites in Perrine developed levels of trust significant enough to form an integrated local governing body, evidence of high levels of csc. At mid-century, when black and white interactions ceased, Perrine's csc decreased, leading to the deterioration of Perrine's social and physical conditions. Perrine's csc increased in the1980s by way of broad-based coalitions as Perrine's churches invested their csc in an effort to eradicate crime, clean up its neighborhood, and win back its youth. 


\section{TABLE OF CONTENTS}

CHAPTER

PAGE

PROLOGUE. .1

1. Mapping a Collective Political Understanding Through the Use of Cultural Imagery and Religious Ritual at a Public Site.

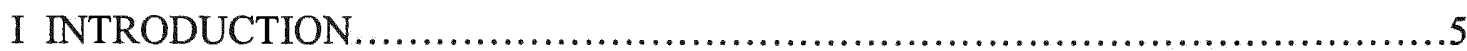

1. Theoretical Framework......................................................

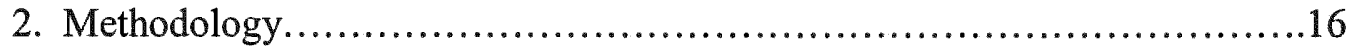

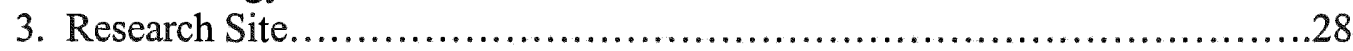

II. ACCUMULATION AND EXPENDITURE OF CIVIC SOCIAL CAPITAL IN THE BLACKCOMMUNITY...

1. Civic Social Capital Adheres in the Black Church.

2. Creating an African-American Identity Through The Use of American Cultural Images.

III. A HISTORY OF PERRINE PRIOR TO 1948: BUILDING CIVIC SOCIAL CAPITAL

1. Race Relations...........................................................44

2. Partial Residential Segregation........................................43

3. Bahamian and American Blacks, the Formation of their Churches, and their Contact with Whites........................................................45

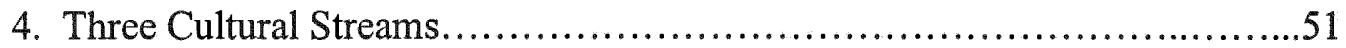

5. Generation of Trust and Reciprocity ....................................56

6. Generation of Civic Social Capital......................................60

7. Zones of Conflict: Generation of Civic Social Capital in the Black Church Through Conflict and Confrontation with the Dominant Society..............60

A. Education for Black Children....................................61

B. The Negro Council.............................................63

C. Black Freemasons as Police......................................65

D. Black Associational Ties.................................... . 72

E. Perrine Incorporates................................................

8. The "Incorporation Story" as an Instrument of Civic Social Capital Accumulation. 
1. Departure of the Agriculture Industry: Perrine's Bi-Racial Networks

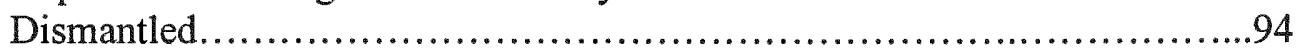

2. Residential Segregation in South Dade.....................................96

3. Richmond Heights: Seeds of Civic Social Capital Planted.....................99

4. Generational Rift Contributes to Increasing Isolation of Perrine..............106

5. Post WWII Race Relations...........................................108

6. Perrine's Participation in the National Civil Rights Movement...............111

7. Perrine's Churches Confront the Social and Economic Challenges of the Post War Era.......................................................... 115

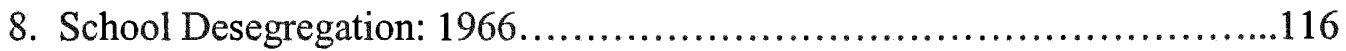

9. Churches are Unable to Help Young People Interpret White Culture..........118

10. Perrine's Growing Population Challenges its Cohesion......................121

11. Perrine is Ravaged by Urban Decay.....................................123

V. REACTIVATION OF PERRINE'S CIVIC SOCIAL CAPITAL: 1980-2002......131

1. Richmond Heights Comes to the Aid of Perrine.............................131

2. Rev. Walter Richardson as Spokesman for the Richmond Heights Group....133

3. Perrine's Fractured Community an Impediment to Civic Social Capital.......135

4. New Zone of Conflict is Identified: The Mustering of Civic Social Capital.

5. A Second Political Restructuring Enables the Creation of Additional Civic Social Capital

A. Neighborhood Resource Team (NRT)

B. Perrine's Political Power Base Expands in the Aftermath of Hurricane Andrew.

6. How Information Contributes to the Generation of Civic Social Capital......157

7. A "War of Religion".

8. Religious Institutional Responses to Social Problems

A. Churches Function as the Family................................173

B. Cultural Relevance.......................................175

C. Development of Civic Responsibility and Civic Skills in Youth......177

D. Strengthening Black Identity through Studying Black History.......180

9. The use of Religious Ritual to Generate Civic Social Capital by Mapping a Collective Political Understanding.

A. Prayer.

B. Preaching "The Word".

VI. New Rifts in the Community Lead to a Decline in Civic Social Capital..............208

VII. Perrine's Civic Social Capital Extends to National Policy......................222

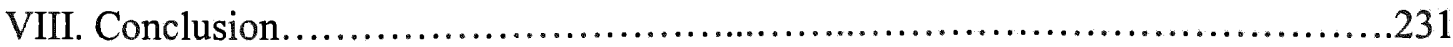


List of References. .

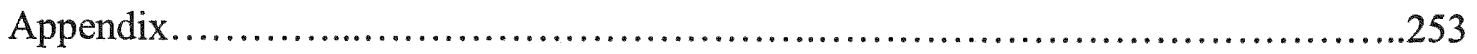




\section{Prologue}

A group of about sixty people packed the small satellite police station in the black neighborhood of Perrine, Florida, where a community meeting sponsored by the "Neighborhood Resource Team" was about to begin. Police officers, social workers, representatives from government agencies such as the Florida Department of Children and Families, pastors, businessmen, landlords of low income housing projects, and other citizens talked together in the meeting room and outside in the hallway. Suddenly Miami-Dade County Commissioner Dennis Moss arrived. The people in the hallway grew quiet and moved aside as the commissioner made his way through the crowd in the hallway and into the meeting room, shaking hands along his way and making his greetings. Everyone took their seats. At one side of a very large round table that occupied much of the room sat one contingent of the black leadership of West Perrine: Rev. Walter Richardson, pastor of the large Sweet Home Missionary Baptist Church of West Perrine; Commissioner Moss; Ed Hanna, developer and head of the Community Development Corporation (the "CDC"); and Officer Ron Tookes, the coordinator of the meeting and director of six Neighborhood Resource Teams ("NRTs") that operate in government and private housing projects in south Miami-Dade County. Sitting in two rows at the back of the room was the other contingent: the pastors and lay leadership that made up the West Perrine Christian Association, a group which Commissioner Moss affectionately referred as his "pastor leaders."1 Rev. Richardson began the meeting. 
Let us pray, letting God know how appreciative we are today for life. You have given us so much. Occasionally we are tempted to look at all that we don't have. We are tempted to complain about the status of our world. But in light of all that, we still are aware of the fact that you are in charge. This is your world. Thank you this morning for these concerned and caring citizens who have gathered, that we might lend our voice to your voice to make this community and others like this a place where justice prevails and peace resides. Help us to continue to have the courage of our convictions to face people insistent and people whose objects and objectives are to destroy what you have made. We come against anything that would seek to tear down your kingdom. And we pray for your presence. Thank you for our police department. Thank you for our commissioner, for those that give leadership. Thank you for men and women of God whose job it is to proclaim righteousness. We pray now, Lord, that all that we do as we work together will make this world and indeed this community a better place to live. Help us; we need your help. We pray for the thousands upon thousands of victims around this world who are suffering because of warfare, because of unjust systems, because of the threat of anthrax. We pray for the families, the victims, of the $9 / 11$ incident, to provide continual healing, even when we forget, because there is still more suffering. Bless us now. We'll be so careful to give you all the honor and all of the credit. And we ask of you, the most powerful name. Amen.,2

The group responded with a hearty "Amen." Many who had been calling out responses throughout Rev. Richardson's invocation now relaxed and began to joke with each other, having enjoyed what had just taken place. After a few minutes, when the banter began to die down, a series of "Amens" signaled that the next part of the meeting was about to commence.

Commissioner Moss then addressed the gathering, "Let me first of all say from the outset that it is always good to hear the Rev. Dr. Richardson pray." He then looked to the other end of the room to recognize the group he called the "pastor leaders" and praised their work in helping to improve the community. 
Next, Ed Hanna stepped up and someone quipped, affectionately, "Here's the Mayor of Perrine." The room exploded in laughter. This was unincorporated MiamiDade County so there was no mayor of Perrine itself, but if there were, it would undoubtably be Hanna, who through the CDC had implemented much of Perrine's redevelopment and clean-up effort. He reported on the housing improvements his group was working on, and said that the properties of two of the worst slum-lords in MiamiDade County, which were located in Perrine, had finally been demolished. He told the group that the county, in addition to the citizens of Perrine, also benefitted from such improvements in the quality of life in the neighborhood. He predicted that, when these properties were demolished and then redeveloped, twenty million dollars would come into the county. He thanked the police department for their help in recovering $\$ 30,000$ in stolen building materials. He also reported that the number of building code enforcement violations was decreasing, due to the joint efforts of the police department, the commissioner's office and community pressure.

Finally, Police Officer Ron Tookes introduced members of the NRTs and explained the work they were doing to improve housing, standards of living, and employment, and to eradicate crime. .

\section{Mapping a Collective Political Understanding Through the Use of Cultural Imagery and Religious Ritual at a Public Site}

In Perrine, civic social capital has been accumulated and deployed by individual churches and collectively through community-wide mechanisms, including coalitions 
between groups of church associations, businesses, government agencies, and politicians. Study of the Perrine church community is an excellent context for illustrating civic social capital because traditionally in the black community there has been no separation of the religious and the political, and because in the broader society, civic social capital can be accumulated in the religious sphere and spent in the political, and vice versa.

The NRT meeting described in the Prologue represents one moment in a long history of African-American ${ }^{3}$ confrontation, through its churches, with the dominant political system in America, which has sought to exclude blacks from the rights, privileges and opportunities extended to other groups in American society. It also illustrates the intersection of religion and politics in a broad-based coalition. The meeting opened, like other meetings involving the black church, by "having church," dramatizing how, in the African-American community, two domains, normally thought of as separate in the United States - that of the religious and that of the state - become integrated. Here was a public meeting, with a primary focus of community improvement, and it opened with the public worship of God, a religious ritual central to the African American religious experience. Such ritual affirms that, in the African American community, civic engagement is seen in a larger religious context, from which such civic engagement receives its form, its leadership, its meaning, its goals, and its optimism. The public ritual of prayer is a way for the community to empower and define itself, in particular because its purpose is to serve God. As God's partner, the community is given not only status in the local context, but in the global and sacred ones, too. The use of prayer in a government building by a prominent pastor, and with the sanction of government officials, legitimizes the message that this community wants to impart to the wider 
community, that God reigns supreme, that in God's Kingdom there is no separation between religion and the state, and that in the Kingdom this community is God's partner.

The prayer that Rev. Richardson delivered at the NRT meeting invokes central national cultural ideals of justice and peace, and links God's Kingdom of Heaven on Earth to America's government. At that meeting, Perrine's black community, negotiating their place in the wider community, acted in a police station, which has particular significance to this community because it is an office of the government at large but located within the geographical boundaries of its community. ${ }^{4}$ The police department is a particular government agency with which the community has had a long, mixed history. The drama that unfolded in the Prologue portrays, on the one hand, the black church in dynamic interaction with the State, arguing for the inclusion of the black community in a political system, which inclusion it has fought to secure for hundreds of years; and on the other hand, through Richardson's remarks, it places the black community as an equal player on the stage of the community at large. When Richardson asks the "concerned and caring citizens" at the meeting to "lend our voice to your voice," he links the goals to which African Americans aspire, "to make this community and others like this a place where justice prevails and peace resides" to those of America at large. Richardson is now a spokesman for a unified America when he articulates his vision of community, of the reign of God's Kingdom of Heaven on Earth over other systems of government, those "unjust systems" with "people insistent, and people whose objects and objectives are to destroy what you have made." 


\section{NOTES}

${ }^{1}$ Members of the West Perrine Christian Association in attendance included Bishop Simeon Watson, president of the Association and pastor of the Pentecostal Church of Our Lord and Savior Jesus Christ; Rev. Joe Sumpter, past president of the Association and pastor of St. Peter's Missionary Baptist Church; Bishop Ingraham of the Community Church of Christ Written in Heaven; Rev. Rosa McIntosh of the Church of God of Prophecy; Rev. Altheus Ferguson of the National Church of God. Neighborhood Resource Team Meeting, field notes by author, partial tape recording, Perrine, Fla., 28 Nov, 2001.

${ }^{2}$ Rev. Dr. Walter Richardson. Neighborhood Resource Team Meeting, field notes by author, partial tape recording, Perrine, Fla., 28 Nov. 2001.

${ }^{3}$ It will be necessary to the discussion in this thesis to distinguish between several different groups of people, who although of the same race, have characteristics, such as religion and place of origin, that differ from one another. I have sometimes found it difficult to find terms of reference that might be acceptable to all and have had to make do with inadequate terminology. I have tried to use terms these groups appear to use for themselves. White and black, of course, will be used to distinguish skin color, although as must be obvious, the line of demarcation here is often not clear. For the most part, I have divided groups of black people by their place of origin, such as "American" black and "Bahamian" black. I have used American black and African-American interchangeably as both usages are common forms.

${ }^{4}$ Thomas Tweed emphasizes the importance of social sites for amassing power: "Mapping a symbolic landscape and constructing a symbolic dwelling involve negotiations for meaning and power in natural environments and at social sites." (Thomas A. Tweed, ed., Retelling U.S. Religious History, [Berkeley: University of California Press, 1997], 12). 


\section{Introduction}

This thesis is about the accumulation and expenditure of civic social capital by black churches in West Perrine, Florida, a black enclave in south Miami-Dade County (formally called Dade County). ${ }^{1}$ It traces the mechanisms and sources responsible for the generation of this civic social capital from Perrine's early twentieth century beginnings as an agricultural village in the segregated South to the early twenty first century as it has emerged, impoverished and crime-ridden, as part of a sprawling metropolis. The thesis argues that churches in Perrine used religious resources to generate civic social capital, to activate stored civic social capital, to accumulate more of this capital, and to invest it in the community.

\section{Theoretical Framework}

The term "civic social capital" is a new term developed by Alex Stepick, Terry Rey and Sarah Mahler in their forthcoming book, Religion, Immigration and Civic Social Capital in Miami in an attempt to define and operationalize the term "social capital," a configuration of concepts that in its present incarnation began to take shape in the works of French sociologist Pierre Bourdieu and American sociologists James Coleman and Robert Putnam. Its current popularity stems from Putnam's 1993 seminal account of Italy's experiment in regional governance, in which he argued that levels of civic engagement were the most reliable predictors of how well the different regional governments were performing. ${ }^{2}$ The term social capital initially grew out of modern 
economists' notion of financial capital (tangible resources) and human capital (skills and education) and originally described the ability to secure resources for individual benefit. But in 1916, an insight by Lyda J. Hanifan, superintendent of schools in West Virginia, that the key to educational success lay in integrating the school's educational agenda and goals into the life of the local community, shifted the focus of social capital from the individual to collective life, focusing on the importance of networks and norms to facilitate collective action for mutual benefit. This notion was taken up by authors writing in the areas of urban renewal (in the 1950's and 1960's), racial segregation and poverty (in the 1970's), and education (in the 1980 's). ${ }^{3}$ Since then social capital has been cited in fields as diverse as social theory, economic development, family and youth behavioral problems, education, community life, democracy and governance, crime and violence, health, nutrition, urban development, and water management, ${ }^{4}$ leading Alejandro Portes to complain that the term has been "applied to so many events and in so many different contexts as to lose any distinct meaning.",5

These many applications of social capital have raised questions as to what exactly is social capital. Is social capital an attribute of individuals, as many economists maintain, or a feature of a whole society, as in their level of generalized trust, as some political scientists hold? Does social capital refer to the structures (networks and organizations) that make possible the transfer of ideas, information, and resources, or does it refer to the resources themselves? ${ }^{6}$ Or is social capital, as some social scientists suggest, coterminous with civil society itself? Woolcock has suggested that "there are different types, levels, or dimensions of social capital" ${ }^{17}$ and has called for more empirical research to further our understanding and conceptualization of social capital. At the same 
time he applauds Putnam's recent call for a more "lean and mean" definition of social capital, which he says has resulted in most of the leading writers in the field having adopted the more sociological definition centered primarily on networks and norms facilitating collective action. ${ }^{8}$

My research centers on the religious and political dimensions of social capital, the locus of which resides in the realm designated by some social scientists as "civil society." Civil society refers to the forms of communal and associational life (families, communities, churches, civic and cultural societies) located between the individual and the state that Alexis de Tocqueville noted and described in his analysis of American political life during the Jacksonian period. Tocqueville determined that these "voluntary associations" provide two functions necessary for the effective operation of a democracy, that of protecting individual liberty against the coercive powers of the state, and that of checking the dangers that rampant individualism posed to political life. Among the most important of these voluntary associations are America's churches, which, as Tocqueville noted, serve to maintain a sense of "public virtue" and thus mitigate the worst effects of democracy. ${ }^{9}$

As social scientist Francis Fukuyama has observed, Tocqueville might have been talking about social capital when he spoke about the public virtues religious institutions engender in the form of shared norms and values that promote cooperation. ${ }^{10}$ Indeed, America's Founding Fathers, irrespective of their own personal religious beliefs, understood that religion would play a central part in the new Republican political order, based on divided powers and self government. Religion encouraged the development of "republican virtues" (self-discipline, self-control, and self-reliance), without which the 
best political arrangements would fail. Religion also played a vital role in the cultivation of a moral order, essential to the new social order. In his farewell address, Washington warned his countrymen not to "indulge the supposition that morality can be maintained without religion," adding, "Whatever may be conceded to the influence of refined education on minds of peculiar structure, reason and experience both forbid us to expect that national morality can prevail in exclusion of religious principle."11

Tocqueville's observations about the relationship between American religious institutions and its form of democracy seem more in step with how many social scientists today view religion and politics (and ideal political forms) than to the way many prior theorists did. The question of how to view religion and politics, whether as strictly separate spheres or as having some level of interconnectedness, has been the subject of debates, discussions and theories among social scientists over the past five hundred years. The problematic relationship between religious and political power in the modern world was first addressed by the Protestant Reformation in Europe in the sixteenth century. This movement was accompanied and aided by the political theories of Locke and Montesquieu, who formulated a strict separation between religious and political power, with religion becoming a separate institution. These theories influenced the formation of modern political systems, and specifically the American democratic system. Many modern theorists, including Max Weber and Karl Marx, developed their frameworks positing a religious/secular dichotomy where the spheres of the political and economic are completely separated in the context of these debates. Marx in fact, maintained that mankind would eventually progress to the point where religion would be unnecessary. Other theorists, including Emile Durkheim, Clifford Geertz, David Chidester, and 
Thomas Tweed, have proposed the interrelatedness of religion and society. ${ }^{12}$ The theories of this second group of social scientists form the theoretical underpinnings for this thesis.

The assumptions on which this thesis rests are that both religion and politics are social networks, that they are both concerned with meaning and power, and that, as political scientist David Chidester maintains, they intersect "within the systematic distribution of power that constitutes any social network."13 As Geertz and Durkheim before him have pointed out, cultural systems produce collective symbols, myths and rituals that are used to mediate ultimate meaning and transcendent power. ${ }^{14}$ The intersection of the religious and political systems allow for a free-flow of these collective representations back and forth, from the religious sphere into the political and vice versa. ${ }^{15}$ These collective representations can then be used by groups as a type of currency that can be invested in the political system. This thesis will explore the use of such collective representations as they are used by Perrine's church community in the amassing and dispersion of civic social capital.

The creation of the term "civic social capital" is one attempt among many to give a more precise meaning to "social capital." The first intent is to shift the focus from social capital's emphasis on economic benefits to individuals to that of activities that benefit the collective. ${ }^{16}$ I adopt Putnam's "lean and mean" definition of social capital and define civic social capital as the information, trust, and norms of reciprocity inhering in one's social networks that facilitate collective civic action. Civic social capital is that aspect of social relationships responsible for shaping identities, values and aspirations that allow access to material as well as non-material resources. The second purpose for 
adopting the "civic" descriptor is to address the political aspect of collective activity. Social capital is more general in scope and describes man's social relationships. But "civic" social capital goes beyond the merely, social to describe a form of social capital that relates to participation in a polity. Civic social capital is generated by participation in the political process.

Along with problems of defining social capital, social scientists have struggled with the problem of how to measure it. Portes, Woolcock and Fukuyama, among others, have pointed out some of these difficulties. ${ }^{17}$ Physical and human capital can be used as input in economic models, but how does one quantify social capital? If social virtues such as honesty, reciprocity and dependability are cultivated, they can as easily be used for negative social goals as positive ones. For example these virtues may be directed only towards a small social group, enabling a clan or traditional tribe access to goods, but promoting hostility towards other groups and denying them access to the same goods. ${ }^{18}$ Therefore social networks by themselves are not a measure of social capital. Using trust as a standard of measurement also has its downside. For example small family businesses may exhibit high levels of trust within their micro-systems but equally high levels of distrust towards the State resulting in a two-tiered culture of honesty and loyalty towards family members but one of large scale corruption in the broader society. I have tried to resolve some of these problems by using Fukuyama's "positive radius of trust" standard as a way to indicate levels of civic social capital. Fukuyama suggests that increased social capital must include the extension of a "positive radius of trust" towards people who fall outside of one's social group, thus increasing the likelihood of a group participating more broadly in joint efforts. ${ }^{19}$ As will be shown in this case study, many of 
Perrine's religious groups, especially through their theologies of inclusiveness, have provided opportunities to cross social boundaries and bridge into the wider society while maintaining a distinctive African American identity.

Social capital's emphasis on trust, shared values and reciprocity speaks more about its collective aspect than it does about conflict and power. But understanding the part conflict plays may provide a clue to understanding how social capital is created. As Portes and Lindsay Paterson have suggested, it is during points of conflict that new networks are created, and these new relationships in turn forge new bonds of social capital: "If we ask, with Portes (1998) how and when social capital is created, perhaps the answer lies in moments of sharp social conflict, where power relations are shifting, and where the outcome is not determined in advance because there is a myriad of possible new networks to be formed. Each segment of civil society is forced to choose new allies. . . and thereby to create new bonds of social capital., ${ }^{20}$

David Chidester's definition of political power as "the network of power relationships in a society" offers an explanation of how political power (or civic social capital, as I am using the term) is distributed in society. ${ }^{21}$ In traditional political theory, power is thought of as the domination by one person or social unit over another. In Chidester's systems theory, power is not exerted in a one way direction. The 'powerful' are also "dominated by a network of power relations in order to keep the 'powerless' in their place." Political power, therefore, is concerned with more than just control. It is a system

or field of power relations which distributes power within a society. In this sense, power pervades social relations; it produces the very strategies through which individuals participate in society; and it generates powerful 
symbols, myths, and ideologies through which contending individuals and social groups are defined and define themselves. Power is the dynamic energy that infuses a social system.,"22

My own case study explores how civic social capital is generated in a particular community. It examines the mechanisms and sources that are responsible for its development, looking at the formation of networks, and how attitudes developed within these networks that both contributed to, and impeded, trust and norms of reciprocity. ${ }^{23}$ It views the generation of civic social capital within the context of the great cultural changes that occurred within American society during the course of the twentieth century. And it explores how Perrine's churches used cultural symbols as a means to preserve and to generate its civic social capital.

Drawing on Chidester's work, I propose that one of the ways civic social capital is generated is through zones of conflict. A zone of conflict is a situation of social tension between two or more power systems. ${ }^{24}$ This thesis examines two large zones of conflict in which Perrine's churches have engaged. The first conflict was set in the historical context of the American racist system of the first half of the twentieth century, one that denied blacks much, if any, participation in its political system, particularly in the South. On an institutional level, the zone of conflict occurred as black churches struggled with the dominant political system for services and opportunities denied them as members of a discriminated social group: in Perrine, churches struggled to obtain funding from Dade County's School Board for a colored public school, and they established an alternative police department because the county did not provide them with adequate protection against the Ku Klux Klan. The second zone of conflict occurred 
in the 1980 's as one faction in Perrine, as represented by its churches, waged a battle against a second faction, Perrine's drug dealers, and against the "secular influences" of a dominant society Perrine's fraternity of churches believed was all but destroying their community.

Two insights, those of "bridging interactions" and "weak ties," taken from social capital theory help demonstrate that civic social capital is increased when social groups create ties to other social groups beyond the confines of their intimate circle. Ties to outside groups allow for more effective information flows and increase the levels of trust between the disparate social groups that come together to work for a common cause. ${ }^{25}$

This case study will show that this indeed was true in Perrine. Despite the institutional racism of the first half of the twentieth century, there were substantial numbers of blacks and whites who, through positive contact with each other, developed enough trust to form an integrated local governing body. The coalition that they built is an example of high levels of civic social capital. Conversely, when the attempt at integration failed (due to outside forces - threats by the Ku Klux Klan among them), and whites moved out of Perrine, black and white interactions ceased. Living in a state of segregation, blacks in Perrine were then forced to form networks based on strong ties (ties between people of their own social group). Loss of contact with the outside world led to loss of information and to distrust of both whites and of other blacks in their community. The level of civic social capital decreased and social and physical conditions in Perrine deteriorated.

Only in the late 1980's did Perrine's civic social capital increase again, and this was by way of bridging interactions with blacks in a neighboring middle class 
neighborhood who had not been cut off from white society, as Perrine's blacks had, and later through broad-based coalitions involving government institutions, and white businesses and religious institutions. (The NRT meeting above is one example of this type of coalition as we will see below).

\section{Methodology}

The data for this thesis comes from multiple sources. The first is in the form of over fifty sets of field notes taken and interviews conducted by the author with individuals while I was working on a Florida International University research project on Religion, Immigration, and Civic Life in Miami from 2000-2003. This project was part of a five city research project funded by the PEW Charitable Trusts, Inc. Most of these interviews and field observations took place on site, in Perrine, Florida, but research was also conducted elsewhere in Miami Dade County for comparative purposes, specifically in a black Baptist church and religious school in Liberty City, in a black Baptist and Pentecostal mega-church in North Dade and in an ethnically mixed (comprised of Anglos and Mexican migrant workers) church in Homestead.

The second source is from archival records, including those kept by the Model Land Company, the company that Henry Flagler set up to oversee the management and sale of his land holdings (University of Miami Archives). These records show Flagler's extensive influence in the creation, continuation and maintenance of Perrine, including his part in helping to create black neighborhoods and churches to encourage black 
settlement. These records are invaluable to understanding black-white interactions in the early part of the twentieth century.

Other archival records consulted include histories and miscellaneous documents from the Historical Museum of Southern Florida, Miami, including the notes, documents, and tape recordings of interviews with early South Dade settlers that Miami historian Jean Taylor conducted and incorporated into her book, The Villages of South Dade.

The third source includes newspaper articles, including those from the Miami Herald, Miami News, Miami Metropolis, two journals that deal with Miami and South Florida (The Florida Historical Quarterly and Tequesta), unpublished documents (informal biographies given to me by participants and documents from government and non-government institutions), and census materials.

To understand Perrine's historical and social context I also conducted research on settlement patterns (of groups including Native Americans, escaped slaves, Europeans, and Bahamians) in early Florida history, especially in the Florida Keys and around Miami.

I also necessarily have researched the leading literature in black studies, a relatively young field (Wilmore, Cone, Raboteau, Marable, Paris, etc), histories of the black church in America (DuBois, Woodson, Frazier, Mays, Lincoln and Mamiya, Baer and Singer), Urban Studies (e.g. Drake and Cayton's landmark sociological study, Black Metropolis: A Study of Negro Life in a Northern City), and social theory and studies in American religion. 


\section{Research Site}

The following description of Perrine, taken from my field notes of October 10 , 2001 , is included to provide the reader with a flavor of the town that is the subject of this study. By many accounts, the following tour of Perrine presents a picture of a greatly improved Perrine, after considerable effort was expended by citizens and civic leaders in cleaning up Perrine. According to a number of residents, before Rev. Richardson began his clean up efforts in the mid 1980's, a drive through the streets of Perrine would risk endangering one's life. Some of the older residents have affectionately described an even earlier era of the Perrine they knew from their youth, when it was covered by farms. As one resident recounted, "If you stood at one end of Homestead Avenue, all you could see for miles was tomatoes, beans and potatoes." ${ }^{26}$ Mid twentieth-century Homestead Avenue itself was a thriving commercial and cultural center that attracted farmers from all over Southern Dade County to its many juke joints, theater, and stores. One resident showed me the wide easements on one of the streets behind his home from where the crop-dusting planes took off and also pointed out the site of an old Indian mound before it had been leveled for housing.

West Perrine is a sixteen square block area with about 9,000 residents, a black enclave, bordered by US $1,184^{\text {th }}$ Street, $107^{\text {th }}$ Avenue, and $169^{\text {th }}$ Street. All the religious institutions in West Perrine are Protestant (two are Jamaican, the rest are AfricanAmerican). There is also an Islamic mosque and a Hindu Temple. Just outside the enclave to the South, there are several Hispanic Pentecostal churches. Five blocks to the West (112 $2^{\text {th }}$ Avenue And $160^{\text {th }}$ Street) is a Catholic Church with a Saturday service in 
Spanish and Masses in English and Haitian Creole on Sunday. Across US 1, which itself is lined with luxury auto dealerships, is a middle-class white neighborhood with a large Baptist Church. Abutting Perrine to the north is Richmond Heights, the large-middle class black neighborhood often referred to in this study.

West Perrine is primarily residential, with a mix of single-family homes, public and private apartment complexes, and a few businesses located on Homestead Avenue and Lee Arthur Lawrence, Sr. Avenue including Jamaican restaurants, a convenience store, and a "night club." Also on Homestead Avenue are a CDC and several government buildings. There are two elementary schools and two parks. One of the parks is very small, with a memorial plaque honoring Ben Shavis, the president of Perrine's Negro Council who, in 1948, was in line to become Perrine's first black mayor. In one area several new homes are under construction. Except for a small cluster of duplexes most of West Perrine has single unit houses; most of them are small and on fairly large plots of land, relative to the surrounding neighborhoods. A few houses are very close together with small yards. The two-block area between $168^{\text {th }}$ Street and $170^{\text {th }}$ Street have newer houses, and there are five new duplexes being built there; but the rest of West Perrine is quite different from the areas outside of West Perrine itself, having many houses that are older and individually constructed compared to the newer more uniform houses elsewhere that are painted in earth-tones and are stylistically more modern, and because in West Perrine there are no sidewalks. There are also quite a few empty lots interspersed throughout, many of them with tall uncut grasses, some where crack houses had been torn down. There are abandoned automobiles in some of the lots, many with varying amounts of their insides removed. 
The colors of the houses vary widely. Many are the tropical greens, pinks and beiges popular during in an earlier era of South Florida's history. There are also quite a few homes painted in the distinctively Bahamian colors of fuschia, bright oranges, pinks, and royal blue.

The houses also vary in degree of upkeep. Some are meticulously maintained, but many are greatly in need of repainting and repair. Most have very little to no landscaping, yet a few are notable for yards that are highly decorated with landscaping and garden objects such as fountains and statues of animals. (I have been told that the houses with highly decorated yards indicate Bahamian residents). Other yards are cluttered, some having numerous cars parked in them, old tires, car parts, furniture, exercise equipment, etc.

Some of the houses in the community look as if they have not been touched since the devastating Hurricane Andrew hit South Florida in 1992. One such house, a wooden shack with its windows boarded up is on the corner of 182 Street and 102 Avenue. I since found out that this building is one of the quarters that housed tomato pickers during the first half of the twentieth century. A local historical preservation society plans to make this building an historical site.

It is obvious that many of the residents spend much of their time living outdoors, on their front lawns and porches. Many of the houses have plastic chairs outside their front doors. There are quite a few metal barrel barbeques in front yards and a number of yards with picnic tables that are covered by canopies supported by poles, next to barbeques. 
As I drive through the community, I am struck by the mode of transportation that is most commonly used: the bicycle. There is very little automobile traffic; most people who are out and about are either on foot or on a bicycle. During working hours, there are very few people on the streets. Between 3:30 and 4:00 groups of youth walk through the neighborhood, presumably returning home from school. By 5:00 there is a noticeable increase of people in the streets, walking and bicycling around and sitting in their yards. By 6:00 the streets and yards are full. There are many people on Lee Arthur Lawrence Ave. where there are package stores and other businesses.

The religious presence in West Perrine is readily apparent. It is remarkable that a one square mile area has twenty-three active churches, several that are not being used, and one that is under construction. Religious signs, many with quotes from the Bible dot the streets. There are signs that say: "Christ is Coming," "Pray," and "Mark: 1:15." (A translation of Mark 1:15 reads, "The time is fulfilled, and the kingdom of God has come near; repent, and believe in the good news"). Other signs read "Trust in Jesus," "Holy is the Lord," and "Joy in Jesus." The signs are printed on white or green rectangular streetsign boards and are posted on telephone poles on about $30 \%$ of the street corners.

As I pull up to the corner where the Church of the Kingdom of God is located, I see four men walking north on 102 Avenue. One man pushes a shopping cart filled with what looks like household articles. They look my way as I drive past them.

I pass a house with an American flag on a flag pole in its yard, and under a pair of shoes tied together on a telephone wire above the street. 
The House of God is beautifully cared for; much attention has been given to landscaping. There are Chinese fan palm trees planted around the entire perimeter of the building and parking lot. The parking lot is fenced in. The sign is large, and in the shape of a $\mathrm{V}$ which rises up in the middle. The message is written on both sides of the $\mathrm{V}$ so it may be viewed from whatever direction one approaches this church.

This church is located in the northwest quadrant of West Perrine, in the vicinity of the only new construction that appears to be taking place here except for a new Church that is under construction on $106^{\text {th }}$ Ave. and $173^{\text {rd }}$ St. [Rev. Alpheus Ferguson has been building this church for several years, ever since the County bought the property from under his former church, on Homestead Avenue] House of God is opposite an empty lot which has the cinder foundation of what looks to be a house. Also in that lot is a discarded red car with its innards torn out. The left side of the church faces the cinder block shells of five houses which appear to be under construction. They are two story constructions which are close together, in a style unlike other houses here.

There is a house with a police car in the driveway. I pass another small house which looks like it has been boarded up since the Hurricane; it has the house's address written on its walls, a customary practice to let insurance companies identify addresses when all other visible identification is lost. Many people sit outside their houses in plastic chairs, or they walk about. There is a house with a sign outside that says, "Keep off the Grass."

This one-room church at the corner of $183^{\text {rd }}$ Street and $107^{\text {th }}$ Avenue looks like it has been boarded up since the Hurricane. Although it doesn't look like it is in use, the lawn is freshly mown. I pass two abandoned cars with their innards stripped. One house 
that I pass has seven old cars out back and on the side. I pass another abandoned car with parts removed. I pass a house that has a rusted barbeque barrel and tables in the front. I pass a house with a satellite dish. There is a house on the corner of $178^{\text {th }}$ Street and $105^{\text {th }}$ Avenue which is well taken care of and which also has a satellite dish on its property. The yard is fenced in and has a display in the front garden. In the landscaped garden here is a stone replica of a deer, and a reindeer stands on either side of a statue of a black boy who is sitting. The van in the driveway says Mt. Sinai Missionary Baptist Church, Rev. Bell's church.

It is 5:30 and more and more people are out and about. I pass a house where people are barbequing in their front yard. There are four tables under an open tent and about 30 people are sitting around in the front yard, either at the tables or in chairs. There is a light drizzle.

At 6:00 PM, with people home from work. The streets are full. People are walking about and on bicycles or sitting out in front of their houses on porches or under canopies. Some were barbequing on their front lawns. It does not seem to matter that there is a slight drizzle.

I pull up to Mt. Calvary National Church of God in my Volvo station wagon and stop across the street, along side of a house where a man who looks to be in his sixties, wearing a soft cast on his arm, and a woman who might to be in her forties are sitting on the front porch. The woman is eating what appears to be her dinner. My windows are open and I write while looking at the Church across the street. I notice that the man is watching me and so I call out that I am a researcher, studying churches. He calls back saying that he hopes I will say something nice about the church I am writing about 
because it is his and it sure needs help. He added that I must be working pretty hard as he has been watching me drive by all afternoon.

We talk back and forth a bit, and the woman, who introduces herself as Brenda, takes her plate of food inside her house and then walks over to my car so we won't have to talk from a distance. I get out of the car and we stand and talk in the street for about twenty minutes. She seems friendly and interested in answering my questions, although she does not initiate conversation. In fact she does not express curiosity about the research I am doing, but she waits patiently until I finish asking my questions.

Early in our conversation, a thin woman, missing her front teeth and looking much older than she probably is, peddles towards us on her bicycle and chats with Brenda for a few minutes. She wears a long, rather striking Indian style skirt. Brenda talks with her in a compassionate manner which seemed to suggest that she is in a helping position with regard to her. [Later in the conversation, I learn that Brenda is very involved in her church's evangelistic activities.]

Brenda describes West Perrine as being where everyone comes for drugs. It is a place where anything goes, she says. In fact, her street is the worst in the neighborhood. People who live here are in a rut from which it is difficult to escape. I ask how parents from her church keep their children from the bad influences of the street. She answers that they take their children to every event they have at the Church, to all the Bible Study Classes, to the Youth Choir, and to the Prayer services. Anytime the parents are there, so are their children.

After leaving Mount Calvary, I drive west to Lee Arthur Lawrence $\left(105^{\text {th }}\right.$ Street) and make a right. I pass the "Paradise Jamaican Restaurant." There are many people on 
this street. Signs on this street include: "Get Right. Matt 24:44. Or get left." "Freedom in the Lord." (A translation of Matt 24:44 reads: "Therefore you also must be ready, for the Son of Man is coming at an unexpected hour.")

There is no sign outside of this wooden church I am passing. It is on a very large piece of land with no fence. I ask a postman if he knows the name of the church and he gets out of his truck and says he just delivered some mail to it. He approaches the church and shows me the letters and I read the name, "Triumph Church and Kingdom of God in Christ." He tells me to be careful.

Indeed, on the next block I meet five men who point at me as they walk down the street. They appear to be stopping cars. [I assume these men are drug dealers because at a later date I watched as a group behaving in a similar manner to this one transacted a drug deal a few yards from where I was interviewing a pastor on his front lawn in Perrine]. I pass by, turning back onto Homestead Avenue, past a housing project, and then past the Paradise Inn which advertises dancing and a disco.... 


\section{NOTES}

${ }^{1}$ Greater Miami, Metropolitian Miami, Miami-Dade County, and Dade County are used interchangeably, as distinguished by the City of Miami, which, in actuality, is a small geographic area. In 1999, the electorate of the county voted to change its name from Dade County to Miami-Dade County.

${ }^{2}$ Robert Putnam, Making Democracy Work: Civic Traditions in Modern Italy, (Princeton: Princeton University Press, 1993).

${ }^{3}$ Francis Fukuyama, The Great Disruption: Human Nature and the Reconstitution of Social Order, (New York: The Free Press, 1999), 19.

${ }^{4}$ Stephen Baron, John Field, and Tom Schuller, Social Capital: Critical Perspectives (New York: Oxford University Press, 2000), 25; Michael Woolcock, "Social Capital and Economic Development: Toward a Theoretical Synthesis and Policy Framework," Theory and Society 27/1 (1998): 193-196.

${ }^{5}$ Alejandro Portes, "Social Capital: Its Origins and Applications in Modern Sociology," Annual Review of Sociology 24 (1998):2; Stephen Baron, John Field, and Tom Schuller, Social Capital: Critical Perspectives (New York: Oxford University Press, 2000), 24.

${ }^{6}$ Michael Woolcock, "Why and How Planners Should Take Social Capital Seriously," Journal of the American Planning Association, 70 no.2 (Spring 2004): 183189.

${ }^{7}$ Woolcock, "Social Capital and Economic Development," 159.

${ }^{8}$ Michael Woolcock, "Why and How Planners Should Take Social Capital Seriously," Journal of the American Planning Association, 70 no.2 (Spring 2004): 183189.

${ }^{9}$ Alexis de Tocqueville, Democracy in America, trans. and ed. Harvey C. Mansfield and Delba Winthrop (Chicago: University of Chicago Press, 2000).

${ }^{10}$ Fukuyama, The Great Disruption, 19-20.

${ }^{11}$ Gertrude Himmelfarb, One Nation, Two Cultures, (New York: Vintage Books, 1999), 85-86; The Writings of George Washington, 1744-1799, ed. John C. Fitzpatrick (U.S. Government Printing Office, Washington, D.C., 1940), XXXV, 229, quoted in One Nation, Two Cultures. 
${ }^{12}$ Peter Berger discusses how he and a host of other scholars have retracted their prior claims that modernization necessarily implies secularization. Peter Berger, "Secularism in Retreat," National Interest no. 46 (Winter 1996/97), p. 3-12.

${ }^{13}$ David Chidester, Patterns of Power: Religion and Politics in American Culture (Englewood Cliffs, New Jersey: Prentice Hall, 1998), xiii. Whereas Durkheim emphasized the interdependence of religion and society, Max Weber emphasized the role of religion as an interactive force for social change within society. Max Weber, The Theory of Social and Economic Organization (New York: Free Press, 1947): 358-363

${ }^{14}$ Clifford Geertz, Relgion as a Cultural System: The Interpretation of Cultures, (New York: Basic Books, 1973); Emile Durkheim, The Elementary Forms of Religious Life, trans. Joseph Ward Swain (New York: Free Press, 1965). Thomas Tweed defined religion as a cultural process: "Religions are cultural processes whereby its individuals and groups map, construct, and inhabit worlds of meaning. They involve power as well." Tweed, 12 in Retelling U.S. Religious History (Berkeley: University of California Press, 1997), 14.

${ }^{15}$ Following on Durkheim's work, which emphasized the interdependence of religion and society, Robert Bellah described what he called the "religious dimension" of the political realm, which he termed "Civil Religion." Robert Bellah, "Civil Religion in America," in Beyond Belief: Essays on Religion in a Post-Traditional World, (New York: Harper and Row, 1970), 168-189.

${ }^{16}$ The collective "civic" type of social capital that Putnam describes is what Stepick, Rey and Mahler mean by their term "civic social capital." My conceptual approach to civic social capital differs somewhat from that of Stepick, Rey and Mahler, however, in that they treat civic social capital as something possessed by an individual (similar to Bourdieu and Coleman) and I treat civic social capital as relational and as being possessed by the community (as does Putnam).

${ }^{17}$ Alejandro Portes, "Social Capital: Promise and Pitfalls of its Role in Development," Journal of Latin American Studies 32 (2000) 529-547; Woolcock, "Social Capital and Economic Development; Woolcock, "Why and How Planners Should Take Social Capital Seriously;" Francis Fukuyama, "Social Capital and Development: The Coming Agenda," SAIS Review 23 nol (Winter/Spring 2002): 23-37.

${ }^{18}$ Francis Fukuyama, "Social Capital and Development: The Coming Agenda."

${ }^{19}$ Fukuyama, The Great Disruption, 21.

${ }^{20}$ Lindsay Paterson, "Civil Society and Democratic Renewal," in Baron, Social Capital, 54.

${ }^{21}$ Chidester, Patterns of Power, 5. 
${ }^{22}$ Ibid, 7-8.

${ }^{23}$ Mark Hooghe and Dietlind Stolle have divided social capital into two components, the structural (networks), and attitudinal (trust and reciprocity). Marc Hooghe and Dietlind Stolle, Generating Social Capital: Civil Society and Institutions in Comparative Perspective (New York: Palgrave Macmillan, 2003), 2.

${ }^{24}$ Chidester, Patterns of Power, 8-9.

${ }^{25}$ Putnam, Making Democracy Work; Robert Putnam, Bowling Alone: The Collapse and Revival of American Community. (New York; Simon and Schuster, 2000); Mark S. Granovetter, "The Strength of Weak Ties," American Journal of Sociology 78 (1973): 1360-1380.

${ }^{26} \mathrm{Rev}$. Joseph Wilkinson (pseud.) Interview by author, Perrine Florida, 14 March, 2002. 


\section{Accumulation and Expenditure of Civic Social Capital in the Black Community}

\section{Civic Social Capital Adheres in the Black Church}

The black church has been a vehicle par excellence for the development of civic social capital. From the time of slavery, black churches have been vehicles for amassing and expending black power. It was largely through their churches that enslaved Africans and their descendants constructed an African-American identity, ${ }^{1}$ which allowed for group solidarity enabling survival in America's inhospitable and hostile two-tiered racial political system. At least from the time black slaves were imported to the New World, they looked to their religion not only to explain and understand the spiritual aspect of their lives, but also the secular and political. Sociologist C. Eric Lincoln writes that African-American religion addresses all the needs of its community, both the private and the public. It encompasses two realms, "the 'spiritual' and the 'public,' or the 'private' and the "communal.", C. Eric Lincoln and Lawrence Mamiya identify the "Black Sacred Cosmos" as a world view that is particular to the African-American religious experience. "The black sacred cosmos or the religious world view of African Americans is related both to their African heritage, which envisaged the whole universe as sacred, and to their conversion to Christianity during slavery and its aftermath."3

As Lincoln and Mamiya point out, "the mere fact of black survival in a total system of dehumanization and exclusion is by itself a significant political act. ... After the period of slavery when more political options were possible, the survival tradition among blacks became largely a pre-political condition, but one with political potential." ${ }^{, 4}$ 
The act of worship in a group, which helped Africans attempt to understand and cope with their horrible circumstances in America, therefore constituted what can be considered a political act. From the time the first slaves were brought to America until today, potential political power has been accumulating in the black church. The history of black political power is also in large part the history of movement toward the actualization of this potential through the consolidation by churches of this stored power and the use of it to achieve political change.

The locus of Perrine's identity, both political and religious, has always been situated in it's churches. Through Perrine's hundred year history, the churches have performed functions far beyond what is usually considered the purview of American churches, as Lincoln and Mamiya noted about black churches across America:

Historically, black churches have been the most important and dominant institutional phenomenon in African American communities. The proscriptions of 250 years of slavery, followed by another hundred years of Jim Crow segregation, permitted only the religious enterprise among black people to become a stable, cohesive, and independent social institution. As a consequence, black churches have carried burdens and performed roles and functions beyond their boundaries of spiritual nurture in politics, economics, education, music, and culture. ${ }^{5}$

Because of the long history of black exclusion, black churches functioned, and to some extent continue to function, as an alternative social system. Although there is no monolithic entity called "The Black Church," the term "black church" can be used interchangeably with the black community. As Lincoln maintains: "To understand the power of the Black Church it must first be understood that there is no disjunction between the Black Church and the Black community. The Church is the spiritual face of the Black community, and whether one is a "church member" or not is beside the point in 
any assessment of the importance and meaning of the Black Church." ${ }^{\prime 6}$ The black

leadership of Perrine, including the commissioner, Community Development Corporation head, businessmen, and police officers, are all church members. They speak for and represent their entire community, even including the large numbers of "unchurched" individuals, of whom many lived in the projects and in the crack houses. Blacks have long used their churches, their religion, and religious symbolism to explain to themselves their position in relation to the larger society.

\section{Creating an African-American Identity Through The Use of} American Cultural Images

Peter L. Berger and Thomas Luckmann's theory that "identity is formed by social processes" can be readily applied to the construction of what is generally considered by sociologists writing about the black experience in America as an African-American identity. Until the latter decades of the twentieth century, when much of the political focus of African-Americans shifted, the social process through which blacks of African descent living in America formed their identity was their interaction with America's dominant and racist political system. Blacks of African descent who lived in Perrine (prior to the 1970's when a wave of immigration brought blacks to Perrine from the Caribbean Islands, South America, Africa and other parts of the world), although from different cultural backgrounds, developed an African-American identity, formed as a result of their shared experiences in dealing with a two tiered segregated society. ${ }^{7}$ 
An African American religious identity was fashioned by appropriating key values and symbols from Judeo-Christian theology central to the American understanding of itself. Some of these religious symbols were taken from the Exodus story, and included such themes as the "Promised Land," the "Chosen People", and a Covenant between God and the "Children of Israel." Other religious ideas included those of a sacred destiny, a divine plan, and the millennial beliefs of God's judgement and apocalypse. Much of this religious imagery is knit into the fabric of American political life and is combined with strains of Enlightenment ideals embodied in the Declaration of Independence, stressing equality, justice and natural rights, to form a kind of national culture. ${ }^{8}$ The language of the national culture has been used by individuals and by religious groups in a kind of national discourse on what is important to Americans, what are her central principles and values, and what should be her mission. ${ }^{9}$ Religious groups in America have traditionally defined themselves using the language and symbols of the national culture, adapting them as need be in order to cultivate their own groups' identity. The formation and strengthening of group identities hold the potential for a translation into political action and thus contributes to an increase of any groups' civic social capital. $^{10}$

For much of American history, a white Christian mythology was part of the pattern of power that legitimized white domination over the non-white, non Protestant, non-American "other." According to this myth, America had been singled out from among all the nations to help and save the world. God had led his people from Egypt (Europe) to America, the promised land, to establish a new social order based on liberty, equality and justice and to be a light unto the nations." 
African-American religion would contest this dominant mythology and in doing so, point out its fundamental contradiction. How could America be a model of freedom for the world when she is not truthful to her own ideals? Slavery, the Civil War, and institutional discrimination and exclusion would call into question America's most central commitments. Sociologist Gunnar Myrdal identified this basic religious-political conflict which he termed "the American dilemma," as the conflict between the "high sounding Christian concepts embodied in the American creed as compared to the way Americans really behaved." 12 The Civil Rights movement was one example of an attempt to reawaken the nation to the ideals on which it was founded. Using the language of the national culture, Martin Luther King Jr. invoked the image of God who had acted in Israel's history to declare that he was acting in America's when he said, "God had decided to use Montgomery as the proving ground for the struggle and triumph of freedom and justice in America."13

By using the symbols and imagery that formed the basic vocabulary of the American political discourse, African American religion would provide a framework for black unity in the face of white domination, one that would explain their isolation, exclusion and exploitation by the larger white American society, and point to their future redemption. ${ }^{14}$ One of the first formulations of an African American mythology was the Exodus story by slaves. In this version, Israel no longer referred to white Americans, but to black Africans in America. America was no longer the Promised Land of the Puritans but was transformed instead, into the locus of Egyptian Bondage. Many slaves believed that their Exodus would be from Southern plantations northward, into Canada. The Exodus story provided a way for slaves to understand the dehumanization and injustice of 
their condition. It provided proof that slavery was against God's will and that it would end, although when and how freedom would be attained would rest within God's Providence. Slaves' identification with Israel as God's chosen people provided them with a communal identity as a special, divinely favored people, linked together by a common history and a common destiny. ${ }^{15}$

Another scriptural passage, Psalm 68:31 ("Princes shall come out of Egypt and Ethiopia shall soon stretch forth her hands unto God"), became the source for a number of different interpretations, all in accordance with an American tendency to interpret history in light of a divine plan. According to most of these interpretations, white Christians would eventually be redeemed by the black race. In one version, blacks in America were included in a long line of disciples, apostles and martyrs who, in the name of Jesus, dared to challenge the corruption of power. As in the Christian gospel, salvation would come through the suffering of the oppressed. ${ }^{16}$

A second version centered around the notion that God had permitted, although not approved, the enslavement of Africans so that they could learn about Christianity and then return to Africa to Christianize and civilize the Africans, who had long ago fallen prey to idolatrous practices. As God had brought the Hebrews into the land of Egypt so they could be enslaved and then freed, so too did he plan the slavery of Africans so they could be redeemed. The Promised Land became, in this case, Africa. ${ }^{17}$

Yet another interpretation, one espoused by two late nineteenth century clergymen, Theophilus Gould Steward and James Theodore Holly, held that the darker races would play a central role in the millennial phase of history that the world was then entering. Holly set forth a "divine plan of human redemption" in which there were three 
historic phases of dispensation. The first phase was awarded to the Semitic race which was charged with preserving and writing down the Holy Scriptures. The destruction of the Second Temple ended this phase and the Japethic phase began. This phase was entrusted to European apostles and evangelists whose mission was to spread the Gospel. This period would end in warfare between Christians, ushering in the millennium, a thousand year reign of peace and justice. In the final phase, the Hamitic race would bring to completion the divine plan of human redemption, supplanting the Europeans and Americans who had defamed the gospel. Now, blacks were "the elect among nations," the true arbiters of moral authority, whose divine mission would be to usher in the messianic age. ${ }^{18}$

In the twentieth century, the black redeemer was born again as the "Black Messiah," this time as a redeemer of black people, in Albert Cleage's nationalistic version of the Black Liberation Theology movement. "I believe," declared Cleage, "that the revolutionary spirit of God, embodied in the Black Messiah, is born anew in each generation and that Black Christian Nationalists constitute the living remnant of God's Chosen People in this day, and are charged with responsibility for the Liberation of Black People."19

These examples point to a diverse use of religious and American symbolism in black theologies across America. In some sense, these different formulations suggest the degree of alienation different black groups felt from the dominant national culture, in others, a reproach to America. The nationalistic tendencies of Steward, Holly and Cleage have not found their way into church theologies in Perrine. This is possibly because blacks in Perrine participated and felt included in the functioning of their local 
community and because they formed working relationships with whites which led to trust between the two groups. Theologies among Perrine's churches tended to emphasize an idealized world of a larger Christian fraternity of man, congruent with the ideals of freedom, justice and equality America is supposed to embody. It is more common for churches and homes in Perrine to have "Last Supper" scenes depicting a white Jesus and apostles than a black one. In the late 1990's the Rev. Norman Freeman, youth pastor for Perrine's Sweet Home Missionary Baptist Church delivered a sermon during Black History Month encouraging young people to connect with and develop pride in their heritage which he said included African princes and other royalty in order to become better citizens. ${ }^{20}$

Elsewhere in Miami, especially in Colored Town, where blacks were forced to live in cramped and deteriorating slum conditions, the racial environment was more hostile, with many instances of police brutality and Ku Klux Klan activity, often occurring in tandem. ${ }^{21}$ Religious expression reflected these conditions. In the 1920's many blacks embraced Marcus Garvey's black nationalist movement, the Universal Negro Improvement Association (UNIA). The African Universal Church also found support at this time. Garvey's movement blended the principles of democracy and Christianity which he hoped to embody in an African republic intended to unite the scattered children of Africa around the world. A speaker at the first meeting of the UNIA in 1920 was none other than James Theodore Holly's son, Dr. Alonzo Burgess Holly, a local doctor and resident of Colored Town. He delivered a "fiery" speech on 'the revolutionary activities of his native country of Haiti." ${ }^{22}$ The UNIA had the backing of local churches and lasted until 1928, when charismatic speaker Laura Koffey, claiming to 
be an African princess and preaching black pride, self-help and African repatriation, was murdered while urging members of the UNIA to break from that organization and join her African Universal Church (AUC). Her message was in the prophetic nationalistic tradition: "I am a representative from the Gold Coast of West Africa, seeking the welfare of Africa's children everywhere. God called me out of Africa to come over here and tell you, His people, what He would have you do."23 
${ }^{1}$ As Berger and Luckmann maintain, "Identity is formed by social processes. Once crystallized, it is maintained, or even reshaped by social relations. The social processes involved in both the formation and the maintenance of identity are determined by the social structure." Peter L. Berger and Thomas Luckmann, The Social Construction of Reality: A Treatise in the Sociology of Knowledge (Garden City, New York: Doubleday \& Company, 1966), 159.

${ }^{2}$ C. Eric Lincoln, Race, Religion, and the Continuing American Dilemma (New York: Hill and Wang, 1984, 1999), 230.

${ }^{3} \mathrm{C}$. Eric Lincoln and Lawrence H. Mamiya, The Black Church in the African American Experience (Durham: Duke University Press, 1990), 2; Mechal Sobel developed the concept of the "Black Sacred Cosmos" as a melding of African Religions with Christianity in Trabelin' On: The Slave Journey to an Afro-Baptist Faith (Westport, Connecticut: Greenwood Press, 1979), 3-22.

${ }^{4}$ Lincoln and Mamiya, The Black Church, 201-202; Gayraud Wilmore, Black Religion and Black Radicalism: An Interpretation of the Religious History of AfroAmerican People (Maryknoll, N.Y.: Orbis, 1983); Hans A. Baer and Merrill Singer, African American Religion: Varieties of Protest and Accommodation (Knoxville: The University of Tennessee Press, 2002).

${ }^{5}$ C. Eric Lincoln and Lawrence H. Mamiya, The Black Church in the African American Experience (Durham: Duke University Press, 1990), 92

${ }^{6} \mathrm{C}$. Eric Lincoln, Race, Religion, and the Continuing American Dilemma (New York: Hill and Wang, 1984, 1999), 96.

${ }^{7}$ The more recent black immigrants have entered American society at a later stage of its development. Their struggle is more economic and less racially driven. The cultural patterns they bring with them come from their countries of origin. Many of these immigrants, although they have affiliated in Protestant churches and share similar religious practices as their African-American neighbors, bring with them a distrust of political life. They maintain a negative bias against political involvement, and show a reluctance to join Perrine's original churches in community activities. This point will be developed later in this thesis.

${ }^{8}$ David Chidester, Patterns of Power, pages 81-94 
${ }^{9}$ As Durkheim has suggested, symbols, myths and rituals are central to social cohesion and order. Religious imagery, which has long been a part of the American political structure, has a unifying effect on the different groups that have utilized them. (Emile Durkheim, The Elementary Forms of Religious Life, trans. Joseph Ward Swain (New York: Free Press, 1965); Robert Bellah, Beyond Belief, 168-192.)

${ }^{10}$ Max Weber emphasized the role of religion as an interactive force for social change within society. (Max Weber, The Theory of Social and Economic Organization [New York: Free Press, 1947], 358-363.)

${ }^{11}$ Chidester, Patterns of Power, 22-27; Albert J.Raboteau, A Fire in the Bones: Reflections on African-American Religious History (Boston: Beacon Press, 1995), 59.

${ }^{12}$ Gunnar Myrdal, An American Dilemma: The Negro Problem and Modern Democracy, (New York: Harper \& Row, 1962, orig. ed., 1944).

${ }^{13}$ Albert J. Raboteau, $A$ Fire in the Bones: Reflections on African-American Religious History (Boston, Beacon Press, 1995), 59.

${ }^{14}$ See the following for other examples of some of these interesting and diverse formulations: Raboteau, A Fire in the Bones, pp 17-76; Theophus H. Smith, Conjuring Culture: Biblical Formations of Black America (New York: Oxford University Press, 1994); Chidester, Patterns of Power, pp. 139-164.

${ }^{15}$ Raboteau, A Fire in the Bones, 28-36.

${ }^{16}$ Ibid., 61-62.

${ }^{17}$ Ibid., $45-56$

${ }^{18}$ Raboteau, Fire in the Bones, 55; Holly's "divine plan of human redemption" reversed a popular religious argument that had been used primarily in the Southern States prior to the Civil War to provide justification for slavery. According to the Book of Genesis (1:18-27), the descendants of Ham, were condemned to be "servants of servants," subservient to Ham's brothers Shem and Japheth because Ham had looked at his father Noah as he lay intoxicated. Ham was distinguished as having black skin, and that his descendants would have black skin also was considered a punishment. (Chidester, Patterns of Power, 142.)

${ }^{19}$ In another quotation from Cleage, stating that "Jesus was a nonwhite leader of a nonwhite people struggling for a national liberation against the rule of a white nation, Rome," Cleage continued Holly's formulation of phases of dispensations in alluding to the Japethic phase as the rule of Rome and presumably suggesting that the war between Christians would be fought between whites and blacks. (Cited in Chidester, Patterns of Power, 161) 
${ }^{20}$ Field notes from Sweet Home Missionary Baptist Church 7:45 am service, with Sarah Mahler, 11 February 2001, Perrine, Florida. Partial tape recording.

${ }^{21}$ Paul S. George, "Policing Miami’s Black Community 1896-1930." Florida Historical Quarterly LVII \#4 (1979; Paul S. George, "Colored Town: Miami’s Black Community, 1896-1930." Florida Historical Quarterly 56 (April 1978).

22،"Reports by Bureau Agent Leon E. Howe, Miami, Florida, 7/16/21," Garvey Papers, Volume VI, 514. Quoted in Kip Vought, "Racial Stirrings in Colored Town: The UNIA in Miami during the 1920's," Tequesta: The Journal of the Historical Association of Southern Florida 60 (2000), 59-60. Although Dr. Holly had strong nationalistic sentiments and was supportive of the UNIA, it is not known whether he became a member of this organization.

${ }^{23}$ Quoted in Vought, "Racial Stirrings,"69. 


\section{A History of Perrine}

\section{Prior to 1948: Building Civic Social Capital}

The interactions between Perrine's churches and the dominant white society prior to 1948 show that Perrine had accumulated a substantial reservoir of civic social capital that lay in a latent state. Some of this civic social capital had been produced by way of conflict with the dominant society and some had formed as weak ties by way of relationships with outsiders. The next five sections will provide a closer look at the relationships that developed between blacks and whites in the early years of Perrine's history and show that because both groups shared a commonality of purpose, ties of trust were forged and levels of reciprocity were engendered.

Perrine formed as an agricultural community in 1903, when Henry Flagler, who sought to extend his Florida East Coast Railway southward from Miami, made it the general supply depot for the Key West extension of that line. Perrine was one of many villages that developed alongside the railroad. Miami had just been incorporated as a city seven years earlier in 1896. The arrival of the railroad in Perrine initiated the beginning of a century of rapid growth in population and development in an as yet largely undeveloped and minimally populated South Florida. As they settled in Perrine, Bahamian blacks and American blacks from Northern Florida and Georgia organized churches based on home origin, acts which were as much religious as political.

As with black churches across America, Perrine's churches alternated between two possible approaches open to them in confronting white America - segregation and integration. These strategies preserved their identity and cohesiveness. For most of the 
first half of the twentieth century, these churches were forced to nurture the development of their community in almost complete racial separation. Excluded from the social, economic and political life of Miami, church leaders took care of communal affairs in the absence of county support. Church leaders developed a kind of "invisible government" for their Jim Crow, segregated community that paralleled the official Dade County government. The segregated community's governing body, the "Negro Council," provided the kinds of services one would expect from a municipality or county government: education, a type of police protection, the building and lighting of roads, and garbage removal.

\section{Race Relations}

An examination of race relations during the early years of Perrine's history can help to illuminate the degree of trust that existed between blacks and whites, an indicator of the level of civic social capital within Perrine's black community. Although American society at large, and particularly the Southern political infrastructure, was organized to insure that whites receive the greater portion of goods and services, the demands of frontier life in antebellum South Florida mitigated this bias to some extent. Whites and blacks were forced to cooperate with one another in order to make a living. In this section, three factors that influenced cooperation between the races will be explored: the degree of residential integration between blacks and whites, the types of contact between the two races, and the cultural streams or patterns the respective black groups that settled Perrine brought with them. ${ }^{1}$ 


\section{Partial Residential Segregation}

South Florida was one of America's last frontiers. Until Henry Flagler, the latest in a long line of visionaries aspiring to develop South Florida, decided to bring his railroad to South Florida, the lands in the vicinity of the village of Perrine were wide open to settlers, many of whom squatted on the lands that Congress had once thought "too sickly and sterile" to warrant even the expense of surveying and selling. ${ }^{2}$ In the latest attempt to induce the economic development of Florida, the State offered free land to anyone who would finance construction of a railroad line. Flagler, in securing the rights to extend his railway, had obtained vast amounts of land adjoining the rail line itself. In 1896 he created the Model Land Company (MLC) to manage his expanding real estate holdings in Florida and the Perrine Grant Land Company to sell the valuable farmlands, located along Biscayne Bay, eighteen miles south of Miami and extending six miles west. Flagler's companies played a major part in the settlement and the development--economic, political and social--of South Dade County, and of Perrine. ${ }^{3}$

In platting the village of Perrine, Flagler's Model Land Company implemented the Jim Crow racial practices of racial separation adopted throughout the South in the early twentieth century. ${ }^{4}$ A 1903 Model Land Company plat of Perrine shows a section designated "for Negroes" on the east side of the railroad tracks. ${ }^{5}$ This plat set the general parameters for settlement in the village of Perrine: whites would be permitted exclusive settlement on the east side of the tracks. On the west side of the tracks the land would be split, part reserved for blacks, the rest for whites. Indeed, as MLC sales records show, throughout the first four decades of the century, the blacks and whites lived in close 
proximity on the west side of the tracks. Several large parcels of land were sold to white growers and these growers built living facilities for their workers on part of that land, quarters (one room wooden shacks with shared outhouses) for their black laborers, and separate boarding houses for seasonal workers of both races. Other lots, in the Negro section, were sold to blacks who began to settle in the village itself. Yet, despite this early attempt by the MLC to organize Perrine's social structure according to the norms dictated by Jim Crow practices of the American South, two factors--the continuing biracial settlement of the lands in the vicinity of Perrine, and the nature of farm life itself-resulted in only a partial segregation in Perrine during the first fifty years of its history.

In 1896, although there were only two families squatting on the land that would soon become the village of Perrine, ${ }^{6}$ other land in Perrine's vicinity had already been settled by homesteaders and squatters of both races. This land, referred to as the Perrine Lands, was part of a 28,008 parcel of land granted by Congress in 1838 to horticulturalist Dr. Henry Perrine, one of South Florida's earlier visionaries, for the economic development of South Florida. ${ }^{7}$ Although the terms of the grant were never met, this land was withheld from legal homesteading. In 1896 Flagler's Florida East Coast Railroad ( FEC) became involved in the settlement of a lawsuit against the Perrine heirs over the ownership of the Perrine Lands. As a result of this settlement 2,000 acres went to squatters, (represented by a Squatters Union). Of the remaining 20,000 acres, half went to the Perrine heirs and the other half was divided equally between the Florida Central and Peninsular Railroad and the FEC. ${ }^{8}$ Despite the legal resolution of this long-lasting dispute over the ownership of the Perrine Lands, squatters continued to settle the land in 
the general vicinity of the village of Perrine well into the teens of the $20^{\text {th }}$ century and beyond. $^{9}$

\section{Bahamian and American Blacks, Formation of their Churches, and their Contact with Whites}

The two groups of blacks who settled in Perrine, Bahamians and American blacks from Northern Florida and Georgia, brought two very different cultural patterns with them, and these determined their relationships to the land, their living arrangements, and their interactions with whites. Generally, during Perrine's early history, the Bahamian group lived separately from whites whereas the American blacks had more contact with them. Some in this second group developed positive relationships with whites, leading to substantial levels of trust between the two races.

Of the first black settlers in Perrine, the Bahamian group seemed to be on the whole more independent, self-sufficient, and enterprising than the Americans.

Bahamians had a long history of dwelling in South Florida. ${ }^{10}$ As one Bahamian writer observed, these early visitors regarded Florida "much as another island of the Bahamas."11 They came to south Dade for many of the same reasons northern whites and Europeans did, to take advantage of South Florida's economic opportunities. Bahamians lived as squatters, claiming the land by cutting down pine trees, digging up the rocks, building houses, and farming on it. An area just north of the village of Perrine ${ }^{12}$ was referred to as "Nassau Quarters," where a number of Perrine's Bahamian families settled. Some Bahamians employed their own (black) laborers, whom they housed in quarters 
they constructed on their properties. They knew how to farm the poor rocky land of South Dade because of the similarities to the land in the Bahamas. ${ }^{13}$ One Bahamian who was born in Nassau Quarters described this land as "nothin' but trees and rocks, sharp rocks and bushes. ... I don't know how we survived running over these rock with our bare feet. But we learned how to. . rock just as sharp as razors."14 An American black woman who grew up in quarters on a white grower's farm remarked in amazement that the Bahamians, whom she referred to as "Saws," short for "Nassau's," "grew tomatoes in the rocks."15

The Bahamians also fished in the bay and cut down trees from the pine forests that covered much of the area. ${ }^{16}$ They sold some wood to the telephone company for poles. Other wood they made into lumber for which they used to build buildings and for woodworking. Bahamians were known as expert carpenters and builders. One Bahamian resident related that when he was a boy he helped his father cut down pine trees to make charcoal which they sold to hotels on Miami Beach. ${ }^{17}$ Bahamians built their homes and churches, scarified (cleared the rock off the land to prepare it for building roads) the land, grew and imported their own food from the Bahamas, and operated their own stores.

Other Bahamians came to Perrine to work as employees, some as seasonal laborers for white growers ${ }^{18}$ or in the local sawmill plant. Perrine's first church was organized by Bahamians at the Ramsey-McCrimmon saw mill on the Tropico Lumber Company grounds in 1912. The Tropico Lumber Company donated the building for their church. ${ }^{19}$ Some of the most prominent leaders and families of the Perrine community founded this church, and the membership increased steadily throughout the first half of the century with newly arriving Bahamians. The founders included both employees of 
the saw mill and independent blacks. Many of the workers who lived in quarters provided by their employers bought their own land when they could and joined the first group of Bahamians in Nassau Quarters.

Perrine's first Holiness church was formed in 1919 by a Bahamian, Robert Bruce Ingraham, who lived in Nassau Quarters on a thirty-five acre parcel of land and employed his own workers. ${ }^{20}$ Robert Bruce Ingraham was a prominent communal leader in Perrine who had helped found Hurst Chapel. ${ }^{21}$ In the 1930 's, as more people, black and white, moved to Perrine looking for relief from the Depression. At the same time the Bahamians living in Nassau Quarters began to sell their land and move into the "Negro" section of Perrine.

Most blacks from Northern Florida and Georgia came to Perrine to work for the large white growers, first as seasonal laborers, and then permanently. They tended to be less independent than the Bahamians, willing to endure the often demeaning living conditions and the sometimes coercive practices of their employers, and less driven to own their own homes. One large grower, Robert Kerr, employed many blacks, mostly Americans, on his farm. In the 1920's he provided a hut to his workers for church services. They organized two churches, one Methodist and another Baptist, that met on alternate Sundays in this building. ${ }^{22}$ The fourth of the main-line Historic Churches of Perrine, Mt. Moriah Missionary Baptist Church, was located in grower Peter's quarters, founded in 1919, also by American Blacks.

An exception to the generalization that American blacks tended to be less independent and enterprising than Bahamians was Alfred "Doc" Coleman. Coleman was from Georgia and came to Perrine in the late 1920's by way of Titusville, Florida where 
he had formed seven churches. He established Perrine's second Holiness Church, "First Born Church." Coleman became one of Perrine's most important communal leaders. ${ }^{23}$ Most of the laborers on these large farms had limited contact with their white employers. Sometimes what little contact they did have was negative. One Bahamian woman related how some of the practices by white grower Robert Kerr were unacceptable to her parents. Her mother told her that in the 1920's Kerr tried to force his workers to buy their groceries in his commissary, that he would lock them into a fenced yard at night to make sure they would be sober and ready to work the next day, and that he even kept a dog with gold teeth to prevent workers from escaping. The American blacks seemed willing to comply with these restrictions, but her mother, pregnant and unafraid of Kerr, climbed over the fence one night to protest what she saw as slave-like conditions. The next day she and her husband moved to another farm, four miles north of Perrine to work for a Swedish employer who treated his workers with more respect. ${ }^{24}$ On the whole, her attitude was reflective of those of other Bahamians. Oppressive and demeaning conditions were generally not acceptable to Bahamians, who were not accustomed to thinking of themselves as second-class citizens or of depending on whites for their livelihood. They were used to owning their own farms in the Bahamas and arrived in Perrine intending to replicate this arrangement.

Although many American blacks worked as common laborers on the farms, picking and packing tomatoes, there were some who formed close relationships with their employers. These blacks held responsible positions as foremen, migrators, ${ }^{25}$ property caretakers, rent-collectors, housekeepers and nannies. Bishop Ingraham described the special relationships Robert Kerr had with several black workers on whom he depended, 
and for whom he developed a special affection: "I. C. Davis, he was his handyman, worked around his house and things like that. He (Kerr) had close people working for him. . I don't know what you call them but he loved them. They were closer to him than anybody else. I.. C. Davis did all this, cleaned up his yard, cleaned up his cars, and he'd be there. And he never went to the farm. He was there all the time, around the house."26 Many blacks from this group assumed leadership roles in their churches. One church leader, Ben Shavis, was also the president of the Negro Council and another of Robert Kerr's trusted right-hand men.

Initially it was the American blacks who developed closer ties to whites, through the joint effort of working the farms together. These relationships benefitted both blacks and whites. Building trust between these two groups increased the ability of whites to depend on blacks to help run their farms. It led whites to lend their support to black institutions. For example, Robert Kerr, was so appreciative of Ben Shavis that he deeded to Shavis the church building that Shavis's Methodist Church used. Growers Peters and Berkhart donated property on which the black school was built. ${ }^{27}$ Grower Cecil Barber willed rent-collector and chauffeur Vester Jefferson enough money with which she could buy a house and retire comfortably. ${ }^{28}$ Another trust-building activity between blacks and whites involved the extending of credit by white businesses to blacks. Because Bahamian businesses were so small they were not in a position to extend credit. American blacks had to seek credit from white businesses, a practice that increased contact and good will between the races. ${ }^{29}$

During the first fifty years of Perrine's history, the Bahamian and the American groups maintained their cultural distinctiveness to the extent that co-mingling between 
the two groups was minimized. Socially Bahamian and American blacks maintained their separation through membership in their respective churches. Bahamians tended to be more protective of their children than Americans, keeping them at home where they could be closely supervised. Bishop Ingraham recalls that when he was a boy he was closely watched by Bahamian adults: "It took the neighborhood to raise the children in those days. During those days, the Georgia people didn't bother too much. But boy if I walk down the street and there was a Nassau fellow, Mr. Ferguson or Mr. Moss keep us straight as an arrow." The term "Saws," short for "Nassau's" given to Bahamians by American blacks, was a pejorative one, indicating that Americans perceived of Bahamians as feeling superior to them, that they "thought they owned Perrine." Consequently American blacks were told to "stay away from those Saws." Intermarriage between the two groups was strongly discouraged. ${ }^{30}$

One socially acceptable form of co-mingling between the two groups was through church fellow-shipping, where churches would invite individuals, choirs, or other churches to worship with them. Fannie Mae Williams, of Mt. Sinai Baptist Church, in Kerr's Quarters, used to worship in her own church, Mt. Sinai Baptist Church in Kerr's Quarters, and then, when the service ended she would go to Elder Ingraham's Holiness Church "until four o'clock in the morning" to have church with the "Saws." She explained, "I loved to see him shout.... We all mixing in together after we leave our church. It's always a scene going on over in Ingraham's church. And everybody be shouting and having a good time."31 


\section{Three Cultural Streams}

The attitudinal differences between American and Bahamian blacks reflected cultural patterns that these groups brought with them from their places of origin. Race relations between blacks and whites in these two countries differed significantly. In America, slavery and then sharecropping were so closely tied to the Southern economy that American blacks had lived for generations under subjugation to white landowners, often by use of terror and intimidation in a two-tiered class structure.

In the Bahamas, well before slavery had been formally abolished in 1834 , conditions for "free blacks and persons of color" were more favorable than in America, in part because of the failure of the plantation system in the Bahamas (the land was poorer in the Bahamas and the economy was not as dependent on slavery as in America), but also because of the strong abolitionist attitudes in the British Parliament. A distinctly Bahamian way of life had developed by 1784 from the confluence of British, African, and American social practices including a hierarchical system ranking different classifications of Africans and the existence of more socially sanctioned areas of intersections with whites (including legal commingling between the races). ${ }^{32}$

Bahamians arriving in America were startled by the racist attitudes and discrimination they found there. ${ }^{33}$ Bishop Ingraham remembered a game he played with his sisters and brothers as a child. "We'd go up by the road, and cars used to come by and we used to play a game at the end. We had to do something. We had to do something to break the barriers of communication. And so we said, all right, who's driving this car? And you listen, and you listen, and you listen, and you listen. There, a 
white man. All right. Open your eyes. You won." Then, "And here comes another one; dum, dum, dum, dum, dum, dum, dum. All right. Whose driving that car? A black man. . Always knew who was driving that car because of how it sound." Ingraham said he changed the wording of the Pledge of Allegiance when he recited it at school to reflect the inequality he felt. "I used to, from the time I started school, the Pledge of Allegiance. I pledge allegiance to the flag of the United States of America and to the Republic for which it stands, one nation under God, indivisible, and justice for all the white folks.... Why? It was just there that we had no, we didn't have a good car, we didn't have a good house, we didn't have good shoes, we didn't have good clothes. We didn't have anything. They had everything., ${ }^{34}$

Because Bahamian blacks had associated according to the social strata to which they had been assigned in the many-tiered system of the Bahamas, they brought this pattern of association with them to Perrine. Bahamians arriving in Perrine were not so interested in integrating into the two-tiered racial structure they found in America. In Perrine they easily replicated the more varied arrangement of the Bahamas. Segregation, as a response to America's racially-based social structure would serve the Bahamians in Perrine well over the first fifty years of its history.

Churches in the Bahamas reflected the Bahamian societal class stratification, with its upper echelons, the "free blacks/colored" and "persons of color," tending to join Anglican churches, and the lower strata, the "liberated Africans" and "slaves," drawn to Baptist and Methodist churches. Separation between the classes was maintained through their churches and by their schools, which were located in the churches. Doctrinal and organizational differences between the denominations re-enforced their separation. The 
issue of when to baptize, at birth as the Anglicans held, or when persons are old enough to know its significance, as the Baptists practiced, bespoke of a larger controversy within Christianity, harkening back to the Protestant Reformation. Baptist churches, with their congregational structure, served to distance its members from British/Anglican authority. ${ }^{35}$

It is notable that, although other Bahamians who had already settled in South Florida - in Key West, Coconut Grove, and Miami - formed Episcopal churches in those communities, Bahamians in Perrine did not, neither in Perrine's early history, nor in subsequent years. ${ }^{36}$ Presumably Bahamians who settled in Perrine had not been members in the Anglican Church in their home country and so did not form churches from this denomination in Perrine. But was there a religious-political significance to the lack of Episcopal Churches in Perrine? Robert Bruce Ingraham's son, Joseph, who would eventually form a Holiness Church in Perrine as his father did, suggested that Bahamians came to America for much of the same reasons the Puritans did: "I believe that when they came over they were seeking something different," than "the tradition of the Episcopal they were all fleeing." He spoke of the sacred nature of the Bahamian journey to American when he said that Bahamians came to America "seeking better religion, better relationship with their God" because "they didn't have people over there in the older country to serve God." ${ }^{37}$ Joseph Ingraham explained that his father, in establishing a Holiness Church in Perrine, eventually found the "real salvation" that Bahamians had been looking for but had not been able to find in the Bahamas. His father's PentecostalHoliness church was part of a larger movement within Christianity that sought to 
challenge what they viewed as corrupt forms of Christianity, and which, according to Ingraham, the Catholic and Anglican state churches exemplified. ${ }^{38}$

Pentecostal church member Shirley Green, explained this last point, expressing the Pentecostal-Holiness view that traces their movement to the day of Pentecost described in Acts. As Green relates, Jesus, at his death, told his disciples to go to Jerusalem and wait for a comforter. Ten days later, at the time of the Pentecost, the "Holy Spirit" lit on each disciple, anointing them with the "Spirit of God." These original "Pentecostals" were persecuted (the earliest persecutor being the Apostle Paul himself) and the religion went underground, organizing as small churches, or "house churches." As Jesus gathered his original apostles from the ignorant and the poor, the Pentecostals would draw their membership from the lower economic strata as well. A remnant of these original Christians somehow survived throughout the centuries; their house churches would divide and spread in response to repeated persecutions by the false and corrupt Catholic Church that gained ascendancy while promulgating unspeakable horrors (i.e. the Crusades, wars against Christians, remaining silent in the face of the "Jewish Holocaust"). The Pentecostal-Holiness movement is a continuation of the original Christian religion that has been gaining momentum as many in the world recognize that the world is entering the "End of Time," as prophesied in the Book of Revelations when Jesus said, "In the Latter Days, I will pour out my spirit upon all flesh, your sons and your daughters." 39 Green explained that the "real salvation," that the Bahamians in Perrine had come to America to find was the "Holy Spirit" that Jesus had promised to pour out on mankind when they agreed to do his bidding. ${ }^{40}$ 
In America, the Holiness movement is associated with renewal and reform. ${ }^{41}$ It began in an attempt to reassert and extend pietistic values within the Church and the larger culture. ${ }^{42}$ In the early years of Perrine's history, Holiness churches functioned in a similar way with regard to the black community. Pentecostals criticized (Baptist and Methodist) church members whom they held "drank, fornicated and caroused" on Friday and Saturday nights, only to be in church on Sunday mornings to repent. Perrine's Pentecostal churches maintained a tight authoritarian structure, with dress codes, conduct, and strict adherence to moral strictures enforced by the church leaders. PentecostalHoliness movement would become an important feature of Perrine's religio-political identity, playing a large role in Perrine's struggles in the later decades of the twentieth century.

A third cultural stream that came to influence the social, economic and political development of Perrine was represented by the prominent Shackelford family. James Shackelford moved to Perrine sometime in the late 1920's or early 1930's. His father, Louis, was a Cherokee Indian, and was born on a reservation in Oklahoma, where his father and his runaway slave wife were deported during one of the Seminole Wars. After the Civil War he returned to Florida, the land of his father's birth. James built houses, quarters, and a church building on the property that he bought in Perrine from the Model Land Company. He brought his parents and some of his brothers to Perrine. ${ }^{43}$ It is unknown whether the church he had built had a membership, as he himself was a member of the Bahamian Church, Hurst Chapel. He and his family were important communal leaders in Perrine, building roads, donating land for the public school, renting out his church building and holding meetings of the Masons in his garage. ${ }^{44}$ Semimole Indian 
cultural heritage in the area may also have come by way of Bahamians, some of whom like Mrs. Ingraham came from Andros Island, where Black Seminoles escaping from Florida fled in the 1820 's. $^{45}$

The contribution of these different cultural streams--Bahamian black, American black, and American Indian-- influenced the racial attitudes and behaviors of blacks and whites in Perrine and their interactions with each other. The Bahamian contribution toward racial attitudes and behavior stemmed from their self-sufficiency, independentmindedness, and intolerance of unfair social and political systems. The Seminole heritage, like the Bahamian, combined an independent, self-sufficient and enterprising spirit with a willingness to fight when necessary. For their part, American blacks developed personal ties to whites that engendered loyalties between the two groups. On the negative side, many American blacks developed a sense of hopelessness because of problems associated with breakdown of the family because of disruptions in family life, legacies of their slavery experiences in the American South. The personal ties American blacks formed with whites, however, led to a certain level trust and cooperation between Perrine's whites and blacks.

\section{Generation of Trust and Reciprocity}

Overall, there was a general level of trust that developed between the races that contributed to a willingness to cooperate, even if cooperation meant perpetuating a system of inequality. Some instances of this cooperation have already been cited. On an institutional level, the Model Land Company policies reflected a vision for the creation of 
a well-ordered, "good" and sound society, one that, in promoting the well-being and welfare of its community members, would also benefit the company's business interests. The MLC took care to develop Perrine (and the other villages along the southern railroad extension) in a way to enhance their attractiveness and desirability to new settlers, always keeping a close eye on profits to the company. Flagler once remarked, "Every new settler is worth $\$ 300$ a year to me. He has to bring in everything he uses and send out everything he produces over my railroad., 46

Correspondence between the MLC land agents and presidents reveal that every real estate transaction was assessed for its long-range profitability, and no sale was approved if it would not contribute to the company's vision. Company policy assessed the profitability of every real estate transaction according to the likelihood that buyers could continue to make property payments. The MLC, for example, decided against selling land for a boarding house in Perrine in 1911, unsure as to whether there would be enough business to sustain it, but when increased sales of property indicated that the economy was improving, they approved the donation of two lots for a hotel in 1914 as long as a building be constructed costing "not less than $\$ 5,000$ is built on them." MLC was also closely involved in the plans to build a white school in Perrine, as it was in drainage issues and road construction. It interceded in local politics to lower taxes on its larger, more valuable properties so farmers could afford to buy land and make mortgage payments.

The policies of the MLC reflected company beliefs about the importance of religious institutions to the proper functioning of society and enabled whites and blacks to acquire land on which to build their churches. When a group of Bahamians from Pine 
Grovers Church wished to buy land in Perrine's Negro section for a church, land agent Frederick S. Morse wrote to MLC president, James E. Ingraham, "We think it advisable to give them all the encouragement we can in order to get a good colored settlement here as their labor is needed in the vicinity of Perrine."48 Ingraham responded by donating the lot outright, again, stressing the importance of beautification standards by insisting that his architect design the building, "in order to have something that will be an attraction to the place."

At various times crop failures due to droughts and excessive rains, tariff laws and poor markets prevented both blacks and whites from making payments on their properties. A perusal of decades of MLC records show an even-handed, compassionate assessment of each petition for late payment. Correspondence between the land agents and MLC executives noted racial differences of the various petitioners but did not act with prejudice in considering their decisions. Because blacks and whites were considered essential to MLC profits, leniencies were granted to both races, if petitioners were judged to be acting in good faith, in order to prevent foreclosures on properties.

Notwithstanding the MLC's exercise of power in favor of its business interests and its tacit endorsement of the social codes that included a two-tiered racial structure, it must be noted that company attitudes towards blacks, as reflected by the policies discussed in the many letters between MLC land agents and presidents and in their general tone, demonstrated a respect and consideration for blacks and for their expressed interests. This attitude is reflected in a letter written by MLC land agent Frederick S. Morse to its secretary, Sidney Harrison, concerning the purchase of a lot by Perrine's AME Church (then called Pine Grovers). In a letter dated April 18, 1919, Morse writes: 
Mr. S.H. Whitus, pastor of the African Methodist Episcopal Church, has asked us a price on Lot 12 of Block 10 Perrine, Fla. I quoted him a price of $\$ 120.00$ and when he asked me what terms we would sell on, I asked him what was the best cash offer he could make and he replied $\$ 75.00$. Shall we let him have this lot for $\$ 75.00$ or do[es] the Company want to consider the deal as a matter of charity and give them the lot? ${ }^{49}$

By the 1940 's, as more people began moving into south Dade County and more properties began to be bought and developed for housing, certain racial tensions began to threaten the relationships between Perrine's blacks and whites because of new county zoning decisions that valued properties along racial lines. Suddenly blacks and whites were no longer collaborators but were pitted against each other as the racially motivated public policy of "redlining" threatened to devalue land owned by blacks or land near that owned by blacks. ${ }^{50}$ MLC correspondence reveals that by 1943 blacks did not want to buy land in Perrine's colored section that was close to white property because they were being threatened by whites. ${ }^{51}$ This issue will be treated more thoroughly in a later section, but at this point it should be noted that it was forces outside Perrine's social structure, not within, that began to undermine the bonds of trust and reciprocity between blacks and whites in Perrine, those bonds which constitute the building blocks of civic social capital. As building increased during the 1940's and 1950's, racial tensions would increase between whites and blacks, including increased Ku Klux Klan activity, as some whites would attempt to re-enforce the "color line" of a segregated Dade County and secure white-only residential areas. ${ }^{52}$ 


\section{Generation of Civic Social Capital}

During Perrine's first fifty years, as it moved from a rural outpost into a town of 3500 (by 1948), a certain degree of trust and reciprocity had developed between the races, albeit within the confines of a segregated society. Trust and reciprocity are important gauges of civic social capital. But, as Portes and Paterson have suggested, it is during points of sharp conflict that (civic) social capital may be created. David Chidester's theory that "political power may be generated by the competition between mutually exclusive social interests" suggests that it was the interaction between this black community and the dominant white society that has contributed to the production of civic social capital. ${ }^{53}$ This has been true in Perrine, especially during the first half of the twentieth century.

\section{Zones of Conflict: Generation of Civic Social Capital in the Black Church Through Conflict and Competition with the Dominant Society}

Numerous zones of conflict throughout the first fifty years of Perrine's history, particularly those between its churches and the dominant white system, have led to the generation of civic social capital in Perrine's black churches. In order for conflict to

produce civic social capital, networks must form. A social group forms networks by way of bridging interactions with outside groups. The ability to build cooperation between groups determines the amount of civic social capital a group will possess. This section 
will illustrate several types of networks Perrine's churches built, ranging from associations with other blacks to ones with whites.

\section{Education for Black Children}

One example involves the conflict between the Perrine community and the Dade County school board over the education of Perrine's black children in the early years of the century. This struggle was undertaken in the context of the larger struggle in America concerning the rights and privileges that should be afforded blacks in a society dominated by whites. Despite the apparent resolution of this dispute in 1896 by the landmark United States Supreme Court case of Plessy v. Ferguson that mandated equal but separate treatment for blacks and whites, it soon became evident to blacks in south Dade County that the Dade County School Board was ignoring the mandate of the Supreme Court and that the treatment of white and black children was far from balanced.

Dade County Public School Regulations required that Dade County finance a school if there were ten children in any given area. A look at the School Board's actual policies from its inception show that it had a long history of disregarding its own regulations when it came to providing schools for black children as the following brief history shows. The first known public school in Dade County, a white school, opened in 1886 in the Lake Worth area. A year later, white schools were opened in Lemon City, Coconut Grove and Elliott's Key. But it was not for another seven years, in 1893, that a school for black students opened in the Lake Worth area, and another nine years after the 
white school in Coconut Grove opened that the School Board gave funds to Coconut Grove's first school for black children.

In 1896, the year Miami was incorporated, and when its population had grown from zero to 2000 in one year, the School Board did contribute to a white school and a black school there. The same year the School Board also funded a white school at Cutler, near Perrine, enrolling fourteen children. It soon began providing teachers and assisting with the building or acquisition of other white schools during the early years of the twentieth century in the villages of southern Dade County, including ones in Silver Palm and Princeton. No schools for black children south of Coconut Grove would open until 1914 , however. ${ }^{54}$

Perrine's first school, a one room building, was opened by the Dade County School Board in1909 for white children. By 1914 the School Board had expanded it into a two-room school with an additional teacher. By 1916, the Board had provided the funds for an entire new white school. ${ }^{55}$

Schooling for black children in Perrine, however, showed that blacks were not given the educational opportunities afforded to white children. First disregarding the ten children rule, and then offering disproportionately lower amounts of funding for black schools, the Dade County School Board willfully ignored and neglected the education of black children. Although the exact numbers of blacks and whites living in Perrine and the surrounding area during the first two decades of the twentieth century is unknown, it can be assumed that there were more blacks than whites because the many workers employed on the large farms were blacks. At any rate, by 1920 there were enough blacks living in Perrine itself to comprise three churches. Nevertheless, blacks did not secure a 
public school until 1914, and this school was not in Perrine but four miles to the south in Goulds, in a church which black farmers Arthur and Polly Mays had helped to organize. ${ }^{56}$ Perrine's children walked four miles each way to attend this school. The Mays transported children from the neighboring villages of Modello, Naranja and Princeton so they could attend. By 1918 there were eighty two black children attending the Mt. Pleasant School in Goulds, with one teacher! ${ }^{57}$

Church leaders from Perrine petitioned the School Board for their own school. They finally succeeded in obtaining one from the county in 1920 , on the condition that a church be provided for use as a classroom. Still, it was another two years before a teacher was hired, and even then, the Perrine community had to supplement the teacher's salary with free room and board. ${ }^{58}$ Nonetheless, the new school represented an achievement for the Perrine community and its church leaders, and indicated an accumulation of influence. Perrine's churches expended significant energy wrestling with the broader forces of the dominant society, in particular, the School Board. Their success in obtaining a school, which can be seen as an example of conflict with the larger, dominant society, added to their influence and elicited further accumulation of civic social capital.

\section{The Negro Council}

A second example is in the context of a growing demand for municipal services by farmers in South Dade as the population increased during the 1930's and 1940's and farmers in southern Dade County competed for municipal services from an overburdened 
county government. ${ }^{59}$ Residents of Perrine formed two governing councils, one white, the other black, to try to procure needed municipal services from an overburdened county government. The "Negro Council" represented the interests of Perrine's black community. It effectively raised money from the community to install street lights, to provide for garbage collection, and to press to have roads scarified and paved. ${ }^{60}$ A partial list of Negro Council members show that they were pastors, deacons and lay leaders of Perrine's churches, successors of the church leaders who organized Perrine's first school. Some worked on the large farms of white growers, holding responsible positions. Others, like Robert Ingraham and Doc Coleman, Elders (pastors) of Holiness churches, were selfemployed. Members of the Negro Council included the aforementioned Elders, Ben Shavis, Don L. Williams (worked for grower Robert Kerr as a migrator), Herbert Agers (worked for Robert Kerr) and James and Neal Schackelford. ${ }^{61}$

The Negro Council was effective in getting the county to build roads in their neighborhood by enlisting the help of the Model Land Company and County Commissioner, J. Lamar Paxson, who had been grower Robert Kerr's business partner, and now represented District No. 4, South Miami. In 1940, during a time when the county was unlikely to allocate monies to improve "Colored Areas," 62 the Model Land Company arranged a deal with Paxson to have the county scarify and pave roads in the Negro Section of Perrine in exchange for the use of unsold MLC lots as a runway for crop-dusting planes. Several letters between the MLC land agents and vice-president indicate that Commissioner Paxson agreed to construct the roads, but that he preferred to bypass the Board of County Commissioners and to scarify the roads a little at a time while he was doing other county-approved road work. This bi-racial cooperation 
occurred in a way that benefited all parties; the black community obtained roads, the lots in the Negro section became more desirable, thereby increasing the profit potential for the MLC; local growers protected their crops from the onset of a new disease that threatened to ruin their livelihood; and the county got the free use of land. ${ }^{63}$ At the same time, a possible confrontation with the Board of County Commissioners over a racially sensitive decision was circumvented by Paxson, who agreed to scarify the roads off the record. ${ }^{64}$ The Negro Council's success in obtaining roads demonstrates that the black community had accumulated a considerable quantity of civic social capital and that they were able to enlist the help of whites, by way of bridging interactions, in their struggles with the dominant system to obtain goods and services ordinarily denied to blacks. This example also demonstrates that all the parties involved - Perrine's black community, the MLC, the white farmers, the County Commissioner, and even the County itself-received benefits from their cooperation. This in turn increased the levels of trust between the groups.

Black Freemasons as Police

Although many in Perrine's local white community were sympathetic with blacks regarding the deficiencies in government services afforded them, in many respects their hands were tied, as the following example of the confrontation between Perrine's black community and threats of racial violence by the Ku Klux Klan demonstrates.

Perrine had no police department until 1948, the year it was incorporated. According to oral histories, one of the first orders of business was to hire a police force, as Perrine depended on the State Police, which lacked the resources to fully service the 
community. The newly incorporated town hired a white officer and then later that year, two black policemen. ${ }^{65}$ Until then, black Perrine had no formal way to defend itself from the Ku Klux Klan. It is uncertain whether the eventual presence of a few policemen in Perrine would even have been sufficient to protect Perrine's black citizens, given the racial climate elsewhere in Dade County, where the police were notably absent during Klan activities. In fact, there were allegations that a significant number in the police department held Klan memberships and participated in cross burnings, demonstrations, and violence. Miami police chief $H$. Leslie Quigg himself refused to deny a rumor that he was a Klan member. ${ }^{66}$

Perrine's black Freemason chapter acted to combat Ku Klux Klan activity, performing as a type of de facto black police department. ${ }^{67}$ Many of Perrine's Negro Council members also belonged to the Masons. These members represented churches in Perrine and in neighboring Goulds. Their meetings were held in Neil Shackelford's garage. His son, James, remembered these meetings, as he did the Klan riding through the neighborhood at night in their hoods, threatening to burn down houses. The Masons, he said, were armed and ready to defend their community: "They fought for them. They come by riding, you know, with their heads stuck out from under. The next morning. They wouldn't do anything. So we didn't do anything either." ${ }^{, 68}$ It was widely believed that most of the Klan who rode through Perrine were not from Perrine, but from the farms in the Redlands, farther South.

The black Masons functioned in many ways like the black church in that they represented the black community and dealt with civic and spiritual matters. Their parades through Perrine were spectacular events, involving music, pomp and 
circumstance, and attracting the entire community. One member, Archie Finkley, described the Freemasons as "a religious organization. It's supposed to take care of the down and out, the troubled, the blind, the crippled. ${ }^{969}$ Indeed, one of the central communal services provided by the Eastern Stars, the woman's Masonic branch, was a burial society, providing funeral services for people too poor to afford them. The Eastern Star had their own building where they held dinners, parties and "turnouts" (parades). They also helped provide assistance for churches in need. ${ }^{70}$

Freemasonry drew from both Biblical sources and European Enlightenment ideals. A Masonic edition of the Christian Bible owned by Archie Finkley states in its introduction that Masonry is "Biblica in origain [sic] and in development" and that its "fundamental principles" include "Liberty, Equality, and Fraternity" and the "Fatherhood of God and the Brotherhood of Man." Furthermore, it states that "morality and virtue are the essentials of true manhood" and that "Civil and religious liberty must be paramount." 71 The Masonic ideals of fraternity and equality with all men under God were appealing to blacks in Perrine, who awaited a time, perhaps millennial, when the hypocrisies of white Christian churches would be abandoned and all men would be joined together in a bond of brotherhood. Until then, Freemasonry was a way blacks could share membership, albeit secretly, with a larger fraternity of enlightened men of all races, men who shared their ideals of a free and equal society, and who included among others, presidents of the United States. ${ }^{72}$ James Shackelford related an incident to show how membership in this fraternity operated within the strict racial strictures imposed by Jim Crow society: "I remember. . . when, we went up, going to West Florida, Chipley. It's about 100 miles on the other side of Tallahassee....We was going up there. Going to 
my aunt's funeral. That was 1950. I was twelve. . . And my father ran out of gas. This was late at night. And a gas truck come along. Put that Mason sign on. He stopped and gave him gas. He was white. This was in fifty. It was, you know, most lawyers, judges, they all respect you."

One aspect of policing that Perrine's Masons performed was not endorsed by all community members. According to Bishop Joseph Ingraham, this practice was widespread in the Bahamas, but also practiced to a more limited extent in Perrine. Taken from an [incorrect] reading of the Bible, to set up cities of refuge for any man who takes another man's life, some Masons hid people who had committed murder and sometimes they sent them back to the Bahamas. ${ }^{74}$ Ingraham explained: "That's written in the Scripture. . . that if any man would kill another man, then God commanded Moses to build houses of refuge and [they] would take him and they would hide him and this man's family would not be avenged.",75

Bishop Joseph Ingraham, an ardent supporter of the United States justice system, broke with this faction of Perrine's black community, saying that although his father, Robert Bruce, was a thirty second degree Mason, he himself could not be involved in an activity that would not bring a killer to justice and therefore declined membership in that organization: "I had a conflict. I never could be a Mason. Never had. I was always asked but I have nothing to be secret about. . . . Take a person that committed a crime and not let him do the time for committing the crime? I couldn't be part of it. . Because if somebody kills somebody you take him to jail. You don't take him away from jail." Bishop Ingraham's objection to this Masonic practice was based on the belief that cities of refuge were one of God's commandments that applied to the Israelites but no longer 
applied to Christians because "after Christ came, the Dispensation, the Old Testament was dissolved."

Blacks in Perrine used the Masons to confront racism. In a sense, the Masons were an invisible black institution that provided police protection against an invisible white institution, the Ku Klux Klan. But on a higher level, Perrine's Masons were connected to all of mankind, through the invisible fraternal bond black Freemasons shared with whites world-wide. Black Freemasons trusted whites because they trusted that God intended all men to be brothers under one God, and that as much as they could their white fraternal brothers would work behind the scenes to try to achieve the world God intended. ${ }^{76}$ This association empowered them. Civic social capital was produced by way of black conflict with the larger white racist society and buttressed by the transcendent ties bridging blacks and whites in an imagined realm. On the other hand, the Mason's secondary function, that of hiding people who committed crimes, indicates that a faction of Perrine's population distrusted that the government would administer justice fairly. Bishop Ingraham's refusal to participate in this popular black institution reflects his inherent trust in the American system, however flawed.

The use of religious, or quasi-religious institutions to confront racism was not new to blacks in southern Florida. In the 1920's black nationalistic forms of religious expression found their way into black life. One of these institutions, active between 1920 and 1928 was Marcus Garvey's Universal Negro Improvement Association (UNIA). The UNIA functioned, as did the Masons in Perrine, as a quasi-religious organization. It's meetings opened with prayer and a scripture reading. The organization provided social services, held social events (dances, parties, fund raisers and celebrations), and parades 
(its uniformed branch, the African Black Legion wore full military dress and carried rifles). A local chapter was formed in Colored Town on November 14, 1920. Its membership grew to one thousand, mostly Bahamian, and extended to Coconut Grove and Homestead. The UNIA was supported by many of the local black clergy. Its focus was to provide unity, to improve the slum conditions of Colored Town and to provide protection to blacks who suffered periodic episodes of police brutality. In 1921 Miami's existing racial tensions were augmented by the arrival of the Ku Klux Klan with a parade of 200 men wearing traditional hoods and robes. Presumably residents of Colored Town prepared themselves for a possible show-down because, according to an FBI report, agents apprehended a cache of arms and ammunition. Marcus Garvey himself, concerned about KKK violence toward the UNIA met with Klan leader, Edward Young Clarke in 1922. Apparently they agreed on the importance of "racial purity" - that the United States is a white man's country and that Africa should be reserved for Africans. No violence by the Klan against the UNIA was reported after this meeting. ${ }^{77}$

Black Christian nationalism was evinced by at least two other individuals in Miami during the 1920 's. As mentioned in an earlier section on black nationalistic theologies, a speaker at the UNIA's first meeting was none other than Dr. Alonzo Burgess Holly, the son of the black Christian nationalist James Theodore Holly, who, in the later years of the nineteenth century, left the United States for Haiti. Dr. Holly had been involved in black nationalist causes prior to moving to Colored Town to practice medicine. He addressed the audience on "the revolutionary activities of his native country of Haiti.", 78 
Another radical leader, the charismatic Laura Adorkor Koffey, who referred to herself as the "Warrior Mother of Africa's Warriors of the Most High God.",79 set up a branch of her church, the African Universal Church, in Miami in the 1920's. Her other branches were located in Jacksonville, St. Petersburg, Tampa, Mobile, Belforest-Daphne City, Alabama, Atlanta, and New York City. Originally she was a member of Garvey's UNIA, often delivering speeches to try to persuade blacks that "they need freedom and Africa needs them." But in early 1928 Koffey began to break from the UNIA, criticizing some of its practices. She opposed its dances and other fund raisers and suggested replacing them with prayer groups. She was also critical of the UNIA's uniformed African Black Legion for drilling on Sundays. Koffey was a charismatic preacher and churchgoers began leaving their own churches to hear her preach on Sunday mornings. She evidently encouraged her new followers to break with the UNIA and to join her African Universal Church. Eventually she angered Garvey himself, and many in Miami's black community, including the leadership of the UNIA (including James Nimmo, the head of the African Black Legion). She also angered the local clergy, who did not want to lose members but also found her views too radical; they wanted to maintain good relationships with the local white community. ${ }^{80}$

Koffey was murdered on March 8, 1928 while speaking in Miami's UNIA hall to solicit funds for a back to Africa exodus, a fund raising effort for which Garvey did not authorize. Her murder terminated Miami's UNIA chapter (although Koffey's church continued to operate). One of its more radical members, James Nimmo, would emerge as an active participant in Miami's mid-century socialist and labor movements and continue 
his involvement in the Civil Rights movement, forming coalitions with Jewish activists who had moved to Miami from northern cities. ${ }^{81}$

\section{Black Associational Ties}

Associational ties between black groups that extended outside of Perrine itself, in neighboring South Dade areas, increased the power of blacks, therefore increasing their holding of civic social capital. There were a number of activities through which blacks in the villages of southern Dade County, from Coconut Grove through Homestead, established ties to one another. This section will attempt to identify some of the key black associations in which Perrine's residents participated. These activities developed and strengthened networks between blacks, developed cohesion, and strengthened identity

The first intra-community effort among blacks to organize was in the area of education. In this endeavor, the efforts of Arthur and Polly Mays, who, as already mentioned, contributed to the establishment of the first public school for black children in Goulds in 1914, were unsurpassed and had long-lasting beneficial ramifications for the black community in southern Dade County. Arthur Mays, who had only six weeks of schooling himself, was born in Floville, Georgia in 1887. He moved to South Dade and worked briefly for the Peters family as a house boy before buying a farm in Naranja, south of Perrine. In 1926, he was instrumental in persuading the School Board to establish Goulds Elementary School and donated land to the School Board for the school. He approached the School Board for money to help for the transportation for black 
children in South Dade to go to high school, as there was up to a twenty five mile distance to the nearest school in Coconut Grove but they offered so little that he refused it. He and his wife raised money for three buses and personally transported children throughout South Dade, stopping at all the villages from Homestead to Coconut Grove twice a day. They paid for the gas, collected books and grew produce for lunches. They continued to press the School Board for more schools, and in 1935, were finally successful in persuading the School Board to open a high school for blacks in Goulds, for which they continued to provide the transportation. ${ }^{82}$

Many associational ties were created through church activities. Doc Coleman and Robert Bruce Ingraham, for example, eventually established numerous Holiness Churches throughout southern Dade County. ${ }^{83}$ It was also common for churches to develop ties with one another by fellow-shipping with one another-inviting other churches to worship with them on regular Sundays or at revivals or sing-ins. These activities developed and strengthened networks among blacks, developed cohesion, and strengthened identity. As was already mentioned, Perrine's Masons, also included members from Goulds.

Other associational ties included Negro baseball teams, formed by farm-workers throughout southern Dade County, which played each other in the various villages, membership in civic associations and on boards. The first hospital and clinic for blacks in southern Dade County, Lincoln Memorial in Goulds, was spearheaded in 1948 by Arthur and Polly Mays. Until it was built, the closest hospital that would accept blacks was twelve miles north of the Perrine/Goulds area. Charter members included Perrine 
civic leaders Doc Coleman and Ben Shavis. Later Neil and Louis Shackeford and Don L. Williams became board members. ${ }^{84}$

During the 1940's Perrine's civic leaders including Doc Coleman, Ben Shavis, and Rev. Ingraham belonged to the South Dade chapter (there were three in Dade County) of the NAACP. Don L. Williams, the former foreman and migrator for Robert Kerr was its first president. ${ }^{85}$

\section{Perrine Incorporates}

By then end of WWII changes were occurring in Miami and throughout the county due to population increases, an expanding county power base, and increased development which was encroaching on farms in South Dade. These factors fueled the desire of Perrine's white growers to reorganize themselves politically to maintain control over their economic interests. The population of Dade County had grown by 87.3 per cent during the 1930 's and 84.9 per cent during the 1940 's. ${ }^{86}$ More and more people were moving into Dade County, especially after the war, which created an overwhelming demand for housing. In South Dade many farmers were finding it profitable to sell their land to developers. Some smaller farmers had already begun to sell and the larger growers were also feeling the market's pressure.

The increase in population also created a demand for municipal services that the county government was finding it difficult to provide. As a result, the existing county government, which included the rapidly expanding unincorporated area of Dade County, began to provide more services, and its status and power base began to strengthen. ${ }^{87}$ 
Most of the municipal services, however, if provided at all, were still administered by the twenty six separate cities in the metropolitan area. By 1948 efforts were afloat to try to consolidate these disparate services into one central metropolitan county government. The white growers, who had seen Perrine's population increase from 2000 in 1945 to 3500 by 1948 , opposed this movement and decided that they could best protect their interests if they would incorporate as a municipality. ${ }^{88}$

There were more blacks living in Perrine than whites, and Perrine's white growers, led by Robert Barfield, knew that they needed to enlist black participation in forming their new government. This would not be the first time whites in Miami would seek black votes to incorporate, nor the first time black participation in government would be quickly ended by stronger societal forces. In 1896, 162 of the 368 votes cast in favor of Miami's incorporation were from black voters. (More than 250 registered voters were needed for Miami to incorporate as a city) ${ }^{89}$ Shortly after that vote, blacks were disenfranchised by a series of state statutes in 1897 and 1901 that allowed the Democratic Party to exclude blacks from membership, and then imposed a poll tax, further reducing the number of black voters. Despite the repeal of these acts, (poll tax in 1937 and white only primary in 1944), racial intimidation and violence continued to prevent meaningful black participation in local government. ${ }^{90}$

The first large-scale organized effort to register blacks to vote in Miami was led by black-oriented newspaper owner Sam Solomon in May of 1939. On the eve of the election the Ku Klux Klan staged a large rally, attended by more than 2,000 people, followed by an automobile parade with seventy-five cars. Hooded Klansmen burned crosses, carried a dummy of a black man with a noose around his neck, and threw 
warning cards from their cars that said, "Respectable negro citizens are not voting tomorrow. Niggers keep away from the polls." Not intimidated, Solomon and civil rights activist Reverend John E. Culmer announced that black voters intended to go to the polls in record numbers. In an ironic twist, they secured police protection headed by none other than police chief H. Leslie Quigg, who in the 1920's had been suspected of having Klan ties and had denied not denied these allegations. Indeed, 1,500 black voters voted, the largest black turnout to date in Miami's voting history. ${ }^{91}$

The following fall, amendments to change the form of government were put before the public, proposing to introduce the ward system of government in place of the election of commissioners at large. This entailed a lengthy public debate with concerns that one to four black commissioners might be elected under this new system. ${ }^{92}$

In light of this long history of black disenfranchisement, would Miami be ready for a bi-racial government in the year 1948? Robert Barfield, long time Perrine grower and business man, former county commissioner, and well respected among both blacks and whites, ${ }^{93}$ approached Perrine's Negro Counsel members to try to garner support for incorporation. He was met with skepticism from blacks, however, many of whom did not wish to become involved in "white people's business" because the current racial environment was not one that would be likely to allow black people to participate even partially in an integrated government. Black involvement was likely to engender a confrontation with a hostile outside society, the benefits of which did not appear to outweigh the risks. Yet in spite of the black community's distrust of the wider white society, there were long-standing bonds of trust that had been cultivated over nearly a 
half century between local blacks and whites. It was this trust that Robert Barfield appealed to when he approached church and community leader, Robert Bruce Ingraham.

Robert Bruce Ingraham and Robert P.Barfield had known each other since the early years of Perrine's history. Besides farming (Barfield owned some of the largest acreage in the Perrine area), Barfield had owned Perrine's General Store since 1910, and then Barfield's Department Store (the largest business in Perrine) since $1935 .^{94}$ Like Barfield, Rev. Ingraham was also well known and respected by whites and blacks alike. His daughter-in-law described him "like a wise person" and his son, as "something like a handyman. Everybody, everybody, white and black people came to him. Some time at night there would be a line of people. Everybody want him. Somebody want to talk to him about how to get along with their wife. Somebody how to buy a car. Somebody else want to know how to build a house. Somebody else want to know how to buy some land. And there would be a line of people to talk to my dad. And he would be there. My mother didn't like it because he was so involved with these people. But he was not out there to be involved in political business. He was not that. He was only but he had the wisdom so that everybody would come looking for Robert Bruce Ingraham. Let's go find Rev. Ingraham. Let's go find Rev. Ingraham." 95

Remembering Barfield's attempts to persuade his father to convince Perrine's black community to vote for Perrine's incorporation, Bishop Joseph Ingraham relates, "So then it was Mr. Barfield who would come over so many times I could remember. I was a teenager and he would try to get, 'Brucie, Brucie, please. You fellows are the ones here. You are the citizens here. You must become involved. We want to make a town. We want to incorporate. And you must become involved.' And it was a while before he 
got my dad interested. And once he got my dad interested, then my dad began to tell others, 'Let's go. Why don't you go?' And so then they started opening and going over and becoming open." 96

Initially reluctant, eventually Perrine's black community backed Barfield's plan. On March 15, 1948 Perrine's citizens voted to incorporate. Barfield was sworn in as mayor the next day and elections for a new set of elected officials was set for the following November. Church leaders, including Rev. Doc Coleman, a prominent Republican, registered enough black voters (there were 316 black voters to 278 white voters) to insure that the black president of the Negro Counsel, Ben Shavis, would be elected as commissioner, and then would have enough votes to become the first black mayor of Perrine. ${ }^{97}$

On the eve of the November election, the Ku Klux Klan announced that they would be riding through Perrine in an effort to convince Shavis, Coleman, and anyone else in town thinking of taking part in a bi-racial government to think differently about their plans. Bishop Ingraham was at home alone and in charge of watching his younger siblings. He gave an account of the evening's events: Ingraham watched as a state trooper pleaded with his next door neighbor, Doc Coleman, to leave with his children, saying that the police could not offer him protection from the Klan "And they said, you had better leave here because they are getting ready up there, and they are coming after you." According to Ingraham, state troopers came to Doc Coleman's house three times that night, pleading with Coleman to leave town, explaining that "the government has not given us sufficient help to protect you all." Coleman sent his children to stay with family or friends outside of Perrine but refused himself to leave. He told Ingraham, "I remember 
seeing white people kill my daddy in Georgia. I'm looking at 'em. [He said] I'm not going one step. I'll be right in that house there." Ingraham himself was terrified. First he decided to go to the "Jew Store" with his last dollar and buy two boxes of bullets for his twenty-two caliber rifle. ${ }^{98}$ Then he waited out the night on his porch, looking to his older neighbor for courage: "Every time I went outside and go over to the house and hollered for him he hollered back at me. So I just sat there on the porch. Said, well, whenever they come, that's it. And every time we're looking and see an automobile light. .. . I would see "em." Over on Homestead Avenue, the Masons barricaded the street and waited out the night armed with shotguns. There were reports of crosses burning on lawns but no violence erupted that night. ${ }^{99}$

Ben Shavis got the message and he left town for a few days. (Some say he went to upstate Florida, others say the Republican Party offered him safe haven locally.) When he returned he dropped out of the race, but he denied that it was because his life was threatened. According to the Perrine clerk who took his withdrawal notice, Shavis told her, "I talked it over with the Lord, and the Lord told me to withdraw." Coleman filed a complaint with the Republican Club, alleging that "Shavis, a registered Republican, had dropped out of the race under threat of death and left town for safety's sake."100

Barfield was voted mayor of Perrine instead of Shavis. The failed attempt to put together a legally sanctioned integrated government based on inter-racial cooperation fomented a bitterness in the hearts of blacks and whites who had worked together. When Shavis withdrew from the race, so did four white candidates. At least two of them, Mac Hagan and Peters, were growers with long-standing positive relationships with blacks. ${ }^{101}$ 
Two months later, Barfield, along with three other commissioners, offered their resignations. Barfield was quoted in the Miami Daily News, Feb. 22, 1949, as saying, "I want to get out of the city of Perrine and I want to get my property out." Indeed, by May, the town had been abolished. The next decade would find most farms in Perrine being sold.

This example illustrates that Perrine's black community possessed enough civic social capital to entice the white growers to try to work with them. It is unlikely, given the existing social climate of that period, that the white growers would have been motivated by social considerations; i.e., a desire to improve the social and political conditions of the blacks, or to form a bi-racial government. The whites obviously believed that the blacks had an amount of political and social power necessary to assist them in achieving their own political goals. Their apparent willingness to share power with blacks was also a result of solid relationships that whites had formed with many of the black citizens of Perrine. That the black community had developed strong relationships even with the state police was demonstrated by the expressed regret of the police at not being able to protect the Perrine community. ${ }^{102}$ Blacks were equally ready to cooperate with whites and did so, despite Shavis' abandonment of the election, when they voted in sufficient numbers to approve incorporation of Perrine (an important investment of their civic social capital, albeit an ill-fated one). The coalition between Perrine's whites and blacks, who had collaborated in the effort to form a legally sanctioned bi-racial governing body, was a challenge to the white system that for years had exercised its dominance over blacks. As will be seen, the failure of this joint effort had negative implications for both of these parties. 


\section{The "Incorporation Story" as an Instrument of Civic Social Capital Accumulation}

Stories or histories that communities retell and pass down to subsequent generations are important because they contain truths, values, and other cultural information by which communities shape their identities and their aspirations. In turn, this is what facilitates collective action. Although the central application of black Perrine's civic social capital ended in a failure, this event, in which Perrine's religious leaders played such an important role, became one of the most important stories Perrine told about itself. Over time, the Perrine community developed "The Incorporation Story," to embody the truths and values it most cherished. In 1978 the Perrine community would dedicate a small park to Ben Shavis, whom it would designate as the hero of its incorporation story. Inscribed on the memorial plaque is the following:

Benjamin Samuel Shavis, 1890-1968: Ben Shavis was a man who made life a little nicer for the black community of West Perrine. He staged clean-up campaigns, worked with the community youth, encouraged people to purchase their homes, and served as Sunday school superintendent. Officially he was chairman of the Perrine Negro Council and rallied neighbors to register and vote. In November of 1948, when Perrine was an incorporated city, Shavis was the only black among the fifteen candidates running for seven commissioner seats. His election seemed secure until racial tensions forced his withdrawal from the race. In 1978 the community of West Perrine dedicated this park in honor of Ben Shavis.

There were actually several versions of "The Incorporation Story" In one version

Perrine actually had a black mayor: Shavis was elected mayor before he was run out of town by the Klan. In a second version the Klan burned crosses on lawns throughout Perrine. In yet another version Shavis was a Democrat. ${ }^{103}$ Other versions included three black men, Shavis, Doc Coleman and Louis Shackelford, as running for the Commission. 
The significance of these many versions of the incorporation story lies less with the historical accuracy of its details, than with the values the community wishes to impart and the legacy it wishes to pass to succeeding generations. It is a story told with pride about a generation of pioneers who built Perrine, their churches, their houses, and their roads with their bare hands. It speaks of the value of communal cooperation in achieving civic goals. There is a tremendous pride in the fact that Perrine had a Negro Council and that through its efforts, two black police officers were hired, ${ }^{104}$ streetlights were installed, and the garbage was removed. There is pride in the fact that Perrine was incorporated, if only for a brief interval, and that blacks from Perrine were participants in the political process.

The incorporation event, situated as it was in the context of other important challenges to Miami's exclusionary political system by black activists elsewhere in Miami, placed Perrine well ahead of the national civil rights movement. ${ }^{105}$ Historian Marvin Dunn, in fact, commenting on the numerous accounts of black activists in Miami in the years preceding the national movement, concluded that "the civil rights period in Dade County predated the civil rights period in other parts of the South by at least a decade." 106 Ben Shavis, Doc Coleman, Robert Bruce Ingraham and the others who fought for black inclusion in government just as the Civil Rights Era was beginning are Perrine's heroes. Their struggle is foundational to Perrine's civic engagement to this day. 


\section{NOTES}

${ }^{1}$ Social scientist Daniel Elazar proposed looking at cultural streams, a charting of the movement of cultures via human migration, as a way to understand the social understructure of a region under study. He wrote, "Just as every human settlement has a natural geographic and geologic base which has formed over the centuries to create the region's physical environment, it has a social base which has become so rooted that it can be described as being as "natural" as any rock formation, soil composition, or drainage system." (Daniel J. Elazar, Building Cities in America: Urbanization and

Suburbanization in a Frontier Society [Lanham, MD: Hamilton Press, 1987], xv-xvi)

${ }^{2}$ Report to accompany bill S. No. $241,25^{\text {th }}$ Congress, $2^{\text {nd }}$ Session, March 12 , 1838, p.2.

${ }^{3}$ William E. Brown, Jr. And Karen Hudson, "Henry Flagler and the Model Land Company," Tequesta, LVI (1996), 47.

${ }^{4}$ Paul George discusses efforts in Miami in the early decades of the twentieth century to limit blacks residentially to a section reserved for blacks only, called Colored Town. He cites instances in 1911, 1915, and 1920 when, according to the white press, white violence erupted "to force the negroes back across the "color line."" (George, "Colored Town," 320).

${ }^{5}$ Model Land Company Records, Archives and Special Collections, University of Miami, Coral Gables, Florida.), Box 7, Folder 208, File 240.

${ }^{6}$ Jean Taylor, The Villages of South Dade (St. Petersburg, Florida: Byron Kennedy, 1986), 55.

${ }^{7}$ The terms of the grant, for which Dr. Henry Perrine spent years petitioning Congress, stipulated that a settler be placed on each section to introduce and cultivate tropical and semi-tropical plants of commercial value by 1846 . Perrine was killed by Indians in 1940, before the terms of the grant could be fulfilled. Despite the unsuccessful efforts by his partner, Charles Howe, to comply with the terms of the grant (he brought thirty six Bahamian families to settle the land but they were driven away because of conflicts with the Seminoles), Congress passed the grant to Perrine's heirs. (Villages, 1-4; Brown and Hudson, "Henry Flagler and the Model Land Co; Report to accompany bill S. No. 241).

${ }^{8}$ Taylor, Villages, 8-10.

${ }^{9}$ As indicated by records of disputes between the MLC and squatters (Model Land Co. Records) and by interviews (Bishop Joseph Ingraham, Bishop of Community Church of Christ Written in Heaven, Perrine, and Mrs. Ingraham, his wife. Interview by author, tape recording, 30 January 2003, Perrine, Florida); MLC records show that squatters 
lived on land managed by this institution as late as 1939. (Letter written by MLC surveryor, John W. Sommerville to Mr. M. C. Jessee of Pepper and Coffrin, March 23, 1950, Model Land Company Records, File no. 232).

${ }^{10}$ There is documentation dating from before 1790 indicating Bahamian (blacks and whites) settlements in the Florida Keys, established there as part of their wrecking enterprise. In addition to wrecking, many of these settlers fished, sponged, turtled, farmed and cut wood in the Keys. By the time the U.S. acquired Florida in 1821, some fifty to sixty vessels, and more than 500 New Providence seamen were regularly employed in the wrecking industry.. (Dorothy Dodd, "The Wrecking Business on the Florida Reef:18221860, "Florida Historical Quarterly XXII, no. 4 (April 1944), 174-175); Other Bahamian roots in South Florida include the Black Seminoles, a group of escaped slaves who had associated with Seminole bands in Northern Florida and then were pushed into the southern part of the Peninsula by the U.S. Army during the First Seminole War. There they were smuggled into the Bahamas by wreckers and settled on Andros Island. (John M. Goggin, "The Seminole Negroes of Andros Island, Bahamas," Florida Historical Quarterly XXIV, no. 3 (Jan. 1946), 200-206; Kenneth W. Porter, "Notes on Seminole Negroes in the Bahamas," Florida Historical Quarterly XXIV (July 1945), pp 56-60; Rosalyn Howard, Black Seminoles in the Bahamas, [Gainsville, Florida: University Press of Florida, 2002], 32-33); Still other Bahamians had been slaves in East Florida and followed the British Loyalists to the Bahamas during the American Revolution. (Thelma Peters, "The Loyalist Migration from East Florida to the Bahama Islands," Florida Historical Quarterly XXXX (Oct. 1961), 123-141.) A new wave of black Bahamians began to arrive in South Florida beginning at the end of the nineteenth century, attracted by the economic opportunities - building and railroad construction generated by the growth of the new city of Miami and encouraged by Henry Flagler.

${ }^{11}$ Raymond A. Mohl, "Black Immigrants: Bahamians in Early Twentieth-Century Miami," Florida Historical Quarterly LXV, no. 3 (Jan. 1987), 272 quoting Larry Smith, "Coconut Grove: Bahamian Roots in Florida," Nassau Tribune, October 12, 1977, clipping file, Miami-Dade Public Library, Miami, Florida.

${ }^{12}$ In the present day Colonial Drive area.

${ }^{13}$ There were two types of land in South Dade, glades land (also called muck land or marl prairie), and rock land (also called pine land). Jean Taylor offers a description of these lands and their changing economic value in "Scarifying South Dade," (Update, Vol. 5, no. 1 [October 1977], 4-5):

Before the turn of the century when South Dade land was made available for homesteading, the quarter sections, which were mainly glade land, were not opened, as it was supposedly waste land not suitable for homes. The early spring rains would catch the farmer before he could finish harvesting and hurricanes would flood him out in the fall. All of the high, dry pine land from Miami south 
was rocky and became more rocky the farther south it went. Some land seemed to have less than a bushel of soil to the acre, and what there was was composed of a sterile sand that wouldn't grow anything. The redland area was the exception, with soil of a red clay and sand mixture. The early pioneers planted their seeds in pockets of soil available here and there and ignored the rocky pine lands. Then one of those discoveries was made which revolutionized the use of the South Dade farmlands-scarifying.

The MLC divided their holdings into these two varieties, selling the valuable glades land to growers who would need to "improve" them by draining before they could grow vegetables. The less valuable rocky pine land was designated by the MLC as suitable for citrus farming. Because of the larger capital investment needed to drain the glades land, large tracts were sold to white growers or corporations who had more capital to invest or more credit.

${ }^{14}$ Bishop Ingraham interview, Jan. 2003.

${ }^{15}$ Fannie Mae Williams. Fannie Mae and Sinclair Williams of St. Peter's Missionary Baptist Church, Perrine, interview by author, 14 March 2002, Perrine Florida.

${ }^{16}$ Although the Model Land Company sold permits to lumber companies and private.individuals to cut wood on their holdings, for the most part the Bahamians did not buy these permits. (Bishop Ingraham interview, Jan. 2003); Model Land Company records show instances of their agents apprehending "colored men" who were cutting wood off their land without a permit. 2002.

${ }^{17}$ Bishop Ingraham interview, Jan. 2003; Fannie Mae Williams interview, March

${ }^{18}$ The first large grower (his two hundred acres abutted the village of Perrine) in Perrine, and, according to Jean Taylor, the first successful planter in the "glades" was Tom Peters, who in 1901 had built up his business to the point of employing hundreds of pickers and packers, black Bahamians he brought in to work the tomato season. $\mathrm{He}$ housed his workers in the barrel staves made from manure barrels he brought in from Key West to fertilize his tomato plants. Before good fortune brought the FEC extension through his property, much of which he obtained before the MLC acquired its Perrine Grant holdings, he built a tram line with wooden rails from his packing house to his dock in Cutler, a small port along Biscayne Bay four miles away, with mules pulling his tomatoes in railroad carts. In 1903 the MLC built a siding and station just west of his packing house. (Taylor, Villages, 13-14).

${ }^{19}$ This church was originally named Pine Grovers. A year after its formation it affiliated as an AME church after Bishop Hurst of the Southern District AME (African Methodist Episcopal) in Jacksonville, Florida sent a pastor to conduct a revival meeting 
in Perrine in 1913. (Villages, 56); A Hurst Chapel Sunday church program describes the formation of this church: "a newly arrived group of Bahamians, accustomed to worshiping God on the Sabbath, realized that, next to finding lodging for their families, they must have a place of worship." It was renamed Hurst Chapel AME in 1926, when a hurricane destroyed the church and Bishop John Hurst sent money to help rebuild it. (Jean Taylor research papers, Historical Museum of Southern Florida, 1011 West Flagler St., Miami, Florida 33130).

${ }^{20}$ According to Bishop Joseph Ingraham, his father inherited this property as a result of prior squatting and the settlement was negotiated by the Squatter's Union.(Bishop and Mrs. Ingraham interview, January 2003).

${ }^{21} \mathrm{He}$ formed his Holiness church after a conversion experience led him to establish a church based on living a righteous life "every day and not just on Sunday," and on the "real salvation, the Holy Ghost, the Spirit of God," rather than the "regular salvation" practiced, according to Ingraham, by most other churches.

${ }^{22}$ These churches were Mt. Sinai Baptist Church, and the Methodist church that would eventually be named Kerr Memorial.

${ }^{23}$ Doc Coleman had founded The First Born Church in Titusville in 1927 before arriving in Perrine, the only black man at the time to have a car. His church in Perrine eventually grew to seven throughout the region. He would become the first black licensed electrician in Dade County. (Fannie Mae and Sinclair Williams interview, March 2002; Mr. Archie Finkley, member of Mt. Sinai Baptist Church, Perrine. Interviews by author, 15 February, 2002, and 20 February, 2002, Perrine, Fla.)

${ }^{24} \mathrm{Mrs}$. Ingraham interview, April 2002.

${ }^{25}$ These workers had connections to other blacks living in Northern Florida and Georgia and were in charge of hiring seasonal laborers for their bosses.

${ }^{26}$ Bishop and Mrs. Ingraham interview, January, 2003.

27 "Miami Chapter/American Institute of Architects- West Perrine Charrette: AIA Florida/Design Assitance Team," November 13 and 14, 1992, page 5.

${ }^{28}$ Vester Jefferson, member of Mt. Sinai Baptist Church. Interview by author, 25 March 2002, Perrine, Florida.

${ }^{29}$ Fannie Mae Williams interview, March 2002.

${ }^{30}$ Bishop and Mrs. Ingraham interview, April 2002; Fannie Mae Williams interview, March 2002; Delores Alexander, pastor of Faith Triumph Church of God in Christ in Goulds, Fla. Interview by author, 11 April 2002, Perrine, Fla. 
${ }^{31}$ Fannie Mae Williams interview, March 2002.

${ }^{32}$ Whittington B. Johnson, Race Relations in the Bahamas, 1784-1834: The Nonviolent Transformation from a Slave to a Free Society (Fayetteville: The University of Arkansas Press, 2000), 35-37.

${ }^{33}$ Historian Paul S. George noted marked attitudinal differences between Bahamian and American Blacks. Writing about police and black interactions in the early 1920 's he says, "Bahamian blacks who settled in Colored Town and in Coconut Grove were a volatile element. Many came at harvest time and worked in the South Dade agricultural groves. As temporary residents and British subjects, they were less servile toward whites than native blacks. Because numerous Bahamians preached racial equality, many whites regarded them as trouble." (George,"Policing Miami's Black Community, 444); Raymond Mohl, although not distinguishing between Bahamian and American black attitudes, noted that Miami's blacks confronted Jim Crow often aggressively and were not intimidated by threats by the Ku Klux Klan as were blacks in other cities. (Raymond A. Mohl, "Making the Second Ghetto in Metropolitan Miami, 1940-1960." Journal of Urban History, (March 1995),408-410). It may be presumed that the Bahamian black influence was strongly felt as by 1920 they made up of fifty-one per cent of Miami's black population. (Raymond A. Mohl, "Shadows in the Sunshine: Race and Ethnicity in Miami," Tequesta, XLIX (1989), 67).

${ }^{34}$ Bishop and Mrs. Ingraham interview, April 2002.

${ }^{35}$ Johnson, Race Relations, 35-66.

${ }^{36}$ Two politically influential Espiscopal Churches (Saint Agnes Episcopal church, established in 1897 in Colored Town and Christ Episcopal Church, established in 1901 in Coconut Grove) formed during the early history of Miami by Bahamians who were part of the Anglican Communion in the Bahamas. The churches were named for churches in the Bahamas to which their members had belonged, and were built in a similar fashion: i.e. Christ Church was painted the traditional Bahamian pink color. Originally these two churches were ministered by the clergy of Trinity Church, a white Episcopal church in Miami, but eventually these two churches became independent of Trinity. St. Agnes was founded by a white clergyman. (Marvin Dunn, Black Miami in the Twentieth Century, [Gainsville: University Press of Florida 1997], 109-111).

${ }^{37}$ Bishop Ingraham interview, January 2003.

${ }^{38}$ Ibid

${ }^{39}$ Green is speaking about the increase in Pentecostalism across the denominations. Indeed scholars have identified a Neo-Pentecostal, or charismatic movement emerging in nearly all the Protestant denominations, the Roman Catholic 
Church, and in the Eastern Orthodox communities during the 1960s. At the time of this writing, many Pentecostal elements, as evidenced by worship styles, music, laying on of hands, and other ecstatic practices, had become part of Perrine's mainline churches, as well.

${ }^{40}$ Green interviews, October 2001, April, 2002.

${ }^{41}$ The Holiness movement grew out of John Wesley's (1703-1791) call to perfectionism (his doctrine of sanctification held that believers could be entirely sanctified in a second work of grace and by faith alone by which the Holy Spirit would cleanse their hearts from their bent to sinning and restore in them God's image of love). The doctrine of sanctification entered the American religious environment by way of Methodism during the Great Awakening and continued to influence American Protestantism by way of subsequent revivals. By 1866, when a new wave of weekday holiness meetings and revivals began to sweep America (as well as other countries), perfectionism had come to mean the regeneration both of the individual and of society. The immediate origins of the Pentecostal movement developed within the radical, separatist wing of the late nineteenth-century Holiness movement in the United States. It adopted Holiness views on premillennialism, dispensationalism, faith healing, and "the Baptism in the Spirit" leading to miraculous powers. When the Pentecostal movement began (by Holiness preacher Charles Fox Parham in 1901 in Topeka, Kansas) speaking in tongues and other ecstastic behaviors were introduced. Black Holiness preacher William Joseph Seymour stimulated a great Pentecostal revival in 1906 when he carried the movement to the Azusa Street Apostolic Faith Mission in Los Angeles. Visitors to the Azusa mission spread the movement across the nation and around the world in only a few years. (Although begun as an inter-racial movement, by the 1930's the Pentecostal movement had split along racial lines). [Robert Mapes Anderson, Vision of the Disinherited: The Making of American Pentecostalism, (New York: Oxford University Press, 1979)]; Perrine's community members do not tend to distinguish between Pentecostal and Holiness churches and use these terms interchangeably. Since the movement began, in fact, so many doctrinal and other variations have developed it serves no useful purpose to try to separate them. I will refer to this phenomenon as the Holiness/Pentecostal or the Sanctified tradition.

\section{${ }^{42}$ Vision of the Disinherited, 32.}

${ }^{43}$ They retained ties to Chipley, Florida where they eventually moved. (James Shackelford, son of Neil Shackelford of Hurst Chapel AME, Perrine. Interview by author, 18 March, 2002, Perrine, Florida; Finkley interview, February, 2002; Fannie Mae and Sinclair Williams interview, March 2002; Bishop and Mrs. Ingraham interviews, April 2002 and January 2003.)

${ }^{44}$ As will be discussed below, the Masons served as a type of police protection, especially to counter the threats of the Ku Klux Klan. 
${ }^{45}$ Bishop and Mrs. Ingraham interviews, January 2003.

${ }^{46}$ Brown and Hudson, "Henry Flagler," 55.

${ }^{47}$ Model Land Company Records, Box 1, Folder 8, File 9, Letter from Mr. J. E. Ingraham to Frederick S. Morse, March 2, 1911; Model Land Company Records, Box 7, Folder 215, File 247, Letter from Mr. J. E. Ingraham to Frederick S. Morse, Dec. 12, 1914.

${ }^{48}$ Model Land Company Records, Box 6, Folder 200, File 232, Letter from Frederick S. Morse to James E. Ingraham, October 8, 1914; Letter from James E. Ingraham to Frederick S. Morse, November 2, 1914.

${ }^{49}$ Model Land Company Records, Box 28, Folder 668, File 8121, Letter from Frederick S. Morse to Sidney Harrison, April 18, 1919.

${ }^{50}$ Redlining, which will be treated in a later section, was an elaborate appraisal and rating system adopted by banks and other lending institutions which refused to grant mortgages to those wishing to buy in older, poorer, and minority neighborhoods. Developed and undeveloped lands were subject to redlining. (Mohl, "Whitening").

${ }^{51}$ Model Land Company Records, Box 93, Folder 1673, File 2109, Letter from Pepper and Coffrin to Mr. Carl W. Hawkins, Vice-Pres. of Perrine Grant Land Company, Feb. 9, 1943.

${ }^{52}$ Brown and Hudson, "Henry Flagler," 69;Mohl, "Making the Second Ghetto," 396,405 .

${ }^{53}$ Chidester, Patterns of Power, 7.

${ }^{54}$ Doug Andrews, "Black Education in Miami, 1921-1940," Tequesta LIV (1999), 30-51; Asterie Baker Provenzo and Eugene F. Provenzo, Education on the Forgotten Frontier; A Centennial History of the Founding of the Dade County Public Schools, (Miami: Dade County Public Schools, 1985), 29-43; Thelma Peters, "Miami's First School," Update, Vol. 1, no. 3, (Feb. 974), 6-7; Villages, 7.

${ }^{55}$ Villages, $56-57$.

${ }^{56}$ This church, Mt. Pleasant Missionary Baptist Church was sometimes referred to as the "high-yellow church," because of the lighter skin color of some of its prominent early members. (Dunn, Black Miami, 114-115).

${ }^{57}$ Ibid, 56-57, 90. 
${ }^{58}$ Ibid, 56-67.

${ }^{59}$ Raymond A. Mohl, "Miami's Metropolitan Government: Retrospect and Prospect," Florida Historical Quarterly LXV, no. 1 (July 1989), 29.

${ }^{60}$ Scarifying is the clearing of the land in preparation for planting or paving. First the land is cleared of trees, grass and shrubs, and then the land is plowed in four different directions, pulverizing the ground. Special tractors and plows were developed for this purpose since the land was very rocky. Taylor, "Scarifying South Dade," 4.

${ }^{61}$ Fannie Mae and Sinclair Williams interview, March 2002; Archie Finkley interviews, Feb. 2002; Bishop Ingraham interviews April 2002 and January 2003; James Shackelford interview, March 2002.

${ }^{62}$ Raymond A. Mohl, "Whitening Miami: Race, Housing, and Government Policy in Twentieth-Century Dade County," Florida Historica Quarterly, Vo. 79, no. 3 (2001)

${ }^{63}$ Model Land Company Records, Box 96, Folder 1715, File 2166: Letter from J. Lamar Paxson to Pepper \& Coffrin, Inc., Jan. 5, 1937; Letter from Pepper and Coffrin, Inc. to Mr. J. W. Hoffman, Vice-President of the MLC, Jan. 6, 1937; Letter from Pepper and Coffrin, Inc. to Mr. Carl W. Hawkins, Vice-President of the Perrine Grant Land Company, July 15, 1940; Letter from Paul W. V., Vice-President of the MLC, July 17, 1940; Letter from Pepper and Coffrin, Inc. to Mr. J. Lamar Paxson, July 19, 1940; Memorandum by Milo Coffrin, Oct. 9, 1940. Letter to Mr. Carl Hawkins, Jan. 7, 1941.

${ }^{64} \mathrm{By} 1940$, letterheads indicate that Paxson had become the chairman of the Board of County Commissioners. There are indications in the letter cited above, dated Oct. 9, 1940 , to suggest that eventually, Paxson may have gained the influence necessary to broker the deal for roads in the Negro with the commissioners as part of their normal agenda.

${ }^{65}$ Bishop Ingraham interview, April 1 2002; Fannie Mae Williams interview, March 132002.

${ }^{66}$ Raymond A. Mohl, South of the South: Jewish Activists and the Civil Rights Movement in Miami, 1945-1960 (University Press of Florida: Gainesville, 2004), 22-23.

${ }^{67}$ Bishop and Mrs. Ingraham interview, January, 2003; Archie Finkley interview (with Delores Alexander), Feb., 2002; James Shackelford interview, (with Delores Alexander and Archie Finkley), March 2002.

${ }^{68}$ James Shackelford interview, March 2002.

${ }^{69}$ Archie Finkley interview, Feb. 2002. 
${ }^{70}$ Suzy Harvey headed Perrine's Eastern Star division. She was also the unofficial community historian, eulogizing the deceased. (Archie Finkley interviews, Feb. 2002; Shirley Green [pseud.], pastoral counselor of Faith in Christ Holiness Church [pseud.], Perrine. Interviews by author, March 2001, October 2001, April 2002, Perrine Florida.)

${ }^{71}$ This large Bible which sits on Mr. Finkley's living room table, is evidently the one he uses. (Archie Finkley in Vester Jefferson interview, March 2002.)

${ }^{72} \mathrm{~A}$ list of presidents of the United States who were Freemasons was included in the edition cited above. Vester Jefferson interview, March 2002.

${ }^{73}$ James Shackelford interview, March 2002.

${ }^{74}$ The Bible speaks of Cities of Refuge (Ex. 21:13, Dt. 4:41, Nu. 35:11 and Dt.19:4) as cities where murderers who killed unintentionally and without hatred or malice could find protection from the retribution of family members.

${ }^{75}$ Bishop and Mrs. Ingraham interview, January 2003.

${ }^{76}$ Delores Alexander in Shackelford interview, March 2002.

${ }^{77}$ Vought, "Racial Stirrings."

78 "Reports by Bureau Agent Leon E. Howe, Miami, Florida, 7/16/21," Garvey Papers, Volume VI, 514, quoted in Vought, "Racial Stirrings; Although Dr. Holly had strong nationalistic sentiments and was supportive of the UNIA, it is not known whether he became a member of this organization.

79. Hans A. Baer, and Merrill Singer, African American Religion: Varieties of Protest and Accommodation, (Knoxville: The University of Tennessee Press, 2002), 131.

${ }^{80}$ Vought, "Racial Stirrings."

${ }^{81}$ Koffey's killer was never discovered, or according to some, found guilty. The police arrested Nimmo and UNIA president, Claude Green along with other UNIA members. Most were released the following day but Nimmo and Green were indicted in the murder of Koffey, tried, and acquitted. (Voight, "Racial Stirrings;" Mohl, South of the South).

82 Taylor, Villages, 139-140.

${ }^{83}$ Doc Coleman, according to his obituary, established seven Holiness Churches.

${ }^{84}$ Taylor, Villages, 34. 
${ }^{85}$ Ibid.

${ }^{86}$ Raymond A. Mohl, "Miami's Metropolitan Government; Retrospect and Prospect," Florida Historical Quarterly, LXIII no. 1 (July 1989), 28-29.

${ }^{87}$ A county-wide public health department was created in 1943, the Dade County Port Authority was created, placing airports and seaports under County control in 1945, and Jackson Memorial Hospital was transferred to the County in 1949. (Mohl, "Miami's Metropolitan Government, 28).

${ }^{88}$ Mohl, "Miami’s Metropolitan Government;" Gary R. Mormino, "Midas Returns; Miami Goes to War, 1941-1945," Tequesta, LVII ((1997); Howard Kleinberg, "Miami: The Way we Were: Perrine's legal life lasted a year," Miami News, 20, August $1988,4 \mathrm{C}$.

${ }^{89}$ Transcripts from Miami's incorporation meetings show that blacks were not simply enlisted as voters, but actually spoke at the meetings (George, "Colored Town").

${ }^{90}$ Maxine D. Jones, "The African-American Experience in Twentieth-Century Florida," in Michael Gannon, ed., The New History of Florida, (Gainsville: University Press of Florida, 1996), 373-390.

${ }^{91}$ Prior to this election there had been only fifty blacks who voted at any given time. (Dunn, Black Miami, 192-195); The current mayor, E. G. Sewell reflected that ironically, it was his brother, John Sewell, who, in 1896, was responsible for allowing black political participation in order to obtain the required number of votes to incorporate Miami as a city. "Negro Vote is Cast Under Heavy Police Guard," Miami Herald May 3, 1939.

92 "Plan Defended by Overstreet: Calls "Negro Ward" Criticism "Smoke Screen" of Opponents," Miami Herald October 23, 1939.

${ }^{93}$ Taylor, Villages, 58.

${ }^{94}$ Taylor, Villages, 58.

${ }^{95}$ Bishop and Mrs. Ingraham interview, April 2002.

${ }^{96}$ Bishop and Mrs. Ingraham interview, April 2002.

${ }^{97}$ Miami Herald, 21 Nov. 1948; "286 Irate Late Registrants Swell Perrine Voting Total," Redland District News, (Redland, Fla.) 19 Nov. 1948.

98"Jew Store" was a common name given by Southerners to stores owned by Jews. According to Ingraham, the owners of the Jew Store stayed "out of politics." 
${ }^{99}$ Joseph Ingraham heard about the barricade the following day, and also many years later when he performed Doc Coleman's funeral. He related that when he reiterated Doc Coleman's life, as is the custom at black funerals, a gentleman came forward to testify that he was one of the Masons who stood guard on Homestead Ave. waiting for the Klan. (Ingraham interview, April 2002).

${ }^{100}$ Charles Fernandez, "Perrine Negro Candidate Flees Town: GOP Leaders Claim Threat of Death, Fire," Miami Herald, 23 Nov. 1948; "446 Perrine Voters Pick New commissioners," Redland District News, 3 Dec. 1948; "Probe of Candidate's Withdrawal Continues," Miami Herald, 25 Nov., 1948; Charles Fernandez, "Ben Shavis Denies Life Threat," Miami Herald, 24 Nov. 1948; "Perrine Quiet on Election Eve," Redland District News, 26 Nov.1948; Milt Sosin, "Perrine Furor Brings Offers of Resignation," Miami Daily News, 22 Feb. 1949.

${ }^{101}$ The Miami Herald, Nov. 24, 1948.

${ }^{102}$ Elsewhere in Miami, the police were not supportive of the black community, and sanctioned the Klan's activities. See Paul S. George, "Policing Miami's Black Community, 1896-1930," Florida Historical Quarterly, Vol. LVIII No. 4 (April 1979)

${ }^{103}$ Blacks were not allowed to register as Democratic party members until 1946 so at the time of the Perrine voter registration, the Republican Party, which had accepted black voter registration over the years had built up a support base among those blacks who were involved politically. Since the 1960 's, black voters have identified with goals of the Democratic party, and from that time on, have overwhelmingly registered as Democrats. It must have seemed inconceivable to some that Shavis was a registered Republican. Variations of the Incorporation Story from Archie Finkley interview, February 2002; Fannie Mae and Sinclair Williams interview, March 2002; Bishop Ingraham, interview, January 2003; Shirley Green interview, March 2001.

${ }^{104}$ According to Marvin Dunn, Miami may have been the first city in the South to hire blacks as members of its permanent police force. In 1944, under extreme secrecy, five black men were sworn in as police officers of the Miami Police Department. It was not until 1963 that Miami's black police officers could arrest whites. (Dunn, Black Miami, 172-173).

${ }^{105}$ Other historians, including Clayton and Drake in their landmark study of Chicago's "Black Metropolis," also wrote of men whom they called "race men," those men who before the civil rights era, worked to advance the interests of the black race. (St. Clair Drake and Horace R. Cayton, Black Metropolis: A Study of Negro Life in a Northern City, [New York: Harper and Row, 1945]).

${ }^{106}$ Dunn, Black Miami, 171. 


\section{IV: Perrine's Civic Social Capital Declines: 1948-1980}

The events surrounding the incorporation of Perrine marked a watershed in the history of Perrine. Other major cities throughout America after World War II either were becoming centers of large metropolitan areas or dealing with rapid suburbanization, and

Miami was no exception. For Perrine, this new era would witness increased segregation and isolation. As the farming industry gradually disappeared and housing and businesses began to take its place, Perrine was absorbed into the larger metropolitan governmental structure and many blacks lost meaningful contact with whites.

The failed incorporation coincided with the end of WWII, ushering in a era of massive social and political changes. Large scale migrations throughout the country brought together diverse populations from different parts of the country and with them an infusion of new racial attitudes and experiences. The country's political fabric was beginning to stretch as excluded groups (the first of these groups included blacks, Jews and Catholics) demanded inclusion into its tightly guarded system. Soon integration would come to be generally accepted as the way to achieve civil rights for blacks. Other challenges to traditional ways of life would follow in the succeeding decades.

\section{Departure of the Agricultural Industry: Perrine's Bi-racial Network Dismantled}

After the town of Perrine was abolished, many white growers began to sell their farmlands and move away, a trend that would continue over the next decade as increased residential building began to replace farming. There were a number of reasons for the 
departure of the agriculture industry in the Perrine area. Some growers involved in the incorporation of Perrine were disappointed and disgusted that their lifelong contributions toward the building of Perrine had ended by the failure of the larger community to support its new government, and that they had been edged out of the political equation. The restructuring of the metropolitan political system had rendered the white growers' civic social capital obsolete. A second reason was that a few of the important growers died in the late 1940's: Robert Kerr died in 1948, Lamar Paxson in 1948 and Mac Hagen around the same time. ${ }^{1}$ Finally, the demand for housing due to an increased population, especially after the War, drove land prices to levels where it was more profitable to sell than to endure the hardships of farming.

As the white growers began to leave, blacks in what was now called West Perrine, became isolated. This isolation was reinforced by the widening of Highway US 1, which had been built alongside the railroad some years earlier, and which had served to separate black from white Perrine throughout the century. New zoning decisions by the Dade County Board of Commissioners provided the framework within which the official segregation of West Perrine would be completed. West Perrine emerged as part of a vast suburbia, a black enclave with overwhelmingly white neighborhoods developing to its east and south.

The failure of Perrine's incorporation meant a dismantling of the bi-racial network that had served to hold Perrine together for a half-century and this led in turn to a decline in civic social capital over the next thirty years. When Perrine's whites pulled out, black Perrine's ties to white society were severed. Loss of contact with whites meant a cutoff in the information flow between the races. Without contact, the longstanding 
trust that had developed between blacks and whites lacked the wherewithal for renewal. As blacks in Perrine were forced to rely on strong ties, their community became more insular. Ironically, blacks in Perrine were becoming more isolated at a time during which blacks across the country were beginning to experience greater inclusion into the wider society.

\section{Residential segregation in South Dade}

One of the consequences of the loss of Perrine's inter-racial alliance was that Perrine's blacks were now at the mercy of an unchecked greed on the part of the banking and real estate industry, which made use of federal programs to carry out their own agendas. Large numbers of blacks and whites relocating to Miami during the late 1930's and 1940 's, and especially after the war led to a massive wave of home construction in

\section{South Dade. ${ }^{2}$ This new development continued the pattern of strict residential} segregation that had been initiated over fifty years earlier, reinforced by KKK violence, and sustained throughout the years by a series of racially-motivated public policy decisions by local government agencies, some of which utilized federal programs. Some of these policies included the establishment of a "color line" in the early decades that limited blacks residentially to a confined area of Miami, called Color Town (later called Overtown), "New Deal" funding for public housing projects that allowed businessmen to move blacks from Colored Town into new segregated neighborhoods, ${ }^{4}$ and "redlining," a discriminatory lending system developed by the federal Home Owners Loan Corporation (HOLC). 
This last policy had far-reaching effects on Dade County's future development, consigning certain residential areas, including Perrine, to a "future of physical deterioration and insularity due to fixed segregation," as historian Raymond Mohl has shown. ${ }^{5}$ HOLC was established in 1933, in the midst of the Depression. It was designed to grant long-term, low-interest mortgages to homeowners who could not secure regular mortgages or who were in danger of losing their homes through default or foreclosure. What began as a part of a relief package evolved into an elaborate appraisal and rating system, ranking areas according to desirability. But the HOLC appraisal committees that determined the rankings were comprised of local bankers and real-estate men and the rankings reflected the racial biases of the time. Consequently, those areas where blacks lived, along with areas nearby them received the lowest ratings. These appraisal categories were adopted by the private banking and mortgage industry in a practice called "redlining," whereby banks and other lending institutions refused to grant mortgages and other loans to those wishing to buy in older, poorer, and minority neighborhoods. In addition to appraising existing neighborhoods, the committee also designated extensive areas of undeveloped land for future black development. By 1938, most of Dade County had already been redlined along racial lines.

The Dade County Board of County Commissioners, through the Planning and Zoning Board (originally called the Planning Board), used the HOLC appraisal and mapping system in overseeing the expansion of lands, assigning black residential growth to areas already redlined as less desirable by the HOLC appraisers. ${ }^{6}$ One example of a zoning decision based on a Zoning Board's recommendation was a 1941 ruling that a tract of land in Goulds (just south of Perrine), "be segregated and set aside for colored 
occupancy." In 1944, in another decision concerning Goulds, the commission approved a resolution establishing a boundary line, "dividing White and Colored residents, in the town of Goulds." In August 1945, a zoning resolution made explicit the Commission's intentions. It directed that "People of the White race should not be permitted to encroach upon the areas which have been designated for Negro occupancy, nor should Negro Occupancy be extended into areas heretofore designated for White occupancy" and the "boundaries heretofore approved by this Board, or as the same shall be hereafter amended or altered, shall constitute the dividing line between the White and Colored people in Dade County, Florida." 7

These zoning decisions had a negative impact on race relations, encouraging blacks and whites to act as adversaries as they competed with each other for land. MLC records show evidence of this process. In Perrine, racial tensions began to develop when whites feared the devaluation of their property if blacks owned land too close to their land. By the mid 1940's many of the lots in Perrine that the Model Land Company had platted in 1903 had been sold. There were no blacks living in the white sections but a few whites, among them some of the larger growers, lived west of the railroad adjoining the colored section. In a letter dated Feb. 9, 1943, MLC land agent Frank J. Pepper wrote to the parent company in St. Augustine, Florida that blacks were refusing to buy a certain property the MLC was offering for sale in the colored section that abutted white land because they were being threatened by whites if they bought it. The issue was resolved by one of Perrine's white growers, Cecil Barber, buying the property at a discount. ${ }^{8}$

A second example shows that, eleven years later in 1952, the residential landscape in South Dade was still being disputed. This example concerns a boundary that a white 
property owner wanted established to separate white property from the new Richmond Heights housing project just north of Perrine, that, a few years before, had been re-zoned for black development This property owner petitioned MCL land agent Frank J. Pepper to endorse the re-zoning of his land, which fronted Coral Reef Road, for business use, saying that "since none of the property South of Coral Reef Drive is zoned for colored residences at this time, a business property North of Coral Reef Road would act more or less as a neutral buffer. This is especially so when you consider that white ownership of this business property is practically assured."

\section{Richmond Heights: Seeds of Civic Social Capital Planted}

In April 1946, the Florida Supreme Court issued an historic ruling, overturning a 1937 act that gave Dade County the power to segregate black residential districts. This attempt to de-legitimize Southern racial conduct did not reflect local sentiment on racial issues, but instead followed a stream of federal court rulings which determined that racially segregated housing was unconstitutional. In Miami white residents opposed efforts by blacks to move into what had been historically white neighborhoods, and longstanding institutional mechanisms, such as redlining, kept continuing segregated patterns firmly in place. ${ }^{10}$

An editorial in the Miami Herald shortly after the Florida Supreme Court decision urged new legislation to force a resolution to the "negro problem" : "[Legislators] must seek new ways of improving the living conditions of the Negroes, as well as ease the objections of white residents. Our negro problem is the white man's responsibility. It 
has, and continues, to grow more acute each year. There is no issue of White Supremacy, nor social equality involved. It is a matter of self-preservation, decency and humane conduct."11 But by the late 1940's city planners continued along the same lines they had employed since the 1930's: slum clearance of Miami's overcrowded inner city by the relocation of blacks to outlying areas. ${ }^{12}$ The Florida Supreme Court ruling notwithstanding, the County Zoning Commission still had the power to approve black development and it continued to do so in accordance with its previous segregated agendas.

There was one unprecedented change in policy, however. In an auspicious decision, the County Zoning Commission, in 1949, approved hundreds of acres of additional land just north of Perrine, land originally intended for white development, for the Negro Housing Development of Richmond Heights. ${ }^{13}$ The creation of Richmond Heights, a modern, planned community, originally intended for black veterans, but later opened to black professionals, would become the locus for the accumulation of civic social capital by many of South Dade's blacks. And it would be the leaders from this community, who in the 1980 's, would come to the rescue of its ailing neighbor, Perrine, just to its south.

Because Richmond Heights would come to play such an important role in Perrine's later history, it is worthwhile to describe the fertile grounds from which Richmond Heights' civic social capital would emerge. Richmond Heights was the brainchild of Pan American pilot Frank C. Martin, who had flown over the pine-lands of South Florida for twenty years on the Miami/Havana route. Martin had begun buying land from the Model Land Company and the Perrine Grant Company through the 1940's until, by 
1949, he had accumulated about 2200 acres. He "improved" some of his earlier holdings with fruit groves, but in 1949 , realizing that housing would provide the greater return on his investment, he decided to create a housing developing for blacks.

Martin's motivation for building a development for blacks, rather than whites, remains unknown, and he must have gone to considerable lengths to obtain the zoning changes necessary for his project. Clearly, without the new G.I. Bill of Rights, which provided low mortgages, job training, education, and health benefits he would not have been able realize this venture. What is important to the discussion concerning the generation of civic social capital is the integrity that Martin displayed in developing his project and consequently, the degree of trust and good will that this fostered between whites and blacks. Scorning the "get in and get out" mentality of other developers, Martin endeavored to create a "community, rather than just a project," as one writer commented. He planned for an enduring community, with well built single-family two and three bedroom homes of CBS construction, modern conveniences, and an emphasis on neighborhood beautification. He anticipated future building code requirements by building sidewalks, wide streets, and a water main. His plat reserved a large tract for a playground and recreational park, four sites for churches, fifteen acres for a school, and other sites for a future medical clinic, a large shopping center complex, an industrial park, and utilities facilities. Martin's pre-planned community was the first and largest private housing development built exclusively for black veterans. One writer remarked that Martin's "outstanding experiment in Negro home ownership. . may be the outstanding example in the entire South."14 
Operating within the confines of a dominant white "system" that still mandated segregated neighborhoods, Martin came to the same conclusion as did Flagler in initiating Model Land Company policies: that providing a stable environment in which blacks could own good homes and take pride in their neighborhoods would both benefit blacks and be profitable, in the long run, for business. With this dual objective in mind, Martin screened prospective buyers, selling homes only to those who could show that they could make the mortgage payments (VA financing required $\$ 25$ as a down payment). The original list of buyers showed "some sixty school teachers, including a principal and a doctor of philosophy; ten policemen, including the only Negro detective on the Miami police force; nine registered nurses, one dentist, thirty-eight post office employees and a score of Veterans Administration employees." 15

In planning Richmond Heights, Martin established ties with a host of black civic leaders in Miami, including two prominent church figures, the Rev. Theodore R. Gibson of Christ Church in Coconut Grove and the Rev. Edward T. Graham of Mt. Zion Baptist Church in Overtown (formerly Colored Town). ${ }^{16}$ Rev. Gibson, of Bahamian descent, was already, in the late 1940's, involved in a bi-racial coalition, which included white community activist, Elizabeth Virrick, to eradicate slum conditions in Coconut Grove. ${ }^{17}$ This coaliton was a significant force in opposing the cartel of real estate developers, made up of private builders and slum-lords, who supported segregated residential policies. It is reasonable to assume that Rev. Gibson and other blacks that Martin consulted, through their association with Virrick, possessed a significant level of civic social capital. Although it is unknown exactly what part Martin's association with Miami's black civic activists may have played in the planning of Richmond Heights or in 
persuading the Miami Board of Commissioners to open this large tract of land for black development, it may be assumed that this association likely added political weight to Martin's position. Even the Racial Relations Service, an agency created in 1938 as a branch of the U.S. Housing Authority to provide advice on racial issues to federal and local housing authorities, through the efforts of its black chief, Frank S. Horne, was unsuccessful in achieving integrated housing in Miami. This agency did, however, play a part in persuading the Dade County Commissioners to open up the Richmond Heights site for black development. ${ }^{18}$

Tragically, Frank C. Martin's life was cut short, a victim of a traffic fatality, less than two years after he began building. At the time of his death, he had completed and sold 457 houses, and was in the process of building another 275 homes. ${ }^{19}$

A letter written to MLC Vice President, Carl W. Hawkins by his land agent, Frank J.Pepper, who had worked with Martin for years as Martin built up his real-estate holdings, sheds some light on the warm feelings and bonds of trust that had developed between Martin and the black families to whom he sold homes: Pepper wrote in reference to Martin's funeral at St. Stephen's Episcopal Church in Coconut Grove which he attended: "The church was crowded beyond capacity, and I was very much impressed in noticing that at least half of the gathering was composed of nicely dressed and intelligentlooking colored people, many of them with their entire family of children. To my mind, this was a wonderful tribute to the character of Mr. Martin and the type of work he was doing in developing, not so much for his own profit, but for the satisfaction he received and the pride he had in doing something to help the other fellow who was willing to try to help himself." ${ }^{, 20}$ In an article five days after Martin's death, John Bills wrote that Martin 
"was no crusader, no professional or amateur bleeding heart. He was a practical businessman who had learned a great truth from the transformations which he saw in every Negro family that bought in Richmond Heights." ${ }^{21}$ Black residents of Richmond Heights would show their appreciation to Martin by naming one of their churches, Martin Memorial.

Thus, were the seeds sown for civic social capital to flourish in the new middle class black neighborhood of Richmond Heights. Even in the planning stages, networks were established between white businessmen and Miami's black elite, networks that were beginning to be used to challenge some of the broader forces that excluded blacks from full participation in Miami's white-dominated social system. Indeed, in a Miami Herald article dated Jan. 9, 1955 about George M. Davidson, a developer who was continuing Martin's project, it was noted that Davidson "is working in cooperation with Negro leaders in his plan for extension of Richmond Heights," among them, H. Daniel Lang of the Greater Miami Urban League. ${ }^{22}$

As can be seen by the initial list of home buyers' occupations, many were, by nature of their jobs, already partially involved in the wider white society. Although segregated residentially, their professions as teachers, nurses, and policemen, would bring them by virtue of their professional lives, into close contact with whites. These "weak ties" that blacks from the community of Richmond Heights would form with whites in the wider society during these early years of integration would form the ground from which their civic social capital would develop.

Martin's vision for an enduring and stable community would be actualized in the years to come as many blacks in the greater Miami area were drawn to Richmond 
Heights, seeing it as a desirable place to live and to raise their families. Although full integration was still many years away ${ }^{23}$ (for example school integration in South Dade County would not occur until 1966), Martin provided blacks the foundation on which to build a power base by offering them a piece of the American dream - good homes in a good neighborhood. He said, "Give these people a chance to live in decent, clean homes and surroundings and they will work out their own destiny." 24 Indeed, the plans Martin laid out for a lasting community, including well constructed modern buildings, parks, and plots reserved for schools, churches, shopping centers, medical centers, etc., insured that Richmond Heights would not suffer the plight of other segregated urban areas, like its neighbor Perrine, to the south. Quality of life issues and economic advancement would become the banner of a new generation of black leaders emerging from Richmond Heights as the era of integration commenced.

The Richmond Heights undertaking, shows how a federal policy, i.e. the G.I. Bill of Rights, was utilized by a coalition of individuals and groups to maximize benefits to blacks over the long term. As has been shown in the case of the use of the Depressionera appraisal and rating system developed by HOLC, this was not always the case in Miami. This federal policy was used by city planners to increase the wealth of a small group of white businessmen (with benefits extending to whites) at the expense of the black population, whose property was devalued. This loss of wealth would eventually result in physical deterioration of black residential areas and all that accompanies such areas - crime, poverty, hopelessness, etc.

The building of Richmond Heights represented a high level of civic social capital because the participants themselves - Martin, Verrick's coalition, the land agents 
of the Model Land Company, and the black residents of South Dade - shared a set of similar values - those very same "republican virtues" of self-discipline, self-control, and self-reliance about which the American Founding Fathers spoke, and a vision for their society that extended the "radius of trust" beyond that of their immediate circle. This joint purpose allowed them to work out a strategy for inclusion of blacks into society, albeit within the confines of the Southern racial structure, based on the shared principles of hard work, self-determination, and dignity. Unlike the bankers and real-estate men who had used the Depression-era appraisal and rating system for their own benefit, this group made use of the G.I. Bill to include, not to exclude, and to look to the future with their plans, rather than to try to cash in on short term profits.

\section{Generational Rift Contributes to Increasing Isolation of Perrine}

Veterans Administration loans proved a boon to hundreds of thousands of returning GI's, many of whom ordinarily might not have been able to afford to own their own homes. Many VA housing projects were built in black areas in Dade County after the War. Some of Perrine's returning veterans bought homes in the Richmond Heights development and became a part of that newer community. Others bought homes in the new VA insured housing project in a section of West Perrine. ${ }^{25}$

Some returning veterans reflected new attitudes that were beginning to take shape nationally regarding desegregation. The War had engendered a national unity of purpose between blacks and whites at home (war drives were organized in Colored Town) and in the service. When blacks returned home they expected that rights and privileges be 
extended to them also, since they, as Americans, fought world powers on behalf of American principles. In addition army life had brought blacks from Perrine into contact with Americans from diverse backgrounds and they were exposed to novel approaches to old problems. Service oversees brought blacks into contact with cultures that treated blacks and whites as equals. Adopting a new attitude, one that threatened to undermine the efforts of the older generation, these returning veterans sought more inclusion into the wider society. Bishop Ingraham recalled his shock at the veterans' new attitudes: 'Oh, they came home doing unbelievable things." Like, "go'in cross the highway and want to sit in a restaurant, and want to buy a sandwich in a [white] restaurant or something like that." That would be unthinkable for the older generation: "We wouldn't do that. . But when they came from the service they started doing things. They started changing. They wasn't taking it. But we were accustomed to what we were doing and we were caught up in what we were dong. And we were satisfied." ${ }^{, 26}$ The framework within which Perrine's leaders had operated to successfully sustain their community, seemed outmoded to the younger generation of returning veterans. But by challenging the methods the older generation had employed in dealing with racial inequality, the younger generation also challenged their parents' authority. This would be the first in a series of breaches that would distance the generations throughout the succeeding decades.

The leaders of the older community of Perrine would take a different approach to the new era now unfolding, one that would further Perrine's isolation. Segregation had worked for them well enough over the last half-century. Acutely aware that the white social system placed blacks at an unfair disadvantage in relation to whites, and that black attainment of wealth, education, and material quality of life was thus limited, the Perrine 
community had turned their attentions inward, fashioning a rich communal life centered around home and the church. Homestead Avenue had become a cultural center for black farm workers throughout the entire South Dade County. It was lined with black mom and pop stores, numerous juke joints, and a theater and it drew large crowds on the weekends. Highly resourceful communal leaders had basically built Perrine with their bare hands their homes, their churches, and many of their roads. They had found innovative solutions for educational and policing deficiencies. They had even been willing to experiment with a formal attempt at integration, but they had seen what had happened when they had attempted to mix into "white people's business." These older leaders decided to continue the strategy of segregation that served them relatively well during the first half-century of Perrine's history.

\section{Post WWII Race Relations}

Contact with whites after the War, and continuing through much of the 1960's, came by way of working outside of Perrine, in the white world, making Perrine a working class neighborhood. Many men, accustomed to building their own houses, looked to work in the construction jobs that were opening up due to increased building, but racial discrimination prevented access to many of them. In the 1950's blacks were not permitted to work on jobs in white areas. Technically they should have been able to work on public housing projects being built in black areas, but the labor unions demanded hiring only union workers, and the labor unions excluded blacks, and so they were locked out of these jobs as well. Eventually blacks began organizing black unions 
but it was not until the 1960 s that blacks were admitted to most trade unions. ${ }^{27}$

Government jobs, however, were open to blacks. Residents of Perrine worked on road crews widening US 1, and in building the new Homestead Air Force Base. ${ }^{28}$ Often women took jobs as domestics and nannies for white families. Many returning veterans took advantage of the vocational training the GI Bill provided, and took jobs in the service industry. Many of these veterans, however, like John Bruton, who trained as an air conditioner repairman, were disappointed by unfair treatment at home after the optimism they felt during the war that blacks would receive equal treatment. Bruton eventually left his job because he was paid considerably less than white repairmen. ${ }^{29}$

Mrs. Ingraham described what it was like going to and from work on the privately run Florida Motor Line, the only bus line that went as far as Perrine. "So when we would be at the bus station in Miami, we would pay the same fare. But sometimes two buses might be standing right there. The driver would get on the bus and he would turn his back to all of the black people and he would let all the white ones on. And he would leave two seats in the back... And then came the line. So now, as many could sit on those seats, how many could stand could stand. But if your feet, see I'm not telling you something that was told to me. I'm telling you what I know. If your feet touch over that white line that was drawn in the bus, you had to get out. Where you work all day long. One bus has already gone. You got to get home to tend to your children, and cook and bathe them and what not get them ready for school. Stay up till twelve or whatever time, and help them with their lessons just like everyone else but that's just the way it was." ${ }^{30}$ It wasn't until 1957 that a federal judge ruled that bus segregation laws and ordinances in Florida were unconstitutional. ${ }^{31}$ 
Perrine's blacks confronted segregated restrooms, water fountains, and bus terminals when they ventured into the white world. They were denied entry altogether to restaurants, hotels, and movie theaters and were not permitted to try on clothing in department stores. ${ }^{32}$ Social and job discrimination would begin to ease during the 1960 's Lacking meaningful personal relationships with whites during this time, and finding instead a wall of discrimination, blacks in Perrine focused their attention on their own community. Communal leaders helped people navigate the new restrictive building codes that made building more complicated. Doc Coleman helped families by wiring their homes for electricity and others helped their neighbors to comply with the building codes. Builders, including William Mathews constructed buildings on what would be a new business street. Ben Shavis started the first garbage pickup service in West Perrine. Churches held revivals, barbeques and sing-ins. The Masons held "turnouts." People found that their vegetable gardens and the bay and canals where they fished provided enough to eat. Churches helped those who were in need.. ${ }^{33}$

Communal social controls were enforced by church attendance, which was widespread among the thick network of families that made up the majority of Perrine's residents. Churches had varying responses to the social ills that plagued the community, ills associated with drinking and the weakening of families due to out-of-wedlock children. But Bahamian churches maintained tighter controls than did African-American congregations. They kept a tighter rein on their children. Their younger generation was less likely to go against their elders' wishes, less likely to elope or to marry nonBahamians or to have children out-of-wedlock than American blacks. ${ }^{34}$ 


\section{Perrine's Participation in the National Civil Rights Movement}

The modern civil rights movement is usually thought of as beginning in the mid1950's, marked by the 1954 U.S. Supreme Court decision in Brown v. the Board of Education outlawing school segregation and the 1955-56 Montgomery, Alabama bus boycott and culminating in the 1960's when the movement became more radical and Congress enacted important civil rights legislation, including the Civil Rights Act of 1964 and the Voting Rights Act of 1965. Examples cited in this thesis and elsewhere, however, have pointed to a much longer history of civil rights involvement in Dade County. To this has been added a growing body of research chronicling local civil rights struggles in other regions, leading historians to suggest, as has Raymond Mohl in South of the South "many different civil rights movements, rather than a single unified movement with a common agenda." 35 These "movements" may be characterized as a variety of grassroots efforts, their differences dependent on the conditions of individual local environments. Together these separate movements formed the substrata on which the modern movement would develop.

The national "civil rights movement" as it began to emerge in the 1950's and 1960 's, was able to mobilize a diverse group of Americans around a single cause. The images of the civil rights struggle - pictures of non-violent protests, coupled with instances of police brutality- beamed into homes across America, awakened a deep sense of unfairness among many. The Rev. Martin Luther King Jr., more than any politician of his time, appealed to the convictions of many Americans who believed that America was being untrue to the ideals on which it was founded. Using the religious/political language 
of the national culture, King invoked the image of God who had acted in Israel's history and declared that now God was acting in America's: "God had decided to use Montgomery as the proving ground for the struggle and triumph of freedom and justice in America. ${ }^{36}$ King made popular a new form of political activism, non-violent resistance, which became a hallmark of his strategy to achieve racial equality and integration.

Nationally; the civil rights movement engendered a significant degree of bi-racial cooperation, but in Miami, there were few bi-racial coalitions generated by the movement itself, and these included newly arrived whites from the North. In Miami, the civil rights movement coincided with a massive demographic change, bringing in large numbers of whites and blacks from the North, and then in 1959, tens of thousands of Cubans fleeing the Cuban revolution. The civil rights struggle in Miami became much more complex at this point. As blacks were struggling for the rights and opportunities long denied to them and awaiting the economic rewards this would brings, suddenly an influx of immigrants stood to snatch the prize they had almost won. ${ }^{37}$ Another sizable group, Jewish newcomers from northern states also sought inclusion as they faced residential, job, and educational discrimination. Of this group, a small left-leaning faction with ideological ties to northern labor union activism and progressive and communist organizations became leading civil rights activists. They formed bi-racial coalitions with several leading local black pastors who had been politically active in Miami for decades, and a small number of black activists (one such activist was James Nimmo, also with left leaning affiliations. Nimmo, as will be recalled, had been the leader of the UNIA's Black legion in the 1920's). One of these bi-racial organizations, made up of mostly Jewish members, was Miami's local chapter of CORE, which spearheaded lunch counter eat-ins 
in $1959 .{ }^{38}$ Fierce anti-communism (which often masked underlying racial prejudice ${ }^{39}$ and anti-Semitism) hampered the potential support from other sympathetic Jewish groups and politicians. ${ }^{40}$ Eventually, the combined efforts of black and bi-racial activist groups came to fruition in 1960 when white businessman John Turner negotiated an end to segregated public facilities. The negotiations involved a series of meetings with leading black ministers, white businessmen, Florida Governor Collins and Miami Mayor Robert King High. ${ }^{41}$ The lunch-counter activists had evidently made enough noise to convince the Governor, Mayor, and local civic leaders that Miami's national image and lucrative tourist trade would be compromised if they did not find a timely resolution to the city's racial unrest.

It is within the context of the national civil rights movement that the local "movement" in Perrine must be placed. Certainly the efforts of Perrine's community to get the School Board to approve a school for black children in the 1920 's, and the attempt to form and maintain a legally sanctioned bi-racial government in 1948 (not to mention the general influence local blacks exerted in Frank C. Martin's decision to build Richmond Heights), rank highly in the annals of civil rights achievements in Dade County and the South. These achievements all occurred in the years before the national civil rights movement began But integration as a way to civil rights, which was the hallmark of the national movement, was not a strategy that leaders in Perrine embraced. According to Marvin Dunn, the Rev. Martin Luther King's Southern Christian Leadership Conference, which was active in many other Southern cities, did not have a branch in Miami, although a few of Miami's black leaders did participate with King elsewhere and they brought him to Miami twice. ${ }^{42}$ When news King was organizing 
churches to demonstrate against segregation and injustice reached Perrine, it did not find much support among Perrine's church leaders. Bishop Ingraham, for one, did not want to be a part of white society but he felt that there should be equality between the races and fair treatment towards blacks. He did not conclude, however, along with others in the movement, that whites had an unfair advantage over blacks. His primary concern was for his country, America, which he loved, and the belief that having two sets of services, one for whites, and the other for blacks was wasteful. When asked how he felt about King's message he said, "I felt very reserved. . Why at this time that somebody would feel that they are better than somebody else. Or why is it there must be two standards of everything. Why spend so much, that's just the way I felt about it now. Just wastes money now. . Being part of white wasn't part of me because I thought we were all, I thought we were all people. I never felt too much they had everything, but to feel that they were super humans. No, they were not super humans. . I would like to be equal with them. . I would like to be treated fairly." Looking at the waste he said, "I looked beyond that and I looked at the part, this being thrown away. Why can't this be utilized to make a bigger country, to make a better country.,"43

His wife disagreed with King's idea of passive resistance and non-violence. She said, "I remember a statement that was made, you know, they wanted people, campaign for people get in the marches what have you. And they made it clearly, if you wasn't able to be in the march and accept what was going on without retaliating. . backlash. Regardless of how many dogs they would sick on you or if they would turn water on you, you wasn't supposed to fight back. So I know that wasn't me, so wasn't no use getting 
into it. . So that statement was made clear and I believe that was what kept a lot of blacks from joining cause they know they character. So they would get into it."

\section{Perrine's Churches Confront the Social and Economic Challenges of the Post-World War Era}

In the ensuing decades, Perrine's churches encountered new challenges that would tax their ability to meet their community's needs. The first palpable effects of integration came to Perrine by way of its youth, through school desegregation (1966) and returning servicemen from the Viet Nam War. Beginning at a disadvantage because of their extreme isolation from white society, Perrine's churches were unprepared to help their youth navigate the white world, one that was undergoing massive social changes itself. Churches could not foresee what cultural attitudes and values their children would encounter and what effects they might have on Perrine's community.

The community was also challenged by the need to integrate new populations, including blacks from Miami's slum areas of Overtown and Liberty City, for whom the first of several public housing projects was built in the old Kerr's Quarters for black farm workers in the late1950's. A new wave of black immigrants also would arrive from the Caribbean, South America, and Africa in the 1970's to complete a picture of ethnic diversity in Perrine and pose a challenge to Perrine's cohesion. The signs of declining civic social capital would appear in the form of poverty, crime, urban decay, drug use, and the dependency of many of its citizens on the welfare system and would complete the list of challenges to Perrine's churches. 


\section{School Desegregation: 1966}

The desegregation of public education in Dade County was probably the most difficult of the racial barriers to break. The Dade County School Board resisted the 1954 Brown v. Board of Education U.S. Supreme Court decision, which ordered a halt to racial segregation of public schools, as long as it could. Finally political pressure by both black and white groups left them no choice but to integrate. Implementing this decision was another matter. The first attempt occurred in 1959, when the Dade County School Board announced that Orchard Villa Elementary School, serving a neighborhood undergoing a racial transition, would open in the fall as an integrated school. But by the time the school year began less than a dozen white students remained. By mid-year Orchard Villa was an all-black school. In 1960 a voluntary desegregation approach was tried, without much success. Finally in 1964 the U.S. Congress passed legislation that gave the federal government a way to punish states for not desegregating, and rewarded school districts that complied with desegregation. This bill provided the impetus for an increase in the rate of school desegregation in Dade County. By the late 1960's all but sixteen schools remained all-black, but as late as the 1990's full integration had still not occurred. The greatest impediment to school de-segregation was Dade County's housing patterns. Despite official residential integration, at the end of the twentieth century blacks and whites (and other ethnicities that arrived in later years) still resided according to the segregated design set up in the County's early decades. ${ }^{45}$

When schools in South Dade were desegregated in1966, Perrine's church-oriented community, one that had long maintained a protective watch over its children, keeping 
them close to home and church, viewed the safety of their children as its primary concern. Shirley Green, of Bahamian descent, was sixteen years old and among the first class to attend a white high school after school desegregation. She related how her black teachers had tried to prepare her class for the white world: "White people, they don't talk loud. Okay? And if you talk loudly, you are going to frighten them. And then they'll think you're acting bad. ... And the whites didn't want you to look them in the eye. So we had to be re-taught." This last point was directed mostly towards the Bahamians, for according to Green and others, "The Bahamians are known to be more assertive, more aggressive than the American blacks. So in most situations Bahamians tend either to get into trouble, or to be more successful." ${ }^{, 6}$ According to oral histories, in the mid-sixties, there were still clear distinctions between Bahamian and American blacks. ${ }^{47}$

Shirley Green's description of what it was like for her to see white people at close range for the first time in her life illustrates the enormous gulf between Perrine and the white world in the mid-1960's. "We had a lot of shocks because we had never been around white people before. We had only seen them on t.v. So, we like said things like, I thought all white women dressed up. I thought they always had high heels on. You know. For somebody who only sees a person through the media, it's very strange. You're supposed to be sitting there learning and you're looking at this person and saying, what color is her hair? Is she blond? No, blond is yellow. . We were just trying to figure out another thing about skin complexion. I thought they were white. They're not white. They're kind of pink. Pink. What shade of pink?"48

Green described her first experiences at a white school as horrible, "because at Palmetto [high school] you could raise your hand in class. You were totally ignored. 
You got no answers from the teachers. No discussion. Nothing. You were just a shadow. You were non-existent. It was the most horrible time that we had ever, ever, experienced." To make problems worse for the Perrine children, after the first year of desegregation, the School Board decided to move the black high school children to a different high school. The following year, when the School Board tried to move the children again, Perrine's churches stepped in, calling a community meeting and protesting the move in what Green described as church "activism that was political strategy." The churches won a partial victory; graduating seniors were permitted to remain at their school. ${ }^{49}$

\section{Churches are Unable to Help Young People Interpret White Culture}

Perrine's churches, functioning as did black churches elsewhere in America, had always acted as brokers between black and white society, helping their community interpret and negotiate outside events and situations. When integration reached Perrine, its youth encountered a white culture that was in the midst of great social change itself. In the wake of what was commonly termed the " 60 's revolution" white youth were expressing new attitudes concerning freedom, rebellion against authority, antiestablishment sentiments, notions of sexual liberation, and new ideas about drug use. Generational and ideological divides had developed in the broader society, engendering conflicts that threatened to tear apart the existing social fabric of America.

Perrine's churches were slow to understand what was happening to their youth because of their isolation from white society. Their contact with the broader society prior 
to this period had been in the context of obtaining goods, services and opportunities denied them as members of a discriminated social group. Lacking experience with the white world, and not understanding the great changes that were occurring there, church leaders were unable to draw on their rich religious resources to help the younger generation, who were ultimately left to confront new attitudes and values by itself. It would be years before churches would begin to develop an understanding that many of these influences had and would continue to have negative effects on Perrine's children, and it would be decades before they would begin to devise meaningful strategies to confront them.

Looking back at the churches' response to school desegregation in the turbulent 1960 's and early 1970's, some pastors and elders later suggested that the church was unaware that long exposure of its youth to secular values they encountered in the public schools would lead to the abandonment of their religious traditions, which in turn would cause many of the social ills that would come to plague Perrine in the ensuing decades. Perrine's children, in attending public school, spent the majority of their waking hours in an environment far removed from the familiar church-based society they knew at home. Religious teaching and prayer were part and parcel of Perrine's way of life, but children attending public schools found little to encourage this form of expression. At the time of desegregation, public schools across America were operating in accordance with a narrower approach with regard to their guardianship of the religious freedom of its citizens. Society at large was making room for more diverse religious groups and schools were under pressure to restrict, rather than allow religious practices. One of the costs of integration was the denial of this important aspect of self expression on the part of 
Perrine's black children. Delores Alexander, now a pastor at a Pentecostal church in neighboring Goulds grew up in Perrine and was among the first class to attend a white high school the summer before she graduated from Mays High School in 1966. She gave voice to a widespread belief that eventually would be adopted by the Perrine community, that public schools were indoctrinating children with secular views. She said that churches did not realize this was happening until it was too late. "It was so subtle that we never expected it. And so when we wake up one morning and you realize that your kid has been going to a public school that has preached secular humanism. ... and they have been going for six to eight hours a day, five days a week. . ${ }^{50}$ The result, explained Mr. Finkley, was that young "people quit praying, quit going to church" and, he added, because "the devil got in them."

By the 1970's, Perrine had become a site of black male youth engaged in selling drugs and many females supported by welfare. Later, church leaders would accuse many of Perrrine's young people of adopting the "new" materialism and "get rich quick" values of white society and of becoming involved in drug dealing, thinking that this was a faster and better way of getting ahead than the avenues their parents had pursued. ${ }^{51}$ Some believed that girls in Perrine had a materialistic incentive to become pregnant, believing that if they got pregnant they could achieve a much desired independence from their parents because the new government social welfare programs provided a single mother with a free apartment and food stamps. The encounter many youth had with these secular values resulted in a generation of young girls raising another generation of children who would grow up unchurched. ${ }^{52}$ This resulted in a deepening generational rift. As young 
people stopped going to church, Perrine's continuity was threatened as transmission of cultural modes between the generations was disrupted.

Churches responded by becoming more inwardly focused. They concentrated on saving souls, intensifying their participation in prayer groups, and by exhorting against sinners, but these practices only seemed irrelevant to youth who lived most of their lives in a world devoid of a church-based life. Theological differences between churches became more pronounced as churches withdrew into themselves. Differences between churches resulted in isolation, and to a breakdown of the cohesion of the community. ${ }^{53}$ For Perrine, this translated into a loss of civic social capital.

\section{West Perrine's Growing Population Challenges its Cohesion}

Another challenge to the cohesion of the community was its growing population. It was difficult to integrate the new population into the existing one because the newcomers did not share the values of the existing population, such as a strong work ethic, appreciation of community service, and pride in ownership. Many newcomers lived in new rental properties made available as slum landlords, both white and black, built apartment buildings and cheap duplexes, and bought and rented out the old oneroom shacks that had served as quarters for farm workers, some of them dating to the 1920 's. These newcomers, many of whom were relocating from other black slum areas closer to the city, were several steps ahead of those in West Perrine in their response to social changes. ${ }^{54}$ Many of them had already stopped going to church. Rental housing encouraged transience. The pride the community once had in building and owning "good 
solid homes" and in making sure the community was physically cared for was eroding. Many of the older generation of community leaders who took care of looking after West Perrine's physical needs were passing on.

Ethnic diversity further complicated Perrine's community cohesion. Of Perrine's original black settlers who had arrived around the turn of the twentieth century, when Perrine was beginning to form as an agricultural village, most were Bahamian, and the others were from Northern Florida and Georgia. Immigration and migration continued into Perrine from these areas throughout the first third of the century. However, large numbers of new American blacks, from all over the South, began to arrive in Perrine after WWII. Others began to trickle in from the city of Miami, some having been displaced by the dismemberment of Colored Town, Miami's original black neighborhood. In the late 1970 's and 80 's there was a large influx into Perrine of black immigrants largely from Jamaica, although a few were from other West Indian Islands, South America, Africa, and Asia. ${ }^{55}$ In the late 1980's and early 1990's newcomers from this group would establish two Protestant Jamaican churches, a Muslim mosque, and a Hindu Temple, but these institutions would remain separated from the other thirty some odd churches, all Protestant that made up the one square mile area of Perrine, now an all black community. ${ }^{56}$

The lack of cohesion in Perrine due to the difficulty in absorbing new populations, each of which came to Perrine with different values, histories and senses of community, meant a weakening of the bonds of trust and social connectedness that had existed among the dense social networks that had existed in Perrine throughout its history. ${ }^{57}$ As a result, this period saw a steep decline in civic social capital for the Perrine community. 


\section{West Perrine is Ravaged by Urban Decay}

By the 1980 's West Perrine was one of the most crime-infested areas in Dade County. ${ }^{58}$ The original residents of West Perrine, those who had bought their property, built their homes, formed their churches and schools, and raised their families, watched the community they had built being destroyed from the inside. Slum landlords, both white and black, built apartment buildings and cheap duplexes, and more housing projects went up. As happened in other black urban areas throughout the country, abandoned homes were turned into crack houses. Drug lords ruled the streets. Teenage gangs terrorized the town with shootings, assaults, car thefts, armed robberies and drug dealing. Residents were afraid to leave their homes and police were afraid to go into the neighborhood. In the early 1980 's race riots had erupted in black neighborhoods elsewhere in Miami, and there was concern that West Perrine could be next.

West Perrine, ${ }^{59}$ a community that encompassed only sixteen square blocks, had become a dangerous neighborhood. Yet, it remained rich in churches, with almost forty in all. ${ }^{60}$ There were two Methodist and two Baptist historic churches that were formed by the 1920s. There were two additional Baptist Churches, including Sweet Home and St. Peters, both of which had begun as breakaway churches over disputes. The other churches were small independent churches, Pentecostal, Apostolic, or Holiness. ${ }^{61}$ Many had memberships of no more than 40 or 50 , and the membership in some of these churches consisted primarily of little more than an extended family. Some were established by pastors outside of Perrine who had a calling to locate in Perrine. ${ }^{62}$ Breakaway churches, also referred to as "bastard churches," were common and reflected 
schisms in the community, some of which occurred over doctrinal disputes and others as a result of personality clashes or power struggles or because of the unacceptable moral behavior of a pastor. Orientations were often reflected in their names, such as Holy Faith Tabernacle Deliverance Center of Apostolic Faith, Christian Converts for Christ Ministries, Triumph Church and Kingdom of God in Christ, Evangelist Mission Church of God in Christ, Community Church of Christ Written in Heaven and Pentecostal Church of Our Lord and Savior Jesus Christ. But these churches were ill-equipped to handle the destructive issues facing the West Perrine community at large, such as drug abuse, teenage pregnancy, single family homes, poverty, and school drop outs. 
${ }^{1}$ Taylor, Villages, 60; Bishop Ingraham interview, April, 2002. LVII (1997).

${ }^{2}$ Gary R. Mormino, "Midas Returns: Miami Goes to War, 1941-1945," Tequesta

${ }^{3}$ Racial violence erupted in 1911,1915 , and 1920 when blacks attempted to cross the "color line," so called by several Miami newspapers. (Mohl, "Whitening," 322; George, "Colored Town," 441-442).

${ }^{4}$ By 1920 Colored Town was already becoming overpopulated, with inadequate housing and waste management leading to slum conditions. (White) city planners had decided by the early 30's that the best way to deal with Colored Town's slum conditions would be to relocate blacks from downtown Miami to outlying areas. Moving blacks out of Colored Town would also allow them to enlarge the downtown business district. In 1937, Liberty Square (later to become Liberty City), was completed with New Deal federal housing funds. (Other plans for "Negro Resettlement" that were never implemented called for relocation of blacks to outlying agricultural areas. One such area was west of Perrine.) [Mohl, "Whitening", 321-323; Brown and Hudson, "Henry Flagler," 67-69].

${ }^{5}$ Mohl, "Whitening," 326.

${ }^{6}$ Ibid., 328.

${ }^{7}$ Ibid., 330-332.

${ }^{8}$ This letter was cited above. (Model Land Company Records, Box 93, Folder 1673, File 2109, Letter from Pepper and Coffrin to Mr. Carl W. Hawkins, Vice-Pres. of Perrine Grant Land Company, Feb. 9, 1943).

${ }^{9}$ Model Land Company Records, Box 108, Folder 1868, Special File 2,326, Letter from John A. Tackaberry, to Mr. Frank J. Pepper of Pepper and Coffrin, Inc., November 13, 1952.

${ }^{10}$ The HOLC appraisal system was used by private financial institutions and the Federal Housing Administration in evaluating mortgage and loan applicants. Very few blacks in Miami were able to obtain FHA mortgages because the properties they could buy were in high risk areas. The Veterans Administration would use the same appraisal system in making its determinations. Disregarding the 1946 ruling, the 1947 edition of the FHA's Underwriting Manual opposed neighborhood "invasion by incompatible racial and social groups" and advocated residential segregation as a means of maintaining community stability. (Mohl, "Whitening," 327). 
${ }^{11}$ Dunn, Black Miami, 208.

${ }^{12}$ Mohl, "Whitening."

${ }^{13}$ Miami Daily News, "Negro Housing Development Ok'd," August 23, 1949.

${ }^{14}$ Charles B. Forbes, "Richmond Heights Challenge to Negro Community Builders," Miami Sunday News, 20 May, 1951.

${ }^{15}$ Ibid.

${ }^{16}$ John T. Bills, the Miami Herald's Real Estate Editor wrote in an article about Martin and Richmond Heights, that Martin "undertook the development after consultation with a committee of Negro leaders. And he still relies on the committee." Other civic leaders were listed as Associate Judge L. E. Thomas of Miami municipal court, Charles Ratcliffe, employee of the Veterans Administration hospital, Coral Gables and David Douglas, Miami representative of the Atlanta Life Insurance Co. (John T. Bills, "Richmond Heights. . Shangri-la For Negroes: Former Pilot is Developer," Miami Herald, section G. 20, May. 1951)

${ }^{17}$ Raymond Mohl, "Elizabeth Virrick and the "Concrete Monsters:" Housing Reform in Postwar Miami, Tequesta (2001),12-13.

${ }^{18}$ The Racial Relations Service was headed by Frank S. Horne, a member of FDR's "Black Cabinet," (and opera singer Lena Horne's uncle). Although Horne was committed to integrated housing, post-war political realities led to his supporting segregated housing in order to obtain much needed housing. Horne was involved in obtaining privately financed housing for blacks in Miami. (Mohl, "Whitening," 338339).

19“"Frank C. Martin Killed In Crash,” Miami Daily News, 23 May, 1951.

${ }^{20}$ Model Land Company Records, Box 75, Folder 108, File 1868, Letter from Frank J, Pepper to Carl W. Hawkins, May 28, 1951.

${ }^{21}$ John T. Bills, "Martin Death Won't Stop Housing Project," Miami Herald, section G, 27 May, 1951.

22 "Plan 3,600 Homes in Richmond Heights," Miami Herald, 9 January, 1955.

${ }^{23}$ In 1955, developer Davidson, in stating his plans for building more homes in the Richmond Heights area, still spoke in terms of segregated housing: "Our objective is a self-contained community for minority groups," in accord with "the suggestion expressed by President Eisenhower and various national organizations that the minority housing 
program be expedited." (Ben Schneider, "Big Housing Project Seen for Perrine," MiamiDaily News, 1 January, 1955.

${ }^{24}$ Bills, Miami Herald, 27 May, 1951.

${ }^{25}$ Two families in this case study, Fannie Mae and Sinclair Williams and John Bruton, bought in Perrine's project. Each family made $\$ 25$ down-payments in 1950 for CBS construction modern three bedroom homes which they own to this day.

${ }^{26}$ Bishop and Mrs. Ingraham interview, January 2003.

${ }^{27}$ Dunn, Black Miami, 213; Perrine's civic leader and pastor, the Rev.Doc Coleman, became Dade County's first licenced black electrician. (Archie Finkley interview, February 2002).

${ }^{28}$ During WWII blacks from Perrine had worked on the Blimp Base at nearby Richmond Naval Air Station, which operated from 1942 until it was destroyed by a fire in 1945. (Fannie Mae and Sinclair Williams interview, March 2002; Bishop and Mrs. Ingraham interview, April 2002).

29 John Bruton, interview by the author, tape recording, Perrine, Fla., 27 Nov. 2001.

${ }^{30}$ Bishop and Mrs. Ingraham, April 2002.

${ }^{31}$ In an ironic twist, after this ruling, the bus drivers went on strike and management invited blacks to break the strike. Later, when the County purchased the bus company, the white drivers had not ended the strike and the County continued service with the black bus drivers. (Dunn, Black Miami, 214-215).

${ }^{32}$ Dunn, Black Miami, 172.

${ }^{33}$ Finkley interview, February 2002; Vester Jefferson, member of Mt. Sinai Baptist Church, Perrine, Delores Finkley, and Archie Finkley, interview by author, tape recording, Perrine, Florida, 25 March 2002.

${ }^{34}$ Delores Alexander interview, April 2002; Green interviews, March 2001 and October 2001.

${ }^{35}$ Mohl, South of the South, 4-5 on the historiography of the Civil Rights movement.

${ }^{36}$ Raboteau, A Fire in the Bones, 59. 
${ }^{37}$ Alejandro Portes and Alex Stepick, City on the Edge (Berkely: University of California Press, 1993), 178.

${ }^{38} \mathrm{CORE}$ 's nonviolent but confrontational tactics did not appeal to many local blacks. None of Miami's black clergymen participated in the early lunch-counter eat-ins, although they did not oppose them. (Mohl, South of the South, 55).

${ }^{39}$ In 1959, the Johns Committee, Florida's version of the McCarthy Commission, demanded that the Miami Chapter of the NAACP hand over its membership list. When NAACP president Father Gibson refused he and Rev. Graham were sentenced, jailed, and fined until 1963 when the Supreme Court overturned their conviction. (Dunn, Black Miami, 220).

${ }^{40}$ Most of the white advocates of racial justice in the postwar era were Jewish. Mt. Sinai Hospital on Miami Beach employed black physicians in 1952 and some Jewishowned hotels and restaurants on Miami Beach desegregated in the 1950s. But many mainstream Jewish organizations and politicians shied away from civil rights involvement out of fear of being labeled communists or anti-American. One notable exception was Jack Gordon of Miami Beach, who lost an election because of his politically unpopular support of school desegregation. Gordon later became a powerful state senator. (Mohl, South of the South, 26-27; Deborah Dash Moore, To the Golden Cities: Pursuing the American Jewish Dream in Miami and L.A., [Harvard University Press: Cambridge, 1994], 153-187).

${ }^{41}$ The black activist group involved in the negotiations was the Ministerial Alliance (headed by the Rev. Edward T. Graham). The bi-racial activist groups were the NAACP (represented by Father Theodore Gibson and Dr. George Simpson), CORE (represented by A.C. Moore and Dr. Brown) and the Dade County Community Relations Board. (Dunn, Black Miami, 217-218; Mohl, South of the South, 57-58.)

${ }^{42}$ Dunn, Black Miami, 176.

${ }^{43}$ Bishop and Mrs. Ingraham interview

${ }^{44}$ Bishop and Mrs. Ingraham interview

${ }^{45}$ See Dunn, Black Miami, 224-237 for a more complete history of the desegregation process of the Dade County public schools. Many approaches to desegregation were tried over the years, including court interventions, law suites, and plans such as various school pairings, clusters, busing, boundary changes and magnet programs. But because of segregated residential patterns, many of these efforts proved unsatisfactory for a variety of reasons. Some parents urged re-segregation because of the hardships their children were forced to endure, including the long hours on buses.

Parental involvement was also difficult to maintain when children were attending schools 
outside their neighborhoods. Schools tend to be less receptive to the particular needs of children outside of their neighborhoods. In 1983, one Perrine parent, Ruth Page, led an unsuccessful bi-racial group of parents that pushed for re-segregation. (Perrine's elementary school R.R. Moton had been desegregated since 1971). Another prominent parent from Perrine, Ethel Beckford, was eventually successful in relocating Perrine's elementary school children back to Perrine. A second elementary school in Perrine was named for her.

${ }^{46}$ Shirley Green interview, April 2002.

${ }^{47}$ Shirley Green interview, April 2002: Delores Alexander interview, April 2002.

${ }^{48}$ Shirley Green interview, April 2002.

${ }^{49}$ Ibid.

${ }^{50}$ Finkley and Alexander, 15 Feb. 2002.

${ }^{51}$ Archie Finkley, and Delores Alexander interviews, Feb. 2002.

${ }^{52}$ Ron Tookes interview, Dec. 2001

${ }^{53}$ John Bruton interview, Nov. 2001; Shirley Green, interview,March 2001 and Oct. 2001; Delores Alexander, interview April, 2002; Bishop and Mrs. Ingraham interview March 2002.

${ }^{54}$ Dolores Alexander (Vester Jefferson interview, March 2002); Ron Tookes interview; Dec. 2001; See Paul S. George and Thomas K. Petersen, "Liberty Square; 1933-1987 The Origins and Evolution of a Public Housing Project," Tequesta, XLVIII 1988 for an analysis of the deterioration of families and individuals living in a public housing project in Miami. This article tracks the occupations, employment history, family status and origins of tenants over a 40 year period. Although no such study was done in Perrine, similarities may be assumed.

${ }^{55}$ Raymond A. Mohl, "Black Immigrants: Bahamians in Early Twentieth-Century Miami," Florida Historical Quarterly, Vol. LXV, no. 3 (Jan. 1987), 434-450; Jerrell H. Shofner, "Florida and the Black Migration," Florida Historical Quarterly, Vol. LVII, no. 3 (Jan. 1979), 267-288.

${ }^{56}$ West Indians, for example were were noticeably absent from the NRT meeting described in the Prologue of this thesis. 
${ }^{57}$ Glenn Loury has written about the deterioration of cities during this period in "A Dynamic Theory of Racial Income Difference." Cited in Francis Fukuyama, The Great Disruption: Human Nature and the Reconstitution of Social Order, (New York: The Free Press, 1999), 19.

${ }^{58}$ Miami and Dade County merged on Nov. 13, 1997 to become Miami Dade County.

${ }^{59}$ From this point on, Perrine, whether referred to as Perrine or West Perrine will designate black Perrine.

${ }^{60}$ Hurricane Andrew destroyed many of West Perrine's churches in 1991.

${ }^{61}$ These are usually grouped together under one classification: "Sanctified Churches."

${ }^{62}$ Although it is usual for pastors to seek divine guidance in making decisions, especially about where to pastor, two pastors admitted to being led specifically to Perrine. They were Rev. Walden of Perrine New Testament Church of God (Jamaican) and Bishop Watson of North Miami Beach, the later who related that he was shown a specific church opposite a school, owned by a specific person in a dream that he was directed to purchase and to pastor. He related to the author how he drove South looking for this church and found it in Perrine. Bishop Watson is the third president of the West Perrine Christian Association. 


\section{Reactivation of Perrine's Civic Social Capital: 1980-2002}

\section{Richmond Heights Comes to the Aid of Perrine}

Its power base having been eroded, Perrine was now at the mercy of a range of individuals, from slum landlords to drug lords, each seeking individual profit at the expense of the community. Into this power vacuum stepped church and business leaders from Richmond Heights, who offered help to Perrine.

True to Frank C. Martin's vision, Richmond Heights had attracted many of Miami's black middle class elite who were drawn by the stability and comforts of this community. By the late 1970s Richmond Heights had become a locus for black political power, based as it was traditionally in the black church. The pastors, serving a more educated group, were themselves more sophisticated and educated than those in Perrine. By way of associations with other churches, they had access to new developments in church organization and outlook. Some of Richmond Heights' churches devised new strategies to deal with the social ills that plagued the black community. One leading pastor, Rev. Ferguson of Second Baptist Church, preached social responsibility, social action and unity through which blacks could achieve political power. He encouraged churchgoers to provide social services to neighboring black communities and especially to youth. ${ }^{1}$ This commitment to community and youth throughout the wider black society was consistent with values held by blacks in South Dade over the course of the century. The efforts of tomato farmers Arthur and Polly Mays who bussed black children from the far reaches of South Dade to and from school in the 1930's, comes to mind in this regard. 
By the early 1980s, a group of black community leaders from Richmond Heights, was firmly established in West Perrine. They had transplanted their successful social service model to Perrine. The Jaycees, the Masons, and the Community Action Agency were used to deliver social services to the community, but the most influential social action group was the Richmond/Perrine Optimist Club. It was made up of business people, school principles, teachers, and pastors from Richmond Heights, and was chaired by developer Ed Hanna, who was working to improve real estate values in Perrine by replacing slum housing with single family homes and by helping residents, many of whom lived in projects, to qualify for mortgages so they could move into those homes. ${ }^{2}$ His partner Dennis Moss, who would become the area's first black county commissioner in 1993, focused on crime prevention and youth. He ran a last resort school for teenagers expelled from the Dade County Schools and a crime prevention program. (He is still CEO of the organization at the time of this writing.) In 1983 the Rev.Walter Richardson joined this group when he became pastor of Sweet Home Missionary Baptist Church in Perrine.

The immediate goal of this group of black community leaders from Richmond Heights was to restore West Perrine as a viable black community; their long term vision was the empowerment of the community as a political force. This group formulated the "Seventeen-Point Plan" a schema to implement the rehabilitation of West Perrine. The issues addressed in the Seventeen -Point Plan were very similar to those addressed by the Negro Council thirty years earlier: lighting, housing, schools, police, crime, and garbage pick up. They centered their efforts on the replacement of substandard housing, crack 
houses, night clubs, package stores and rental properties with single family homes. Eradication of the local street drug trade would soon be added to their list.

\section{Rev. Walter Richardson As Spokesman for the Richmond Heights Group}

A protege of Rev. Ferguson of Second Baptist of Richmond Heights, where he had served as youth minister, Rev. Richardson brought a new type of church vision to Perrine, one dedicated to social justice and action. Brought up in a housing project and third in his family's line of Pentecostal pastors, Rev. Richardson set upward mobility as a personal goal. He had left the Pentecostal church for the Baptist Church, much to the dismay of his family, in order to gain a wider exposure for what he came to believe was his mission, that of social action and justice. When he took the position at Sweet Home in 1983, he was an accomplished musician, had attended seminary, had a well-paying job as an executive at Sears and Roebuck and lived comfortably in Richmond Heights with his family. His education would eventually include two master's degrees and a Ph.D.

A charismatic preacher, Rev. Richardson became the spokesman for the Richmond Heights group of community leaders. He undertook the task of mobilizing community support for the Seventeen Point Plan. He knew that to bring about any tangible change, he had to change the attitudes of a whole community of people who seemed mired in what he called the "generational curse" of poverty and hopelessness. Rev. Richardson used the pulpit at Sweet Home as a forum from which to preach social change as the way towards empowerment, personal and social. He tried to reorient the attitudes of the community to the goals of upward mobility and inclusion into the larger 
society, that is, Dade County and beyond. He realized that for Hanna's redevelopment plan to work, the community had to be convinced that it made more sense to buy a home than to rent one (for example, given that mortgage payments were commonly less than rent). Rev. Richardson would preach the value of home ownership to his congregation: "If you drive a car off the lot it's already lost value. It's now a used car but it makes you look good temporarily. But if you buy real estate, or if you buy a house, normally it increases a time goes on. So why would you want to spend all your money on something that's going to lose value?" He would tell them, "Why do you spend all your money on something you don't have, to buy things that you don't need, to impress folk that you don't like?"3

Although Rev. Richardson attracted some members from Perrine, his message appealed more to the more upwardly-mobile and educated black middle class who resided elsewhere, who responded to his dynamic teaching and exegesis, because he spoke about their struggles, hopes and ambitions. His congregation was an educated group who regularly read the newspaper and watched the news on television. Many were professionals (teachers, nurses, doctors, lawyers and government administrators) who lived in Richmond Heights. They looked forward to his weekly sermons which integrated current events and Biblical teachings. He inspired them with his vision of social responsibility towards their less fortunate brethren. Already in the 1980 s he was developing a highly public profile, becoming involved in causes throughout Dade County, such as hunger strikes to protest Haitians detained by the federal government as illegal immigrants. 


\section{Perrine's Fractured Community an Impediment to Civic Social Capital}

Rev. Richardson was less successful at this time in reaching the fractured segments of the West Perrine community, particularly given the significant class difference between the Perrine population and the Richmond Heights middle class group, as reflected in education levels, standards of living, types of jobs, and relative unemployment numbers. Rev. Richardson complained that "there are people who don't like Sweet Home because we keep our yard clean. And we paint our Church. And we have nice cars in our parking lot on Sundays. There are people who say, I can't go to that church, that's upper crust. And here we're trying to empower the community and say listen, what we are is what you can be."

Rev. Richardson was equally unsuccessful in attracting the Perrine pastors to join his cause. The large number of churches in West Perrine bespoke of disagreements between them. Seemingly irreconcilable theological and social divides as well as power struggles between pastors prevented cohesion between the churches. One such divide was the classic dispute between the Pentecostals and the Baptists. Pentecostal church leader Shirley Green gave her version of this dispute: "If you have a Pentecostal and you have a Baptist, if you just listen to their sermon, you will say, oh well, it sounds fine. They are reading the same Bible, they are preaching the same sermon. However, as far as living it, the Pentecostal will say, I have to live everything that is in the Bible. Whereas the Baptist would say you know, if I want to have a little woman on the side, that'll be okay. And you know, if I go to night clubs and really do it up one night or so 
that'll be okay....We have some Baptist ministers around here who have like five or six kids out of wedlock. ${ }^{5}$

Other disputes between churches centered on theological differences between Apostolics and others as to whether Christ should be worshiped as a unity as Apostolics contend, or a trinity. Again, Green comments: "I mean, they're (Apostolics) just off the wall. Now, no other religion, no other Pentecostal religion, or Protestant religion has a problem with them. But they have a problem with all of us. So we just say, okay, when you get to Heaven, you will just be surprised that we are there. Because they believe in the Bible, you know, they believe in everything that everybody else believes in but they just have this one little thing that just rubs them the wrong way. Oh, they just go off. ${ }^{6}$ Still other disputes were over the purpose of the church, some saying the purpose of the church is to "save souls" and not political activism.

Many of Perrine's older community leaders felt that the Richmond Heights group of social activists devalued their input. They felt excluded from the new political structure. "See, what happened now, all the old people, like me, now when they got the organizations together, the secretary, president, vice, and all that, they said they didn't want nobody in there under 45 years old. .. They wanted new blood. This is what they wanted.... And so all of these old people, were the backbone and done broke the ground, they had to set aside, cause they had a new thing going."7

Archie Finkley was one of the older generation of leaders who came to West Perrine in 1950, when several years of drought had forced him to sell his farm in Sewannee, Florida. He built three houses by himself and brought his relatives down to live in Perrine. He did not think Hanna's building practices encouraged empowerment 
but instead promoted the more secular influences of materialism which encourage buying on credit and wanting more than you can afford. "Negroes could have bought land and if you own a lot, you could build your house and ten years down and you own it. But, I don't know too many done that in Perrine... Everybody else just signed that dotted line (on the mortgage). I built two in twelve." 8 Furthermore, Finkley was critical of the homes Hanna built saying that they lack individuality and so don't contribute to Perrine's beauty: "See houses like that, you need different styles and things. You can beautify the community, too. Then what happened, we ain't never plan a community. ${ }^{9}$

\section{New Zone of Conflict is Identified: The Mustering of Civic Social Capital}

By 1986 Rev. Richardson realized that the community's most immediate threat came from within it and that unless the drug culture could be eradicated, the redevelopment of Perrine would come to naught. Not to be discouraged by the different factions in the community, and knowing that he would not be able to fight the drug dealers alone, Rev. Richardson attempted to build church solidarity by marching through the streets of Perrine on Saturdays and on Sundays after church, with as many supporters he could assemble. Richardson described the effort as a "compassionate confrontation" to show drug dealers that there is an alternative lifestyle available, but that if they were not interested in adopting it, the community would not allow their behavior to continue. Richardson described the marches: [We walk] "away down the streets, and we sing and we pray and we stop in front of crack houses and all that." 10 His efforts drew some 
support from the community, but the new power wielders, the drug dealers, were not put off.

Although Rev. Richardson and the Richmond Heights group had tried to mobilize the community against Perrine's drug dealers, it took a key event, the murder of a prominent businessman from West Perrine before the disparate factions of Perrine's community would join forces. The murder served to identify in unequivocal terms a common enemy, to delineate the zone of conflict on which the new battle would take place, and to forge new networks, unified now by a more integrated Christian belief system. The formation of these new ties and the subsequent political restructuring of the community led to the generation of civic social capital.

It was a horrifying event, involving a series of shootings over a two day period in May 1989 that culminated in the murder of black businessman, Lee Arthur Lawrence, that convinced Perrine's churches that their community was in trouble. Lee Arthur Lawrence had been marching with Rev. Richardson's group over the past few years, but had become impatient with the lack of progress being made to rid the community of the drug lords. He decided to take matters into his own hands, and began calling the police in repeated efforts to get the drug dealers off his property. The murder, in which Lawrence was shot 47 times by a drug gang member, shocked those who knew Lawrence and delivered a wake up call to many of the older members of Perrine's community, those who had retreated into their small church circles and closed their eyes to how far their community had deteriorated.

In an almost immediate response to the murder, the Perrine community formed the West Perrine Christian Association, a coalition of ministers, with Richardson as its 
president. In one fell swoop, Perrine's churches put aside their differences and came together in common cause, expressing in this gesture, a commitment toward the rebuilding and reclaiming of Perrine as their community. Bishop Ingraham of the Holiness church, Community Church of Christ Written in Heaven, was one of the first members of the Christian Association. He said that Lawrence's murder inspired him to combat the social ills that led to the tragedy. "When the ministers got out and said we have to form something, we got to invite all the churches, we all. And then we got together to form the Christian Association. Named it Christian Association. That's a bill we signed it fighting for, try to better our community. And which we made a promise to the community at his burial that this would not be him alone, but it would be us from here on in. We would take the fight and we would take the ball. We would run with it. So that's when my involvement came in the community." "This new coalition which included many of Perrine's churches and the spokesman for the Richmond Heights group reflected a redistribution of the power arrangement in Perrine.

Bishop Ingraham described how out of touch he had been in attending to communal affairs. He had only began to think of the drug culture as a threat to the community a few weeks before the murder when he was invited to attend a community meeting at Rev. Ferguson's church in Richmond Heights, Second Baptist. "I heard one policeman which started me, the police I can't remember his name. . I heard the chief say I'm sorry what they're doing to you. . . He said, I'm sorry that I apologize for the threats you're getting on your life and I apologize for the way you have to take a stand by yourself. And I'm listening to him. . . Well I don't even know they're doing it. I'm living right here. I don't know they're doing anything. Because I was not involved. ${ }^{12}$ 
Bishop Ingraham acknowledged the lack of connection between members of the community. How different the community had become since the days when his dad and others took care of communal affairs.... "That's his [Lee Arthur Lawrence's] home over there so I know him since he was a little boy. I knew he grew up so we never lost communication with each other. But we never had any dealing with each other because I was in a Pentecostal church and they were wherever they were. Our dealings, our paths just didn't cross. But I never heard that he was in this trouble. Until that day. So we come outside, and I was still trying to get a little more understanding. I said, now son, I was listening to what police chief or mayor or what he was. . I said now, you had better be careful. He said, 'Well Ingraham, I'll tell you what I am going to do.' He said, 'I'm going to do what I've got to do.",13

With the newly formed association of ministers as part of the new political structure, more of the community participated in Richardson's marches through the streets of Perrine, hoping to rout the drug dealers from its streets. The generation of civic social capital by this new association led to the accumulation of more civic social capital as outsiders were enlisted to Perrine's new cause. The weekly marches attracted media attention and bus loads of church members, white and black, from areas all over Miami, and from as far away as Key Biscayne, began arriving to lend their support. As more and more people began marching, the police, who had previously been afraid to enter the area, began dispatching forty to fifty officers to West Perrine every weekend.

Now the West Perrine community supported and authorized the Richmond Heights group in its clean-up efforts. Package houses were shut down. Drug dealers were subdued. Citizens felt safer in walking the streets. The new police presence, which 
Richardson had solicited, sent a message that the community no longer tolerated crime. Hanna's group, drawing more support and appreciation from the community, continued demolishing crack houses, building single family homes for which he offered affordable mortgages, and putting pressure on slum landlords by citing code violations to authorities. Civic social capital increased as citizens felt safer and their neighborhood began to feel more stable.

The Lawrence murder, a pivotal event in West Perrine's history, was made into an instrument of civic social capital, as the "Incorporation Story" forty years earlier had been. The murder became an important part of the history of Perrine, bespeaking the importance of community values to Perrine and the pride its citizens had in participating in communal affairs. It was remembered at important events like funerals, where in black communities histories are often told, and at memorials, like the annual Lee Arthur Lawrence the community of West Perrine holds on May 20, the anniversary of the day Lawrence was shot. Bishop Ingraham recounted one recent memorial, where as chaplain of the West Perrine Christian Association he spoke of the sacrifice Lee Arthur had made in bringing the community back together again: "We just had the memorial a few months ago and I had to speak at the memorial. And I had to reiterate. I had to say it. I'm very sorry to him and anybody else I was not involved. I was in my church and I was in my saving groups and I was not involved in the drug fighting. But this man was a business man. And he didn't want this kind of business around his property where his business is and therefore he stood out like a sore thumb because he didn't want them around them. And the dealers got against him for this, for the stand he was taking." 
The Lee Arthur Lawrence memorial is a symbolic event through which the Perrine community reaffirms its commitment to civic responsibility by honoring a man they believe died performing a heroic act. It is a quasi-religious event, commemorating the sacrifice Lawrence made for his community, including prayers, a retelling of the story, and a march through the streets of Perrine, led by the ministers of the West Perrine Christian Association. It begins at Ethel Beckford Elementary School, symbolic for the significance children and education holds for Perrine's community, and passes down the street (which since has been named for him) where Lawrence's business was and where he was murdered. Through this memorial the community relives the event that reunited their community, and reoriented their focus back to the civic goals they had long ago abandoned.

\section{A Second Political Restructuring Enables the Creation of Additional Civic Social Capital}

The Perrine community was able to attract outside groups and form coalitions and partnerships with them because of its extensive storehouse of civic social capital. One of the most important achievements for Perrine was when State Attorney Janet Reno lent her support and political weight to assist the community. Reno's involvement led to the formation of an important broad-based coalition, the Neighborhood Resource Team (NRT). The NRT linked government agencies, including the police department, with the Richmond Heights group, businesses, the West Perrine Christian Association, and through them, Perrine's individual churches and their congregants. 
As Mark Hoogle and Dietland Stolle have maintained, the generation of [civic] social capital "is dependent upon a sustained and synergistic interaction between civil society and government institutions. ${ }^{14}$ The NRT, because of its excellent design, but especially due to the exemplary guidance and direction of Ron Tookes, who was black, a police officer, and a local church member, was instrumental in bridging these two parts of society. Tookes was adept at managing and facilitating the flow of information across this network, which increased the levels of trust between Perrine's churches and the government.

Other important attainments for the community were the election of Dennis Moss to the Board of County Commissioners, a reduction in Perrine's crime rate, and a general improvement to the overall quality of life. Moss's election was a culminating achievement for the black community, marking inclusion into the larger political system, from which it had long been excluded.

The Neighborhood Resource Team

Richardson's marches, the formation of the Christian Association, and the increased media attention to Perrine attracted the attention of then Dade County State Attorney Janet Reno, who began attending the meetings of the West Perrine Christian Association. In a city already beset by riots, there was concern that West Perrine might be next in line. Reno was attracted to West Perrine because of its strong sense of community, reenforced by its well-defined geographic boundaries, ${ }^{15}$ its history of 
community involvement, and because it enjoyed a better relationship with police than did communities elsewhere in the county. ${ }^{16}$

As Reno began attending the West Perrine Christian Association meetings at Moton Elementary School, she sensed the abundant resources the Perrine community possessed. Reno already had strong relationships with many in the South Dade black community. She had been impressed by Perrine community leader Ethel Beckford, whom she called "the heart and soul of the community." Over the years, Beckford, whose own son was a police officer, had invited Janet Reno to speak about crime at her church and at community meetings held at Perrine's Moton Elementary School. According to Reno, Ethel Beckford cared deeply about the children of the community and "was not a lady to take no for an answer." 17 Reno had also established relationships with a number of black religious leaders from Richmond Heights, and they were at these meetings as well. Rev. Ferguson of Second Baptist in Richmond Heights, for instance, had worked on her political campaigns and had represented the black community in fighting for better education and campaigning for Affirmative Action. ${ }^{18}$ Rev. Walter Richardson was gaining exposure throughout Dade County as a successful black community activist, able to garner broad based community support to fight the drug gangs that were devastating his South Dade neighborhood. ${ }^{19}$ According to Rev.

Richardson, it was Janet Reno who initiated this collaboration between government and citizens when she approached several local pastors, including Rev. Ferguson and Rev. Richardson, to try to devise a plan to lower crime. ${ }^{20}$

As the State Attorney for Dade County, the prosecutorial arm of the state, Janet Reno knew that the traditional use of a police force to fight crime in lower-income areas 
was not effective because the underlying problems of health issues, education, housing, and low paying or lack of jobs, only perpetuated this cycle and because relations between the police and communities were usually poor. The "Team Police," approach, already in place in certain crime areas in the county, was supposed to improve relationships between police and community. The police were supposed to refer people with social problems, such as health, housing, and family issues, to an appropriate government agency, but their main emphasis remained law enforcement, and often social issues were lost in the bureaucracy. Reno realized that what was needed was a way to stitch together the valuable resources strong communities possess with those of the government. She saw that West Perrine possessed a wealth of civic social capital. ${ }^{21}$

Reno saw her job as bringing governmental agencies in line with the needs of the community and then devising a plan for the community to access these governmental resources. Sitting in on the West Perrine Christian Association's weekly meetings she listened to the pastors and other citizens share their frustrations over not being able to meet basic living requirements, hearing how the welfare programs are preventing families from being able to afford to live together, how they are encouraging further dismantling of the family by giving incentives for single teenage girls to qualify for housing by having babies, and many other examples of government policy working against itself. She listened as pastors complained that welfare programs were destroying the African American family unit, and that children were being raised without male role models and that the church, long the heart of the black community and an institution crucial to the existence of African Americans was being abandoned. Pastors felt that children growing up without the moral values and guidelines traditionally furnished by church and family 
easily fall prey to peer pressure and the life of crime. The pastors believed that only by putting religion back in black youths' lives would it be possible to eliminate crime. ${ }^{22}$ Aware that governmental policies were often at odds with citizens' needs, Reno had already begun to push for reform. Prior to her most recent involvement in Perrine, she had spent time in Modella and Goulds (two black enclaves South of Perrine) dealing with public housing issues there with Tom Peterson, a circuit court judge in the juvenile court system. Her office had sued the Public Housing Authority and received a consent decree to improve their management of public housing projects throughout the county in an effort to bring down crime rates. She was also working with the juvenile court system to address children's problems, especially in the area of domestic violence, which she viewed as the greatest contributing factor in the persistence of social pathologies through the generations, as a means of crime prevention. ${ }^{23}$

After attending many of the weekly meetings over a two year period at Moton, Janet Reno assembled the Neighborhood Resource Team (NRT), a multi-agency resource team which brought together HRS (the State Department of Health and Rehabilitative Services, which administered health, welfare, and juvenile delinquency programs in Dade County), the local Housing and Urban Development (HUD), the Miami-Dade Police Department (MDPD), and the School Board under one roof. The Team formally organized in April of 1992, in the Perrine Gardens Public Housing Project, a 220 unit apartment complex, built in the old Kerr Quarters (or Curry Corners, as locals referred to it), and which had deteriorated into one of Dade County's most dangerous projects, home of the much publicized Ninja Turtles Gang. The original NRT team consisted of four members: a police officer, a housing representative, a public health nurse, and a social 
worker from HRS. A fifth member, a social worker from the Miami-Dade Department of Youth and Family Services, joined the team in its second year. It began to function like a mini government, bringing representatives from the different agencies to systematically visit apartments together as a team to assess tenants' needs and to resolve their problems in a way that would not compromise the integrity of the family unit. Team members were experienced professionals, knowledgeable about the resources of their agencies, and with ready access to top officials.

Key to the success of the new agency would be the team coordinator, that individual who could organize the disparate elements of community and government. Reno appointed Ron Tookes, a black police officer and community leader from Coconut Grove whom she had known for more than thirty years, to head the NRT. Tookes became the intermediary between the police, the government agencies and the churches. He had a longtime commitment to community service, joining the police force in the late 1980 's because he believed that a closer relationship between the police and community would prevent race riots. After his appointment he moved to Richmond Heights, and joined the community building and clean up efforts of Richardson, Moss and Hanna. He eventually joined Rev. Richardson's church, Sweet Home Missionary Baptist Church.

Tookes was a good choice for the position for which he was selected.

He successful in bringing together the different factions of the Perrine community, in garnering support for Perrine's efforts in the outside community, and in connecting people in need with appropriate services to bring down the crime rate. More than anything else, Tookes was successful because he is a member of the larger governmental organization, he is black and he is religious and connected to the church. These 
characteristics allowed him to become something like a central electronic relay station, through which Perrine connected with the outside community. The connection facilitated the further accumulation of civic social capital and its deployment.

Reflecting on his own moral development, Tookes admitted that "the one thing that kept me straight as a youngster, and all of us straight as a youngster, was the fact that we feared God. And it wasn't so much that our parents had to see us do wrong, but we felt that God was looking." Tookes echoed the feelings of the ministers in the Christian Association that church guidance was essential to the delivery of social services when he said, "Government can not do it alone. Government needed community input. It needed input from the clergy, from the church." Tookes mused, "I know what really prompts my Afro-Americans to move in the right direction. And it's nothing that's generated by government influence. It's generated by religious influence."24

The NRT's success in lowering crime led to the creation of five more teams that in other, crime-ridden public housing projects and low income private apartment buildings in south Miami Dade. It also led to "The Family Preservation Program," which operated like a mobile NRT unit. The NRTs were set up in public housing projects and other low income housing complexes where the crime was considered the highest. As crime lowered in these areas, mobile units were dispatched, going street by street to individual residencies, in an attempt to become more comprehensive in its scope. Ron Tookes was made coordinator of the six NRTs and the Family Prevention program.

Tookes himself effectively described how he was able to access the stored civic social capital of Perrine's churches in order to bring down the crime rate. Tookes called his method "my own faith based initiative," that worked by "taking families to church, 
taking youngsters to church.... I'm finding that if a guy's on drugs, even though I'm very well connected with the Homeless Assistance Center [The HAC provides temporary housing for the homeless], down in Homestead Air force Base, and I get involved in that process, I find that sending him there without having him having some sort of faith based contact is no good. Because it's short term if he goes straight there without that. If I get Reverend Sumpter, or Bishop Watson or one of the clergy connected with that individual to give him the conversation that he needs, with the faith that he needs to hold out and to hang in there and we're here for you no matter what, that kind of stuff, without that, it's not working out. So about three or four years ago, I developed a system where if a guy comes in here or a family calls me and tells me that they have a family member who's on drugs, and he needs some help, I need to call Rev. Sumpter, or call one of the ministers and say listen, I need you to counsel this person. I'm about to send them down to the HAC but I need you to counsel them for me and talk to them about church and that sort of thing. . . I'd say it's better than methadone. . For the crack user it's one of the best things that we can do for them.,25

So effective was Tookes approach that he steered away from a traditional law enforcement approach. Sometimes, instead of arresting drug pushers, he tried to find them a job, but he did so on the condition that they go to church, any church: "Every person in the area is on crack or has a drug problem, or they got any kind of problem. All the ex-offenders, the heads of households, all the welfare mothers, all have our cards in their purse or in their pockets. If a guy's stopped on the street a lot of times I send mixed signals to the police department because a guy who's running from the police, they stop him. He's got my card on him. So they say, well, how you involved with Tookes. You 
know, well, he was trying to help me find a job. He wasn't able to get a job, so he's out doing whatever. So now that relationship has developed where the police officers now understand what's really happening here. They're liable to see me in the middle of a dope hole. Just sitting there talking to the guys. And I'm not arresting him, or trying to pat 'em down for drugs, any of that kind of stuff. But what I'm trying to do is to convince them to get off drugs. Stop selling drugs." 26

Tookes then tells them that he will be happy to help them but they need to come back to see him on a Monday but only if they have Sunday's church program. He tells them: “Sunday morning I want you in church with your mother. I don't care what church you go to, if you don't want to go to your mother's church, go to anybody's church. So then Monday morning for me to help you, you gotta come in here and tell me you went to church and bring the program"27.

Tookes also understands that one of the most serious problems in the black community is the absence of fathers in many homes, that without father figures, youth, particularly black youth, are at great risk. One of the foci of the NRT and Family Preservation program is to establish relationships with these young men (and to this end most of heads of the NRTs are male). The NRT heads counsel the male youth and mentor them. In many cases they are the authority figure these youth lack at home, using the power of the law as a threat, but also rewarding them for good behavior with fishing trips and football games, provided for by their partner organizations. ${ }^{28}$

Tookes' approach can be seen not simply as an attempt to give "religion" to those he sought to help, but to connect the church to the governmental organs of social services, to create and access a more powerful tool of social improvement. It is through 
such connections that civic social capital moves. In making such connections, Tookes went so far as to actually locate one of the government agencies he runs inside churches. The Family Preservation Center (the mobile NRT unit) holds two weekly meetings in churches to assist people in receiving proper health care and food, in finding jobs, and with school related issues.

Such a connection adds further power to the churches. Such meetings in churches brings the unchurched population back into the churches where ministers can reorient them spiritually. It also allows Miami-Dade's law enforcement agency to establish new connections with pastors and reenforces the already established network. The relationships established between pastors and the police allows pastors to connect people with material needs to an appropriate service provider. This becomes a cooperative effort, whereby churches become partners with the law enforcement arm of the government in eradicating crime.

After contributing to the power of the churches Tookes then accesses that power by using them to argue on his behalf to the county commission and to back him up in his conflicts with his department. In fact, Tookes refers to the pastors of the West Perrine Christian Association as his "board of directors." The Association deploys civic social capital by using their influence to get Tookes what he needs at City Hall, which comes back to benefit them. "I consider the Christian Association as my board of directors.... Wherever you set up shop, we really would love to have the clergy being our spokesmechanism. In other words, they're the ones that we can basically become cohesive with and they can see our needs. And one of the good things about working with the clergy and working with the ministers is that they don't have the restrictions of being able to, 
where they can't go down and talk to the Commissioners. And they can't do all the things that, a lot of things I can't do. ${ }^{29}$

The NRT team concept extended beyond government agencies to include private organizations such as churches, social clubs, other non-profit organizations and businesses. The NRT became a clearinghouse and referral service for connecting persons in need with the persons or agencies that could help them. Part of Tookes' job was establishing relationships with these different organizations, in order to form a network for his support system. He became adept at going into the wider white community to access their resources for his programs. He explained: "It's important for us to continue to educate the people we call the "haves," meaning the east side of U.S. 1, the Palmetto Bay folk, the Pinecrest folk to let them know how much I need them as a partner in order to be able to help ease the economic crises we're having on this side. There's very little that I ask of groups east of the highway, meaning those that have money, will they turn us down: The Rotary Club, The Perrine Cutler Ridge Counsel, the Kiwanis Club, the First Baptist Church of Perrine." ${ }^{30}$ Through his partnering efforts, Tookes received Thanksgiving baskets and toys for Christmas from these organizations. He got a fishing store to take 100 of his kids on an annual fishing trip, and the University of Miami to contribute football tickets for his "Join a Team and not a Gang" program. ${ }^{31}$

Bringing white institutions into the NRT coalition increased Perrine's civic social capital. By enlisting private individuals and institutions outside of Perrine to help those less fortunate within Perrine, Tookes established valuable ties between the "haves" and "have nots" based on shared principles much in keeping with an older tradition of American political culture. Tocqueville (along with America's founding fathers) had 
been insistent on the importance of "public virtues" to the proper functioning of civil society. In his "Memoir on Pauperism" written in 1835 after visiting England, Tocqueville argued that private charity was far less perilous to society than public charity because it was given "secretly and temporarily" and therefore less humiliating and degrading to the recipient than public charity. Private charity, he said, established a "moral tie between the giver and receiver", connecting the "giver in the fate of the one whose poverty he has undertaken to alleviate" ${ }^{\text {"32 }}$ Tookes, by cultivating a sense of civic responsibility in the "haves" towards the "have nots" helped to create a set of shared values between these two disparate groups. Shared values and cooperation resulted in increased levels of trust in these populations. Additionally, by integrating Perrine's goals into those of the wider community, Tookes helped to broaden the focus of each groups' collective life beyond their individual concerns. All these efforts enabled the generation of civic social capital.

The success of the NRT approach, particularly in the hands of Tookes, demonstrates how civic social capital can increase in value, i.e., purchasing power, when the storehouse of such capital (here, the churches and church based groups) are connected with other wells of power in the community in a direct and efficient way. Furthermore, each success (i.e., deployment of power) leads to further power.

Perrine's Political Power Base Expands in the Aftermath of Hurricane Andrew

Following the establishment of the NRT, two further events led to an increase of civic social capital in Perrine. On August 24, 1992, Hurricane Andrew, one of the most 
devastating Hurricanes ever to strike the United States, passed over South Florida. West Perrine was in the heart of the area most severely damaged by Andrew. Ironically, this proved a blessing for West Perrine because of the abundant resources which poured into the town in the Hurricane's aftermath.

One of these resources was an offer by the Miami Chapter of the American Institute of Architects (M/AIA) to help West Perrine design a plan, or a "Charrette," for a new town that would better serve its neighborhood, focusing attention on development rather than replacement. ${ }^{33}$ On August 31, a week after Andrew, as people and organizations locally and nationally were mobilizing to bring relief to devastated areas, the M/AIA decided to pick one community on which to focus its assistance. It selected West Perrine from among the many communities between Richmond Heights and Homestead that were hardest hit, giving as its reason, West Perrine's "strong, established leadership and community." ${ }^{34}$ Once again, Perrine's storehouse of civic social capital had succeeded in attracting additional civic social capital.

The M/AIA's involvement broadened the network of collaborative effort already in place. Between October and November 1992, when the plan was completed, members from the M/AIA met with Ed Hanna of the West Perrine CDC, several architecture foundations and associations, the West Perrine Christian Association, and a host of county political leaders, county department officials, and institutions in the private sector in a series of meetings. ${ }^{35}$ The Charrette, which was finalized in an intensive three-day session ending on November 15 , included plans for the final dismantling of West Perrine's historic Homestead Avenue, once its cultural center, to make way for commercial development and public facilities, including health and educational facilities, 
a vocational training center, housing and rehabilitation center, and the location of a major State of Florida agency.

The M/AIA understood the importance of community to urban revitalization. One of the significant features of the Charrette, was the solicitation of community input in the planning process. The West Perrine Christian Association's list of concerns were well articulated at these meetings, having been hashed out recently during its weekly meetings with Janet Reno. ${ }^{36}$ In an effort to preserve and enhance West Perrine's feeling of community (in other words, to help increase Perrine's stock of civic social capital), the M/AIA even enlisted community historian Ethel Beckford, who presented West Perrine's history to the group on November $13 .{ }^{37}$ Perrine's citizens made it clear that they wished to preserve the identity of their community. The Charrette addressed this concern, by designing "gateways," which defined West Perrine's limits, and "gate-way connections," points, along US 1, where Perrine's citizens could access neighboring areas enabling its residents to access educational, employment, and economic resources. ${ }^{38}$

The second important event that increased Perrine's political power, was the election of Dennis Moss as County Commissioner in April, 1993, following the tabulation of the 1990 Federal Census that resulted in a redistricting of Dade County. The new District 9 included the black corridor, mostly on the west side of Highway US 1, extending from Howard to Florida City. One of Moss's first accomplishments, and a testament to the impressive stores of civic social capital he brought to the County by his election, was the appropriation of $\$ 73$ million from FEMA on September 7, 1993 for rebuilding his devastated district. After the Hurricane, Moss had worked on several recovery efforts, including the aforementioned M/AIA Charrette, and the "South Dade 
Neighborhood Development Concept Plans" which he had sponsored. FEMA adopted the later plan, which the Commission renamed the "Moss Plan," and it was instituted as a comprehensive schema to revitalize some of the long-neglected communities of south Dade County. The Moss Plan involved business expansion and development, street paving and road improvements, affordable housing, community centers/recreation facilities, community gateway signs, redevelopment and expansion of parks, beautification projects, crime prevention, and home-buyer's counseling.

The decision to run Dennis Moss for commissioner was made by Hanna, Richardson, Tookes and Moss of the Richmond Heights group of community leaders. ${ }^{39}$ Moss had been running Perrine's Crime Prevention Center, (a last resort school for delinquent children and a tutoring program). The choice was a good one. Moss won easily. He continued as CEO of the Crime Prevention Center and is very much loved and respected by his constituents, being re-elected for three additional terms at the time of this writing. Moss's election solidified the power base of West Perrine, and especially of the Richmond Heights group of community leaders.

These events, including the formation of ever larger networks, particularly the NRT, and the election of Dennis Moss to the Dade County Board of Commissioners led to a second political restructuring of West Perrine. As Lindsay Paterson has suggested, shifting power relations contribute to the creation of new bonds of [civic] social capital. ${ }^{40}$ A change in power arrangements is evidenced by Rev. Richardson being ousted from his presidency of the West Perrine Christian Association. One of the reasons Rev.

Richardson was not re-elected to the organization he had founded centered around his selection (along with Sister Jeanne O'Laughlin, president of Barry University) to co-chair 
the "We Will Rebuild Religious Committee," in the aftermath of the Hurricane. This committee oversaw the distribution of a million dollars to rebuild three hundred religious institutions between Howard and Leisure City in South Dade. Some of the pastors in the Association felt slighted because Richardson had not selected their churches for participation in this program. ${ }^{41}$

Rev. Richardson was replaced by Rev. Joseph Sumpter of St. Peter's Missionary Baptist Church, who was succeeded in turn by Bishop Simeon Watson of the Pentecostal Church of Our Lord and Savior Jesus Christ. Now, the two main groups running Perrine were the original Richmond Heights group (including Hanna, Richardson, Tookes, Moss) and the West Perrine Christian Association (the active members were made up of churches with memberships primarily from West Perrine. Rev. Richardson retained his membership in the Association, but became less active). The division of political power now reflected a similar socio-economic dichotomy evident in the early 1980 's, with the Christian Association representing the lower economic strata. Ron Tookes and Commissioner Dennis Moss, influential members of the Richmond Heights group became free-flowing agents, moving back and forth between these two groups, facilitating civic social capital formation by their access to county-wide power and by disseminating and regulating information.

\section{How Information Contributes to the Generation of Civic Social Capital}

This chapter will demonstrate how information has been used in Perrine, through the institution of the West Perrine Christian Association, to generate civic social capital. 
Information has been used by Perrine's churches to access resources, to learn new ways to address problems, and to set civic goals. The later involves using information to shape collective understandings. This section analyses the flow of information in and out of the West Perrine Christian Association and through Perrine's network of power relations. In other words, it describes the effective functioning of a "grass-roots" system.

The West Perrine Christian Association, as a confederation of black churches, has been particularly suited to process information because of two of the traditional functions the black church has assumed: Black churches collect information and they help to connect members with needs to appropriate resources. Shirley Green comments on the important role the Association plays in the community, stressing the importance of addressing both spiritual and material needs of the congregants: "If they [Pastors in the West Perrine Christian Association] did nothing but get together as ministers of God and prayed then that's worthwhile. But if they get together and pray and focus on our needs and bring people in and get research, and get information back to the community, and initiate programs, and have those programs initiated in the churches and in the community, then that's fantastic because that's what we need. We need direction, and we need spiritual direction. If we did not need spiritual direction then all the social service agencies would have worked our problems out. Because a lot of them have been in existence and running strong and they have the funding, and they would have worked the problems out." ${ }^{, 42}$

The Christian Association holds regular monthly meetings as well as additional community meetings, all of which are open to the community. The meetings are a forum for individuals to ask for assistance, and for representatives of government agencies and 
private groups, such as non-profit advocacy organizations, to relate relevant developments that might benefit the community. The meetings provide a way for the pastors to learn new ways of implementing such programs and learn new approaches to old problems. It is also a way for these speakers to lobby pastors to support the agendas of the speakers.

The Association functions as an information clearing house. The Christian Association keeps the community pastors up to date on changes, developments and other information in the wider community that might be relevant to Perrine, by inviting speakers like Commissioner Moss, school principals, Ron Tookes of the police department, and representatives from other agencies and ngos to its monthly meetings. Tookes is instrumental in facilitating the flow of information to the Association by inviting the pastors in the Christian Association to the NRT community meetings and to Commissioner Moss's monthly round table meetings.

Information flows from the Perrine community to its commissioner through the ministers of the Christian Association. Congregants tell their pastors what their needs are and the pastors pass such information on to the commissioner. Commissioner Moss calls the ministers the "eyes and ears of the community." Reflecting the dual role he believes the pastors are assuming in ministering to the spiritual as well as the material needs of their congregants, he refers to them as "pastor-leaders:" they act as pastors when they preach the word and pastor the flock on Sunday, and they act as leaders when they direct individuals with needs to a person, agency or service organization that can help them: "[If] a member goes up to the pastor at the end of Sunday Service and says, Oh, Pastor, you know, how you doing? Oh I'm doin' fine but you know every night these guys on 
my street on the corner be out down the street playing dice, drinking beer, making noise, till two, three in the morning. So then the pastor might hear that and say, well as a leader that's where I'm responsible, as a pastor-leader. You hear that, you need to take action. Either call up Ron Tookes or know the proper channel to get to the West Perrine Christian Association. .. Maybe we call the commissioner. ${ }^{43}$

Requests from residents for a swimming pool, a park, sidewalks, or better lighting, and complaints about overgrown lots and dumping of abandoned cars, tires and washing machines are passed on to the commissioner. Then, Commissioner Moss will work to service the community's needs. For example, he has pushed City Hall for money for a swimming pool or for new sidewalks. He endorsed a larger county wide proposal to create a Disney style theme and water park at the defunct Homestead Air Force Base, south of Perrine, in an effort to develop south Miami Dade County's economy and to create more jobs for his constituents. His office facilitates the speedy resolution of problems like dumping and overgrown lots.

Arguably, Commissioner Moss's greatest achievement in improving Perrine's quality of life has been tied to a large plan for community improvement that incorporates aspects of the earlier plans: the Seventeen Point, Charette, South Dade Neighborhood Development Concept Plan, and Moss Plans, he had helped to design. This large plan is spearheaded by Ed Hanna of the Community Development Corporation with the support of other original of the Richmond Heights group of community leaders members (including also Richardson and Tookes). Besides the large \$73 million FEMA allocation mentioned above, Moss has been able to secure 4.5 million dollars from the State of Florida to build a health center and a youth facility on Homestead Ave. in Perrine. Moss 
also facilitated the purchase of properties on Homestead Avenue bought to house these institutions and for commercial development.

Hanna's efforts to tear down crack houses and eradicate slum landlords also have the backing of Moss's office and the police department. The support of the police is important because the police department enforces code violations against landlords. Moss's office supports Hanna's efforts to improve the existing water and sewer infrastructure. Once improved, the community will become more attractive to new developers, who would not otherwise want to come into the community if they had to be responsible for making the changes necessary to put existing structures and real estate into compliance with building and water and sewer codes. Hanna's redevelopment efforts, backed by the Association and church leaders, aims to lower crime by destroying crack houses and encouraging home ownership over renting. Tookes and Richardson have attempted to use their influence to encourage citizens to upgrade from the older septic tank system to the city sewage system. In turn, it is believed that homeowners will have a greater incentive to take care of the community because of their economic investment. Improvement to the community will also increase tax revenues for the county by raising property values, attracting government funding for Hanna's projects and reducing government long-term expenditures.

The resources Moss has been able to bring to the community shows to all the power and influence of the Association. The Association has succeeded in its requests to the commissioner for help. But in another sense, such success demonstrates that the Association has not only deployed civic social capital to get Moss to respond, but also that the Association has used its civic social capital to enhance the power of the 
commissioner. The pastors added to Moss's influence at City Hall when they assisted him in reducing crime and otherwise improving the image of Perrine and its ability to attract development and to increase tax revenues, and reduce Perrine's need for government assistance in the long run.

The Christian Association's success in generating civic social capital is due in part to its receptivity to information by individuals and groups beyond its immediate sphere. ${ }^{44}$ The Christian Association actively cultivates outside speakers to share new ideas, trends, and developments that might be relevant to their community. The creation of ties beyond the confines of their intimate circle ("weak ties"), besides allowing for more effective information flows, leads to the development of shared interests and common goals among the different social groups, increased levels of trust, and, consequently, an increase in civic social capital. (It is important to note that information that is being communicated to the pastors is often not delivered in a "neutral" manner, but is accompanied by the intent to influence). The following two examples will show pastors in the Christian Association embracing new ideas while overcoming old feelings of distrust. Both examples involve black governmental spokes-people "bridging" their respective institutions with the West Perrine community.

In 1996, when the Welfare Reform Bill was passed during the Clinton administration, and moneys became available for churches to use for social service programs, Ron Tookes saw this as an excellent way to bring government resources into the community. "Charitable Choice," or governmental "faith based initiatives," as this aspect of the Welfare Reform Bill was called, did not find widespread support, however, among many of Perrine's pastors. Some of the churches have had concerns about 
involving the government so directly in their affairs; they are fearful of the potential strings attached to such funds. Unlike Tookes, Richardson and Moss, these pastors believe that only a strict separation between church and state will safeguard the freedom of religious groups to practice their religion freely outside of government control. Past president of the West Perrine Christian Association, Rev. Joseph Sumpter believes that government funding will interfere with the churches' ability to teach the word. ${ }^{45}$ Shirley Green believes that tax auditors will coerce churches to vote for Bush if they have not kept their books in proper order: "Remember, the reason why this United States was established was for religious reason. They came here to be able to serve God in the way they wanted to. It was not established by some atheists who came here sayin, we don't want Church. It was established by church people. ... I feel that the Bush faith based initiatives are to give a little bit of money to the churches and then wait until they are half way operational and then send in special auditors to make all the ministers think they are going to jail around the time of election, so that the ministers can get their black community to vote Bush." 46

Tookes' strong support for the governmentally supported faith based initiatives has convinced many pastors in the Christian Association to use this money in spite of their apprehensions. Tookes has argued that he sees the faith based initiative as an opportunity to take the responsibility away from the government for taking care of the local community and to give it back to the church. He has tried to convince them it is better to get money from the government for the provision of social services by the churches than to have the government supply such social services directly. Tookes has gone as far as bringing in people to teach the church leaders how to write grants to obtain 
governmental and other moneys. There are now churches in Perrine of no more than forty members who have grant writers. The ability of these churches to acquire and then disburse these moneys results in an accumulation and deployment of civic social capital.

A second demonstration of the use of information to generate civic social capital involves a presentation delivered by Tamara Gray (who is black) of the Dade County Juvenile Advocacy Unit of the Public Defenders Office to the West Perrine Christian Association on March 19, 2001. She came to this meeting to speak to the pastors about a policy change in the criminal justice system. ${ }^{47}$ She identified a trend in the juvenile justice system, indicating that the State's policy regarding transfer of juveniles for adult prosecution was being used in a manner discriminatory against blacks. This trend, she said, was accompanied by increased spending by the government for maximum security prisons and spending cuts in juvenile programs like after-school, pre-school and drug counseling programs. She concluded that the government is no longer focused on prevention but on punishment. She outlined grave consequences this trend would have on the black community, including Perrine. Gray ended her presentation with several recommendations. ${ }^{48}$

The first was that citizens should try to change the law. Secondly, she urged the churches to increase their youth programs, e.g., have more baseball games and other activities for youth. But the recommendation about which she was most insistent was that the community should return to its former sense of community, and recognize that every young black male is at risk and that every child needs to be accounted for. She urged the community to look out for every child, for example, to ask a child found unaccompanied, "where's your mother at," and to discipline children if necessary. She 
urged the community to "go out and fish for those children" and bring them back into the community because the numbers are only going to reach higher. ${ }^{49}$

The pastors' viewpoint, that the government was usurping their communal authority, with detrimental consequences to their youth was only strengthened by Gray's presentation. Bishop Watson, affirming and summarizing Ms. Gray's presentation in his customary manner said, "The big picture is 'lock em up." He continued, "I am fifty years old, and I remember when my momma said 'get home." He said he knew he was going to catch it, but he come on home anyway. He said, "Now you can't spank your child. And that is crazy." He related how his daddy used to beat him with a baseball bat, electric cord or whatever he could get his hands on. There was a lot of laughter among the pastors; it seemed that many of them shared his experiences. Bishop Watson continued, saying that the prison system is designed to make money, that it is making money off of black youth, and that money made off of black folk is what is running the system. He ended with, "don't let the government go raising your children." Although some blacks in South Florida ${ }^{51}$ and nation-wide shared Gray's characterization of the criminal justice system as exhibiting a form of institutional racism, the generally positive relationships with the local police that many pastors in Perrine enjoyed tempered their view. Perrine's pastors may have agreed with Gray that black youth in general are being unfairly targeted by the "system," but part of the system is the police force, and they have come to rely on their local police, whom they help to make arrests, understanding that community stability is dependent on law enforcement. The West Perrine Christian Association's religious leadership did not dismiss the "trend" that Gray outlined, however. They offered instead, a theological explanation based on the 
forces of good and evil. This raised the possibility for alliances to form between those in the wider society who shared similar theological orientations, thus bridging inter-racial, socio-economic, and political divides. For Shirley Green, Satan works through the "system:"

There is a conspiracy to destroy especially black males. We really feel there is a conspiracy from the government, but basically from Satan. And he uses the government. He uses everybody. To destroy. There is a plan. ... I was preaching at a prison last month, and it's just so hard when you go to a prison because basically it's all black. And you say, are all crimes in America committed by black men? And then I say, Do any of you brothers know anybody who has a manufacturing firm that makes those tiny little zip lock bags that the crack cocaine and the other drugs come in? No. The only zip lock bags that you know are the ones in Winn Dixie and Publix for sandwiches. So who is making these teeny tiny zip lock bags for crack cocaine and all these other drugs? And then putting these drugs into these teeny tiny zip lock bags and then distributing them to you? Is that not a conspiracy coming from outside of your community? And I ask them another thing. Do any of you have any knowledge of any brothers that have speed boats fast enough to out run the coast guard? No? So that means that somebody with an awful lot of money could buy speedboats fast enough to out run the coast guard to bring drugs into your community to kill you. It's not coming from you. It's a conspiracy. Then I said, I want to know if any of you brothers know any other brothers who has a tanker? A tanker that is big enough to go through Columbia, South America, back around Cuba, then up the Miami River, filled with drugs? You do not have the money. There is no money in th black community to bring these drugs in here to destroy you. They are bringing it in. It is a conspiracy to destroy you. And I say you are buying into the conspiracy. You are using it and you don't think it's destroying you but it is. ${ }^{52}$

The issue of young black males at risk had been identified as a problem by the Perrine community for some time. They have long believed that youth get into trouble because prayer has been removed from the schools, parents have lost their rights to discipline their children, and a generation of black males is being raised by the government in the prison system. The problems surrounding youth, one aspect about which Tamara Gray spoke, has been identified by the Perrine's pastors as a major threat 
to the vitality of the community, impinging on practically every aspect of its functioning. Pastors complain about the problem of children being raised without fathers who are in prison. They are well aware that these youth, especially males, are at great risk because they have no appropriate authority figure and no good role model. The future of the family unit is at risk because such young males do not learn how to become good husbands and fathers. Pastors know how hard it is to find jobs for ex-offenders and that many return to the streets peddling drugs.

Gray's presence at the meeting is yet another example of a representative from a governmental institution connecting to this church-based group. The information she shares with the ministers endorses their viewpoint and helps to focus their energies on devising strategies for addressing the future of their community. Suggestions, such as were offered by Tamara Gray, would find themselves incorporated in church-based institutional solutions to these problems.

\section{A "War of Religion"}

West Perrine Christian Association president Bishop Simeon Watson proclaimed at one of its meetings, "There are two governments: White House government and Jesus is our government." By this remark, Watson effectively delineated the zone of conflict between Perrine's churches and the dominant society. By the 1990s Perrine's confederation of churches saw their struggle as being less a struggle against racism and more a struggle against the harmful secular values promoted and endorsed by the dominant society. Delores Alexander expressed this view when she noted that churches 
were involved in a "war of religion," that "the religion of secular humanism has been at war with the faith as we knew it." ${ }^{, 53}$ Mr. Finkley's criticism that Hanna's efforts to encourage home ownership by offering mortgages encouraged the "get rich quick mentality," a secular influence, to take hold in Perrine was part of this struggle. ${ }^{54}$ So was the desire expressed by many in Perrine's church community that prayer be re-instituted in the public schools and that people be permitted to pray in the name of Jesus at public functions.

They get this thing called you can't pray Jesus name. I'm sayin, you're not prayin. You talkin to Jehovah. You're not prayin. Cause He said, whatever you ask in my name, he'll do it. I have no problem with you be a Catholic, and they ask you to pray. You pray to Mary all you want. That's you. I have no problem if they ask a Hindu to pray. That's him. When it come to people sayin they supposed to be Christians and this is what I look at religion at, because they don't want to hurt nobody's feeling, and they pray to the God of the Universe, and all that kind of stuff. Never talk about Jesus. You ain't sayin nothin. So you're a Christian at our church but you're a hypocrite in the street. ${ }^{55}$

The Pentecostal/Holiness tradition (also referred to as the Sanctified Church tradition), of which the Pentecostal, Holiness, and Apostolic Churches in Perrine are a part, embody these anti-secular sentiments. Although there is a range in orientations towards secular society within this religious tradition, the churches in the West Perrine Christian Association do not mandate a separation from secular society as a prerequisite to living a holy life. Elder Bennett, one of the pastors in the Association, reminded members at one of its meetings that people "can live holy" in this world, and that they can and should live a life of full civic engagement. ${ }^{56}$ The problems in society, the teen pregnancies, the shootings in schools, children not listening to their parents, problems in the government and in the churches, are seen, according to Pentecostal doctrine, as 
stemming from one cause: People don't live holy lives. God must be put back into people's lives. As Bennett offers, "God is the solution to the problem."

When churches do battle with "secular" society, they accumulate civic social capital. The following is an example showing how the Perrine group of pastors earned a considerable amount of civic social capital through this conflict with secular society.

Bishop Watson, as president of the West Perrine Christian Association, attended Commissioner Dennis Moss's monthly round table meeting at City Hall and related the following:

I went to the Commission. Dennis Moss. I went to the round table meeting. And I came in there, and they come to me and they say, Bishop Watson, we'd like for you to pray today. And by the way, you don't mention Jesus. I say, by the way, I don't pray them kind of prayers. He said, okay, do what you want to do. So when Commissioner Moss, when they gave him my name to pray, they say, Bishop Watson, we gonna have you to pray. Now you know we don't do that. And I hollered back out to them, Commissioner, I don't pray them kind of prayers. He said, go ahead Bishop. And when I got through prayin, you know, the way I supposed to pray, you'd be surprised that Washington ${ }^{57}$ was there, well they come to me and say, praise the Lord. 'Bout time you got someone here to pray. ${ }^{58}$

\section{Religious Institutional Responses to Social Problems}

It was not until after the Lee Arthur Lawrence murder, when Perrine's churches came together in common cause to improve their community, that individual institutional responses were devised to combat the effects of broader societal forces believed to be harming Perrine's community. The importance of the family, including the welfare, education, and safety of its youth had always been a one of the most cherished values of the Perrine community. Yet this important value was being eroded, as evidenced by such 
social pathologies as divorce, teen pregnancies, substance abuse, school failures, criminal behavior, homicide, physical and mental illness, AIDs, and domestic violence.

When Perrine's churches reunited with one another, they also reenforced their connection to the broader black community through more extensive networks, including those of the larger black church denominations and other black institutions. During the 1980s, coalitions of large black institutions had begun to formulate a post-civil rights era political agenda that included the strengthening of the black family as one of its primary goals. Perrine's churches were able to tap into this coalition's resources by becoming the recipients of vast quantities of information. Connecting to the larger black community enabled Perrine's churches to increase their civic social capital by defining and shaping their own agenda, and by learning new strategies, in the form of church programs and other initiatives to achieve these goals.

This new agenda capped several decades of debate touched off by two publications in the 1960s, as the last of the civil rights bills was passed by Congress. There was a growing realization of the limitations of these laws as an effective force in the final solution of the civil rights problem. For although legal racism was destroyed in the United States between the years 1954 and 1965, these years also marked the development of de facto segregation across America. Its effects and the subtle racism that accompanied it was deeply embedded in most of America's socio-economic institutions.

The first of these controversial publications, Daniel Patrick Moynihan's famous study, The Negro Family: The Case for National Action, ${ }^{59}$ otherwise referred to as the Moynihan Report was released in 1965. It identified the breakdown of family ties in poor 
neighborhoods as being more significant in explaining ghetto pathologies than joblessness. The second was the introduction to a new edition of E. Franklin Frazier's The Negro Family in the United States (originally published in 1939) written by sociologist Nathan Glazer, who had collaborated with Moynihan in a 1963 study on ethnic and racial groups in New York, Beyond the Melting Pot. Glazer believed that there needed to be more of an interaction between government and families as part of the solution to the civil rights problem, although he wasn't sure what this meant in terms of policy. He wondered which factor would have the greater influence on alleviating ghetto pathologies, government initiatives in the form of monetary assistance and job creation, or strengthening the family. He wrote, "It is clear that society makes families and families make society, but what is not clear is the relative influence of the two." ${ }^{60}$ The resulting black agenda, fashioned in the 1980s, affirming Glazier's and Moynihan's insights, was a two-pronged approach: black churches and other institutions would establish programs to restore the viability of the black family, and in the process, would seek to harness the resources of broader society, including the government, private business, voluntary non-sectarian and religious sectors in a collaborative effort to reach that goal.

One of the earliest formulations of this new black political agenda took place in 1984 when the nation's two oldest and largest black national organizations, the NAACP and the National Urban League, sponsored a national black family summit at Fisk University. Many national black organizations were represented at this summit and their leaders were advised to address the black family crisis as a national problem of the utmost importance. When these leaders, professionals, activists, theologians, historians, 
and social-science scholars who study families returned to their organizations, they began to focus their efforts on black families. ${ }^{61}$ Churches, in their own way, began to adapt their institutional structures towards this goal, leading an editorialist at the New York Times on May 23, 1988 to note that "increasingly, the black churches have stepped in to try to repair the breaches in Black family life left by social, economic, and political change. Their efforts range from complex foundation-supported child development programs to simple but sensible adopt-a-family projects." ${ }^{, 62}$

Three years later, the "family crisis" was placed on the agenda of the largest black organization in the nation, the 8.7 million member National Baptist Convention U.S.A. In 1991, at this institution's annual convention, its president, the Rev. T. J. Jemison, addressed 40,000 delegates representing 33,000 churches and 100,000 pastors, announcing that the group would give the highest priority to the family in the years ahead. ${ }^{63}$ Across the nation, the black church was forming its response to its most pressing social problems by focusing its attention inward, toward repairing the basic building block of the black community, the family unit.

This chapter explores some of the responses by Perrine's churches to the future of their community - their youth, since the time of the Lee Arthur Lawrence murder. In many instances churches have stepped forward to assume the role of the family. When families were stronger, they were able to contribute to raising and nurturing their children, to shaping their characters, and to developing their sense of social and individual responsibility. Now churches shoulder much of this burden by themselves. Churches have bolstered their youth ministries, hiring youth ministers who look for innovative ways to attract youth to church life. Youth ministries provide education and 
fun activities (like trips to amusement parks). They encourage community service (as tutors, volunteers in hospitals and nursing homes, and helpers in food banks), train young people to lead church services, and promote the formation of youth counsels where young people practice the skills of governing. Christian theology provides the framework for participation in civic life. Youth ministries offer the hands-on training young people need to insure this participation.

\section{Churches Function as the Family}

Tamara Gray's recommendation that churches look out for the community's atrisk young males resonated with Perrine's church leadership. Providing an alternative to the destructive gangs to which many lonely, loveless youth are drawn, churches often function as a surrogate for families, establishing rules and providing father figures for young men, men who offer both the personal attention and the much needed authority these youth lack at home. Shirley Green, pastoral counselor of Community Church of Christ Written in Heaven notes, "Sometimes the church has to be the father. And to take on the disciplinarian role. We don't go so far as to spank them, but we put the fear of God in them. We do almost anything that would be found in a nurturing, functional family. . We find some minister, or some deacon in the church that will do it." Churches re-connect young people to an earlier set of community values all but lost by family disruptions. In many cases, the family unit is not the accepted norm among young people. Churches look to pair young people with mentors to show them that family life, fatherhood, and honest hard work are plausible. Rev. Norman Freeman, 
youth pastor of Sweet Home Missionary Baptist Church mentored one high school student who lived with his mother, bringing him to his home to see "the proper way to treat a woman." Believing that he possessed excellent leadership skills, Rev. Freeman also had him accompany him as he attended to his ministerial duties. Sweet Home also promotes the Omega Psi Phi Fraternity, a mentoring program designed for male youth who have no male role model at home. One of this organization's activities includes taking high school students on college tours. ${ }^{65}$

Bible classes, held in virtually all the churches, are also used to teach family values. Youth are taught to recognize unhealthy relationships and encouraged to develop appropriate ones. Emmanuel Apostolic, and Perrine New Testament Church of God, Perrine's two Jamaican churches, hold weekly classes for singles to teach young people about dating, sexual abstinence before marriage, courtship, marriage, and the importance of education so men can provide for the family's economic security. ${ }^{66}$ At Sweet Home, one Bible Study class a month is devoted to problem solving within a Christian framework. At one such meeting high school students were asked to present to the class a problem they were wrestling with. Then other students were encouraged to find a Biblical solution to this problem. Youth pastor Rev. Freeman guided them in working out issues relating to dating, sex, parents, relationships with peers, and problems at school in accordance with Christian principles. He emphasized healthy relationships, proper sexual conduct, ways to overcome peer pressure and the importance of prioritizing time so as to devote enough attention to school work. ${ }^{67}$

Churches compete with street culture as they try to interest young people in finishing high school and attending college. Some churches honor their high school 
graduates with a special service in June dedicated to them. Community Church of Christ Written in Heaven gives graduates the proceeds from monies collected at church on the Sunday their graduation ceremony is held. Sweet Home awards all high school graduates $\$ 500$ if they go to college. But as Rev. Richardson says, peer pressure is difficult to overcome: "If you're a boy, and you're seventeen and most of your peers have not graduated high school and they're successful at selling drugs and making money in other kinds of ways, and stealing cars, why do you go to a program with a white robe on and tell folks, I've made it, when in fact that's not your measure of success. Making it out of high school is not a measure of success in Perrine.,"68

\section{Cultural Relevance}

Youth ministers must be in touch with contemporary culture in order to compete with the "secular" world for youth attention. Music is an important avenue through which churches are able to reach young people. The skilled music minister who can effectively introduce contemporary music into the church service and into the youth choir repertoire is highly valued. The music used in many of Perrine's churches show the Pentecostal influence in instrumentation, music selection and forms of music.

Pentecostal churches used musical instruments in their worship services that were for many years prohibited in main-line denominations. First introducing drums, tambourines, and scrub bows, later they added the electric guitar and other percussion instruments used in popular, secular music. 
For years, this instrumentation was a point of contention between the Pentecostal and main-line denominations. Today, virtually all of Perrine's churches have adopted these instruments as part of their worship services. Pentecostal influence also extends to the more energetic, up-beat contemporary gospel style and the "praise team" form of worship that Pentecostals initiated. Praise teams, groups of three or four men or women at microphones leading the devotional parts of the service have been added to or have replaced the traditional "devotional" led by deacons in the traditional Southern black church. ${ }^{69}$ For example, at Sweet Home, the 8:00 Sunday morning service opens with an elderly deacon (originally from Georgia) singing devotional hymns using the old style "lining" form. The devotional hymn segues into a Spiritual, and then into a lively gospel number, perhaps led by a praise team with Rev. Richardson himself, an accomplished musician at the piano. Some of this contemporary gospel music is particularly dynamic, utilizing elements of R\&B, rock, blues, and jazz. In one service I attended at St. Peter's Missionary Baptist Church, where the music was especially driving, Rev. Sumpter announced that the "spirit is so high here today" that he was going to forgo the sermon and replace it with another musical number. ${ }^{70}$ The Jamaican churches, about which more will be said later, incorporate reggae music and British-based folk songs into their services along with contemporary gospel, and spirituals.

Youth are encouraged to express themselves by incorporating contemporary cultural forms into special youth worship services they lead. As leaders of praise teams, young people have introduced new forms of expression into the church service. For example, at Sweet Home, youth praise teams have used step-dancing, miming, ju jitsu 
and junkanoo (a Bahamian ritual dance) ${ }^{71}$ in what can be thought of as new forms of worship. $^{72}$

\section{Development of Civic Responsibility and Civic Skills in Youth}

Youth ministries are designed to encourage youth participation in the church community by actively cultivating their leadership abilities. Many churches, like Sweet Home, have youth services once a month where youth lead praise teams, perform plays, give presentations, sing in youth choirs, act as ushers, and help to design the service. At other churches, like Community Church of Christ Written in Heaven and the Jamaican Emmanuel Apostolic youth are an integral part of the Sunday morning worship service. At Emmanuel Apostolic, children regularly run much of the service as members of the band, as ushers, as solo singers, and even as Sunday school teachers. ${ }^{73}$ This church has been successful in cultivating the leadership abilities of Ramon Gordon, son of the pastor at Emmanuel Apostolic. Ramon teaches Sunday school, plays in the band, and helps to run the services at his father's church. He is also active at the Coral Reef High School Bible Class, about which more will said.

Many churches develop leadership skills of their youth by helping them to organize and run youth counsels. At a youth group meeting on 2 Oct. 2000 at Sweet Home, the youth minister, Rev. Freeman was helping teenagers to form a youth counsel. He told them he wanted them to run their organization, decide on the form of organization, and the programs they want to implement. At this initial meeting there was a discussion, initiated by students, as to whether there should be a board of directors or a 
parliamentarian system of government. Students seemed to have had experience with both forms of organization through their involvement in clubs at their high school. ${ }^{74}$ Other churches like Community Church of Christ Written in Heaven and Mount Moriah Missionary Baptist Church, also had youth counsels but their youth directors gave their young people far less latitude in governing themselves. ${ }^{75}$

Youth ministers encourage community service by way of volunteering in hospitals and nursing homes, helping in food banks, and tutoring. Indeed, at Sweet Home's youth group meeting mentioned above, one girl suggested that her youth counsel initiate a tutoring program for West Perrine's children. Churches provide the avenues by which students can fulfill their requirements for high school community service hours.

An outgrowth of the several youth ministries is the Bible Class run by black youth at the local Coral Reef High School, located in Richmond Heights. This Bible class is held during the lunch hour one day a week and is organized as a school club, with students serving as officers. Pastor Shepherd, the youth minister of Bethel Full Gospel Ministry in Richmond Heights, and Rev. Freeman of Sweet Home served as consultants during the time of this research. The Bible Club, originally formed by white youth, was now about $95 \%$ black. The meeting on 24 October, 2000 was attended by approximately a hundred students, all packed into a classroom. The meeting opened and closed with a student delivering a prayer. Lunch was provided by Sweet Home and Bethel. The club served as opportunity for youth from different churches and socio-economic levels to exchange ideas, and to participate in a joint type of government. Ramon Gordon, the son of Rev. Gordon of the West Perrine's Jamaican church, Emmanuel Apostolic, has shown his outstanding abilities at this club as a talented preacher. ${ }^{76}$ 
The subject this Bible Club explored is a good illustration of how two black churches, one in West Perrine and one in Richmond Heights, attempt to help youth understand secular culture in light of Christian principles. The subject of this meeting was Halloween, which was a week away. Pastor Shepherd presented an overview of Halloween. Afterwards she led a discussion, which included "testimonies" by students.

Halloween, she told the students, originated with the Druids, who lived in England two centuries before Christ. The Druids performed human sacrifices, a practice which allowed trapped spirits to be released. Every year, beginning in September, trapped spirits, in the form of witches and warlocks begin to fast so that they are ready to eat. Then they use magic and curses to trap and kill their prey. In England, the Druids offered human sacrifices to the Sun God, the Lord of the Dead, otherwise known as Pan. Pope Gregory converted this practice into a holiday which he called All Saint's Day. It was eventually made into a universal Roman Catholic Church observance called All Hallows Eve. America's founding fathers objected to this holiday and it was not practiced in the United States. But in 1840 when a potato famine in Ireland brought Irish immigrants to America, they brought Halloween with them. Originally a celebration of the fall harvest, Halloween now offers an opportunity for Satanic cults to try to aid the spirits' release. Satanic spirits are attracted to lighted pumpkins, food and candy. Razors and other dangerous objects are often placed into candy in order to kill children so that spirits can feast on them. She said that an average of 1600 children per year die or go missing each Halloween.

Pastor Shepard told the students that she once went to Key West on October 31 and witnessed "Fantasy Fest," a parade for which residents prepare for a year. She 
described the parade, a float that carried a huge beast with people bowing down to it, praising Pan and worshiping Satan. She said that Satan is very hungry as he starts fasting in September and that his hunger why there is so much abuse and so many deaths among children. The discussion that followed emphasized prayer, fasting and Bible Study as protection against evil influences. Students testified that spiritual strength, including "being saved" guards against evil spirits. ${ }^{77}$

\section{Strengthening Black Identity through Studying Black History}

One of the methods Perrine's churches have used to restore broken ties between The generations has been to teach youth about their heritage by studying "black history." Churches throughout Perrine, including the two immigrant Jamaican churches, celebrate Black History Month during the month of February. Black History Month is a festive affair in West Perrine. Many congregants wear African clothing at Sunday services and churches participate in joint programs during the week. Sunday services are opportunities for young people to learn about their heritage through presentations they make to their congregations: youth write and perform plays, design their own costumes, tell stories and give reports on events and people important in black history. The following two examples provide a glimpse of how two different churches, one a mainline church with a predominantly middle-class membership (Sweet Home), the other an immigrant Jamaican Church (Emmanuel Apostolic) sought to strengthen black identity as they celebrated Black History Month in February of 2001. 
The first example involves a sermon by Sweet Home Youth Minister Rev.

Norman Freeman, a seminary-trained minister who has since left Sweet Home to pastor his own church in Homestead, Florida. ${ }^{78}$ The sermon, directed as much toward parents as to young people, was delivered at Sweet Home's monthly youth service where many parents were in attendance. Rev. Freeman spoke about black educator and scholar Carter G. Woodson, (born 1875) who initiated Black History Month. Woodson's book, "The Mis-education of the Negro" detailed how schools, social service agencies and the entertainment industry contribute to the mis-education of young people. Rev. Freeman pointed out that Woodson's observations are as true today as they were in his time. Focusing on the entertainment industry, Rev. Freeman outlined how television, movies and rap music expose young people to drugs, sex and violence. For example, the industry seems to tell youth that it is all right to lie and cheat, and that homosexuality is okay because it is an "alternate life style." Rev. Freeman warned parents that young people are adopting many of these values. He reminded them that these popular values run contrary to Biblical teachings, pointing out that according to Genesis 26 and 27 , man was created in God's image. He told them that today, young people are being created in the entertainment industry's image. Youth, he said, look like they are reproductions from the prison system. In prison they learn to wear their "pants hanging down, so far down that you can see their underwear, and have body piercings and tatoos." Youth, he says, need to know that they are not made in the image of Puff Daddy, Snoop Doggee Dog or Brittany Spears, but in the image of God. Rev. Freeman tells parents that it is time for the church and the family to re-educate their youth, to make them understand why they were created and to change their image of themselves. This "image problem," he said, 
can be countered by teaching children who they are and who they came from, and by

helping them to understand their strengths by seeing how they have been able to

overcome adversity. Freeman proclaimed: "we have a story problem."

There are a lot of people telling kids who they are, but we have to tell our story because it's healthy for their psyche. Woodson said that if you control a man's thinking, you don't have to worry about his actions. When you determine what a man shall be, you don't have to concern yourself about what he will do because his mind is in chains, in bondage. We have to tell our story, about how a slave endures his fight. So many of our youth feel that they are inferior to other races, but they need to know that in spite of all their circumstances, their grandparents and great-grandparents survived because they not only had strong bodies but they had strong minds. Before slavery we were a great people. They tried to break us psychologically. But the slave had what was called the "invisible church." They would go down by the riverside and go talk to God. Their minds stayed on Jesus. They said, "master can work my body but God has my mind." Our children need to know that we have endured pain psychologically but God sustained us spiritually. We have to tell our story. Our story has rich heritage.

Our story is about production workers who toil to put their children through college, preachers, architects, entrepreneurs and others. We need to tell the young people that they are genetically linked to greatness. You come from a great people. You come from kings and queens: King Tut, the Nubian king who controlled the largest empire in Africa at the age of sixteen. You come from a great people, people like Queen Cleopatra who spoke many languages and, hello people, mastered many African dialects. You come from a great people. You come from liberators like Frederick Douglass, Nat Turner, Marcus Garvey, Malcolm X, MLK, Sojourner Truth, Harriet Tubman. ... We weren't always the drug addicts, pimps. We built the pyramids.

Rev. Freeman encouraged parents to become more involved in re-educating their children to the positive elements of their heritage. He urged them to tell their children their own family histories. Then he invoked the Biblical idea of covenant, declaring that as God made a covenant with his people, this sermon should serve as the beginning of a covenant between parents and their children. 
A second example of the use of black history to build identity involves one of Perrine's immigrant churches, the Jamaican Emmanual Apostolic. As Bahamian and American blacks maintained a separation through their respective churches throughout the first sixty years of Perrine's history, so is the pattern repeated today with Jamaicans and African-Americans maintaining distinctively separate churches. This example is interesting, in part, because of how the Jamaican perspective concerning race and civic involvement on both a local and national level differs from that of Perrine's American blacks, and also because it shows how this immigrant group has attempted to enter American society.

First, a short introduction to the Jamaican presence in Perrine and the formation of Perrine's two Jamaican churches. Jamaicans began arriving in South Florida in the 1970s and their numbers have been steadily increasing over the past thirty years. Jamaicans came to Miami seeking greater economic opportunity and because of growing social instability in Jamaica. Two Jamaican churches, one Pentecostal, Perrine New Testament Church of God, (established 1979 by Rev. Walden, who arrived in South Dade in 1976), ${ }^{79}$ and the other an Apostolic church, Emmanual Apostolic (established in 1991 by Rev. Gordon, who arrived in South Dade in 1984$)^{80}$ were established in West Perrine for Jamaicans streaming into South Dade County ${ }^{81}$ Congregants at these two churches maintain strong trans-national ties with a constant flow of family members and visiting pastors back and forth between Perrine and the Island.

These churches exhibit the class and socio-economic stratification indigenous to both Jamaican and American society. Differences in religious practices serve to reenforce class differences, reflecting a similar tendency in American religions. The 
Church of God represents a strata embodying a set of more upwardly mobile values, including the importance of material wealth and class status, and with a desire to assimilate into America's middle class. Its membership includes a high percentage of well-educated professionals - nurses, school teachers, lawyers. Indications of this group's value system include its large, affluent-looking church building, an emphasis on decorum in the worship service (despite its Pentecostal affiliation), and a more relaxed dress code (women wear jewelry, not all wear hats, and not all men wear suits) ${ }^{82}$ Former member, Vanessa McCloud (pseud.) left this church because she did not want to be judged by the type of car she drives or by her profession (a nurse). Wanting to experience the cultural diversity of her new country, she joined Perrine First Baptist Church, a racially mixed church with a white pastor and large Jamaican membership just east of West Perrine across US Highway 1, but eventually wound up at the AfricanAmerican Bethel Full Gospel Church in Richmond Heights. ${ }^{83}$

A second strata is represented by Emmanual Apostolic, a store-front church, which, although its membership includes well-educated professionals and others, appears to have a greater concentration of working class members than does Church of God. Worship services exhibit more emotional intensity, less structure, and more vibrant music than at Church of God. Congregants' dress is more in line with Pentecostal tradition: women all wear head coverings and modest dresses to church services and they do not wear jewelry. Bible classes emphasize religious piety, moral development and discipline, family responsibility and the awareness of building God's Kingdom on Earth. ${ }^{84}$

Pastors and others in Perrine's African-American church community have criticized the Jamaican churches for what they perceive to be a lack of community 
involvement and a self-imposed separation from African-Americans. Rev. Walden's church did not become involved in Richardson's clean-up efforts in Perrine prior to and after the Lawrence murder. Rev. Richardson complains that "they are not involved in the community struggle. They are about as disconnected from this community as the Muslim mosque right next to the Walden's [Perrine New Testament Church of God]." "Jamaicans," he continues, "consider themselves Jamaicans. They don't consider themselves blacks." The reason, he posits, is because they did not struggle with racism in Jamaica. They "come from a place of power in Jamaica. The Governor is black, the people in the Parliament are black. There's no problem in Jamaica, not with racism." That is why, he says, "I don't have that many Jamaicans here in my church. Because my theme here is social justice." But, he believes, Jamaicans should realize that in America they are faced with racism: "We got similar struggles, man. You know, if you don't believe me, try to do your house over on the East Side of the highway in a very nice community. You're going to get some real funny stares. And Walden, he knows that. He knows it because he's my neighbor. And he knows that he and I both have to overcome." 85

Both Jamaican pastors, however, consider themselves very much a part of American society. They feel a special fondness for Perrine and they believe that Jamaican culture can make a valuable contribution to their new society. In response to the criticism that they do not tend to be politically active, they acknowledge that they are not involved politically in the same way as are many of the African-American churches in Perrine, but they maintain as the reason, that Jamaicans have an antipathy for politics because of their exposure to widespread political corruption in their homeland. Since the 1970s, when 
politicians began to routinely recruit armed neighborhood gangs to rustle up votes, Jamaicans have watched a system evolve whereby businesses, the army, and police are held hostage to gangs amidst rising violent crime and in an atmosphere of fear and recrimination. ${ }^{86}$

Instead of African-American style political involvement, Jamaicans believe they can make a positive impact on American society by way of their culture. Pastor Gordon explains that he founded his church to provide a place for Jamaican culture but at the same time he encourages cultural diversity: "I do not want for this church only to be a Jamaican church. I want people of all cultures to be a part of this church. And that's what we are building right now. We have several Antiguans, Trinidadins, and Americans as well as Jamaicans." 87

Gordon's sentiments are embodied in the Jamaican motto, "out of many, one people," a creed that expresses a Jamaican commitment to accepting cultural diversity while preserving individual identity. The sanctuary of Perrine New Testament Church of God, displaying twenty flags from as many countries, expresses this concept and also suggests the belief that Jamaicans are on equal footing with other ethnic groups that make up America's cultural landscape. Also demonstrating this idea is the fact that both Jamaican churches incorporate a diversity of musical styles, including reggae, gospel, American, British, and African-based folk songs, and Negro Spirituals, into their worship services. Pastor Gordon believes that reggae is one of many important Jamaican contributions to society: "It's the rhythm that we have. That's why reggae music was so popular throughout the world, you know. It's being vibrant in what we do in our 
worship. We put a lot into our worship. We put a lot into our music, and people like that. Just the rhythm that we have that a lot of other people don't have."

Another contribution Jamaicans make is one that Ron Tookes, in an earlier section, applauded, but that others, like Richardson, view as Jamaican superiority: the Jamaican attitude toward work and welfare. Pastor Gordon counters Richardson's criticism: "We don't consider ourselves better than the African Americans. You know, I think some Americans, I wouldn't say, all, we come to this country. We don't expect that America owes us anything, right. We come and work. We accomplish whatever we want to accomplish. We don't sit back and wait. We don't believe in welfare. We refuse to take welfare. We refuse to go on unemployment. We don't believe in that kind of stuff. That's why they might think that we are stand offish, or that we think we're better than what we're not but our pride wouldn't allow us to join a food stamp line."

On Feb. 11, 2001, Emmanuel Apostolic celebrated their first "culture day" during Black History month. Congregants dressed in traditional African dress. The service featured presentations by youth of all ages. One presentation told about the civil rights struggle, including descriptions of the demonstrations, boycotts and freedom rides to end segregation and the role played by courageous black leaders including Martin Luther King. This was followed by a second presentation, a poem delivered by a young girl using the metaphor of different flowers coming together to produce a harmonious bouquet. The poem compared the beauty of individual flowers to people from different countries, with many voices, many opinions, and many customs. They can be appreciated individually, but when they come together they make one harmonious whole, under God. ${ }^{88}$ 
This was an example of an immigrant Jamaican church, joining their community in celebrating a very American event, that of Black History month. The Jamaicans acknowledged that they owed a debt of gratitude to American blacks who laid the groundwork for their arrival to a country where they could find economic prosperity and political freedom. But according to the Jamaican perspective, the African American freedom-fighters were but one flower, albeit an important one, in the bouquet of African culture. The Jamaican contribution, with its music, its strong family values, and its work ethic is also an important flower in this bouquet. The designation of "culture day," rather than "African American Day" or "Black History Day," pointed to the message this Jamaican church was making, as was the message the young girl wished to impart: Preserve your distinctiveness but join together as a whole. ${ }^{89}$

Of the three original cultural streams that settled Perrine, American blacks from northern Florida and Georgia, Bahamian blacks, and American Indian, the American and Bahamian blacks retain much of their distinctiveness. Bahamian culture, for example, is reflected in the bright colors many Bahamians paint their homes, their food (many Bahamians still eat pigeon peas), and practices like the junkanoo. But there is considerable intermixing of the ethnic groups: Endogamy is not as important as it once was and church membership is more mixed. One example of this later point is the membership of St. Peter's Missionary Baptist Church which was originally formed as a Bahamian church but today is largely American. Nevertheless, the distinctions are evident enough for the elderly Fannie Mae Williams (who attends St. Peters) to say, "Nassaus, I enjoy having church with them as much as they enjoy having church with 
me. . I go to Nassau every Wednesday to see the prayers there and I enjoy going to church with them.,"90

It is in their political focus that American and Bahamian blacks share a similar orientation. Although these groups originated in very different racial environments, their experiences in America contributed to the formation of an African-American identity, fashioned from their dealings with racism. The Jamaican struggle, in contrast, is more economic and less racially driven. They have entered American society at a later stage of its development. They maintain a negative bias against political involvement because of their experiences in their country of origin.

\section{The Use of Religious Ritual to Generate Civic Social Capital By Mapping a Collective Political Understanding}

This section will demonstrate how two religious rituals, which are central to African American religious practice, prayer and "preaching the Word," are utilized to generate civic social capital. As instruments of social and political change, churches in the black community have always wielded power outside the realm of the spiritual, but as inherently religious institutions, black churches have accumulated power, that is, civic social capital, in a manner unique to them. They have accumulated civic social capital through religious ritual, including prayer. Prayer and ritual have been used to unify membership and community, to define community, to establish goals, to incite, empower, and transform. 
The latter function, transformation, is a process by which the group restructures itself, abandons old ineffective ways of responding to problems and creates new responses to problems. Two rituals, prayer and "preaching the Word" illustrate how religious transformation is linked to political transformation, and how civic social capital is accumulated in the religious sphere and spent in the political sphere.

\section{Prayer}

The traditional African American unstructured prayer, used freely at meetings and at church services, is a vehicle for transformation, and is in itself an act of empowerment. Because the African American community does not see a separation between the civic and the religious, prayer in this setting is both an expression of civic social capital and a mechanism through which civic social capital is deployed. Through prayer, the community is defined and its needs are articulated. It is an introspective process, a way of refining and clarifying what one is, what one should be, and how that transformation should occur.

Praying together, the longings and self-understanding of the individual become the longings and self-understanding of the group. Individuals identify with and conceive of themselves as part of their communities and are defined by their committed relationship to God. An important component to prayer and worship in general is the acknowledgment that all power resides with God. When the community commits to being a partner with the all-powerful, their power increases. 
The following unstructured prayer delivered at a Sunday worship service at Sweet Home Missionary Baptist Church ${ }^{91}$ by one of its ministers illustrates how the spiritual is intertwined with the social, the economic, and the political:

Lord is good. Let us pray.

Most righteous one, we come this morning Heavenly Father As we should come, Heavenly Father

Knowing, Heavenly Father, that you have all power in your hands, Heavenly Father

Knowing, Heavenly Father, that we can do nothing without you, Heavenly Father Knowing that you rule over the universe and over the earth, Heavenly Father You know those that are sick today, Heavenly Father You know better than the doctors, Heavenly Father Because you have all power in your hands, Heavenly Father We want you to come by and see about us this morning Heavenly Father Because you have all power in hour hands, Heavenly Father Please, Lord, have mercy upon us, Heavenly Father We realize this morning that we are living in dangerous times, Heavenly Father We are living in a time when children don't want to do right

But you know our children, Heavenly Father, you know all about us, Heavenly Father

Please have mercy upon us Heavenly Father

Have mercy on them, please Heavenly Father come see about us

We got wayward children, Heavenly Father, We got wayward parents, Heavenly Father

Have mercy on us Heavenly Father

May your children, on the street, Heavenly Father, You know all about it, Heavenly Father

Some on the street, Heavenly Father, asking for a nickel and dime, Heavenly Father

But you know they are going out and they are coming in Heavenly Father Please Lord, wake them up and show them their sense and their duty, Heavenly Father

Let them know this morning, Heavenly Father, that they have to serve you Heavenly Father

No, one else, but you Heavenly Father

Have mercy on us, Heavenly Father

Want you to bless this Church, Heavenly Father

Never mind the material things, Heavenly Father

But your name, Heavenly Father, your name, Heavenly Father

How many, this morning ...

Please have mercy, Heavenly Father, don't forget about us, Heavenly Father Thank you for the food you put on our tables every morning, Heavenly Father 
Sometimes we, Heavenly Father we don't say thank you for the food, Heavenly Father

But this morning, Heavenly Father, we say thank you, Heavenly Father, thank you, Heavenly Father, thank you, Heavenly Father

Thank you for last night lying down, Heavenly Father

Sometimes when we get up and don't say thank you, Heavenly Father

But this morning we going to say thank you Heavenly Father

For our rising this morning, Heavenly Father

Have mercy, this morning, Heavenly Father

Thank you for shelter last night, Heavenly Father

Please Lord, have mercy, Heavenly Father

Come by and see about us, Heavenly Father

Thank you for jobs this morning, Heavenly Father

Some of us don't have jobs, Heavenly Father

Bless my family, Heavenly Father

Bless the families of everyone here, Heavenly Father

$\cdots$

Some of us are living in a house, not a home, Heavenly Father

Make our house a home, Heavenly Father

...

Have mercy on those who are getting old and weak, Heavenly Father

Some have served you well in their days, Heavenly Father

…

We just want to say have mercy, Heavenly Father

Bless us in Jesus's name. Amen. ${ }^{92}$

Throughout this prayer, and interspersed among the praise, confession, thanksgiving, affirmative responses from the congregants, and supplication, a picture is painted of a people who live in dangerous times and often must fear for their lives. They are a community who come from and live in broken homes, have children and parents who do not behave morally, do not all have jobs and are some of them so poor that they have to beg on the streets. They sometimes go hungry and without shelter, and often are sick and un-cared for as they age.

Expressed along with their needs are the desires and goals to which the group aspires. These are the beginnings of the transformation process that will lead to civic 
engagement. The prayer express the hope that the community, their children and families, will come to know and serve their Heavenly Father. When they do this, He will "wake them up and show them their sense and their duty." Then it will be the combination of the Heavenly Father's mercy as well as His guidance that will lead man to do His Work in the world. The community's association of their social goals with the goals of the All Powerful lends legitimacy to the group's political work.

Preaching "The Word"

Another example of the use of ritual to link religious transformation to political transformation can be illustrated by an important ritual and central feature of the African American worship service, the preaching of "The Word" of God." This ritual also demonstrates how civic social capital is accumulated in the religious sphere and converted to the political.

The climax of the black church service, also known as "having church," is the preacher's sermon. Although the process of preaching is considered to be a collaborative effort between the preacher and God, it is finally God who speaks through the medium of the sermon. In the Pentecostal tradition, there is an added component to preaching, the presence of the Holy Spirit. The ultimate purpose of the Pentecostal worship service is realized when, according to Pentecostals, there has been an "annointing of the Holy Spirit," also referred to as a spiritual baptism. "Having church" can occur in settings outside of the church worship service, such as at concerts, plays, lectures or political events. Community members at the NRT meeting held in Perrine's police station were 
"having church." According to Cheryl Sanders, there are three components necessary for this experience: "a ministering actor or artist, a responsive audience, and a spiritual annointing of divine manifestation or presence." 93

According to Pentecostals, preaching "The Word of God," is listed in Corinthians I as one of the "gifts of the Holy Spirit." This ritual begins by the preacher (or actor) or a congregant (or audience member) reading a section of Scripture out loud. Throughout the ritual, the congregation/audience interacts with the preacher, verbally and through body motions. If the ritual is successful, the preacher/actor is filled or baptized with the Holy Spirit, and while so posséssed, speaks for God.

Properly understood and internalized by preacher and congregants, the "Word" becomes a powerful vehicle for transformation, because those involved believe it permits them to discern God's will. By knowing what God wants, they can know how to act. The community uses this important religious resource to gain new ways of understanding its problems, that is, it can place intractable problems into different contexts, so that, with God's help, they can find solutions. This ritual is a powerful source of empowerment because man's partner is none other than God. The church can create a framework for social action and for empowerment of a community by connecting the power of God and religion to the power to act within the political structure.

Such ritual occurs regularly in the Perrine community. In the following excerpt, Rev. Bennett "preaches the Word," the subject of which is a description of the transformation he believes will occur in the world if and when people become baptized with the Holy Spirit. Bennett calls this transformation "the renewing of the mind," which (as Bishop Watson, president of the West Perrine Christian Association, points out in the 
excerpt) is more profound than just a change of mind. The preachers explain that only a radical re-orientation will insure the future of the community, which they define in the widest possible terms, and in which they include all who wish to belong. The goal and results of such transformation include civic and political improvement in the lives of the community. The following is taken from a monthly West Perrine Christian Association meeting held on March $272001 .^{94}$

Rev. Bennett asked everyone to turn to Romans 12:1,2 and began to read,

I appeal to you therefore, brothers and sisters, by the mercies of God, to present your bodies as a living sacrifice, holy and acceptable to God, which is your spiritual worship. Do not be conformed to this world, but be transformed by the renewing of your minds, so that you may discern what is the will of God-what is good and acceptable and perfect.

As you turn your T.V. on every morning, and as you see things that's goin' on across this country, you can see that there's some troubled minds. There are a lot of trouble minded people here in this society. Amen, it's not safe to stick your children in schools. There's some troubled minds. It's not safe to go to the grocery stores. You don't know if you'll return home. There's some troubled minds. Troubled minds, I don't care where you're at, there's trouble. Between individuals that do things. It's not right. When you deal with a person with a troubled mind, there have to be a solution to a problem.

We don't need to look at, who's in the White House now; before they got there we still had troubled minds. No matter who's the governor, who's the mayor, we still have troubled minds. And we must deal with these individuals, and I'm going to tell you a secret now before I take my seat now. There's a solution to the problem. (Bishop Watson, standing behind the audience began to respond. The words in parenthesis reflect his responses: "All Right") Our children, that's behaving ...there's a solution for. ("All right") Husband who walk away from their wives and leave them there with three or four children, there's a solution to the problem ("Amen") Wives that walk up and down the streets at night, looking for that demon called crack, ("Yeah") there's a solution for the problem.

Apostle Paul, over here in Roman chapter 12, when he said, 'Look at here, I beseech you brethren,' In other words, Paul is saying, 'I beg you, brothers.' He's not talkin about the world now. He's not, brothers and ("Yeah") sisters in the Church House. ("Yeah") There're troubled minds in the Church house. ("Yeah") There're troubled minds in the Church House. ("Yeah" Others joined in) Church 
have troubled minds, you can imagine what the world is like. ("Alright") Paul standing here. He says, 'I beseechin you, brethren, by the mercy of God.

("Yeah") It wasn't because I was so good last night. It was because the goodness of God, and it was because of the mercy that got me here this morning. ("Yeah") It wasn't something that you did, that made you come here, but because of the mercy of God. ("Yeah") But it is I that seeking therefore but by the mercy of God that you present your body in living sacrifice.

When we take on Christ, when we take on Christ baptism, His belief, when we become Christians, we have to do things with our body and it would be a sometime, a sacrifice. ("Yeah") In other words, I cannot put all kind of chemicals in, and drugs and alcohol in this body, because this body is the Temple of the Holy Spirit. ("All right") Paul said, 'I want you to present your body a living sacrifice.' When you take on Christ, you sacrifice. I know when I was younger in my days, I used to, I grew up on pork. Amen, I ate pork chips, and pork rinds and pig feet. Everything else. But now, as you get older, you can't eat pork like you used to eat it. (People affirming vocally) Amen. It's what you call a sacrifice. I love ribs. When I see you all have a barbeque sale at a church I gotta come over and say 'I want ribs but I must present my body. If I take those ribs it will do harm to the body so give me chicken.'

But Paul say, look it here, Holy. Holy. But this the problem of society. No one want to live holy. (Audience is now doing the responding) I'm talking about living holy. And don't tell me you can't live holy in this society. You can live holy if you want to. Our children can live holy. The Bible say train up a child. We got to instill in our children that you can live holy. I don't care how you look at it. I don't care what temptation around you. You can live holy, you can live this life. And if you say, peer pressure....Look at Paul verse 2 say, he say, "Be not conform to this world." ("Amen")

The Church is in two worlds. ("All right") The church gets too worldly. It brings too many worldly things here. I'm from the old school. ("Yeah, All right") In the old school, when I went to church, I went to church in my church clothes. You know, there's something called church clothes. (Response) But now they come from the night clubs to the church house. ("All right") with the same clothes on. If, if, if, you don't have it, that's ok. Come as you are. ("Yeah") But when you have it, you should wear it ("Yeah") Now, you will never see a police officer in a nurses uniform. ("Yeah") You won't see that kind of stuff. Amen. So therefore, when we coming to God, we need to come to God as we come to God. ("Yeah") Not coming to a club somewhere.

I know you don't like this stuff. Paul said, "Be thou not conform to this world." We cannot bring worldly stuff in our churches because it's destroying our church. ("All right") If you look at the children now, they comin in any kind of way. ("Yeah") Now look, momma say, go put on your church clothes. Go put on your 
church shoes. ("Yeah") My church shoes are different than my school shoes ("All right") Amen. Now, now, you don't know what they wear. I was in one church, I won't call the church name, I was in one church, the preacher asked, why do you keep looking up? I said, I can't look down, because too much being exposed. Amen. Years ago, you go by a church mother, they say go get a hanky. Put a hanky on your leg. Do like that. And when you get out of church they say, "honey, that's a little bit short now." Now you can't say nothing to them. They're going to fight you. (Response)

....Paul say, "do not be conformed to this world." We can be transformed by renewing of our lives. Reverend, you said earlier before you got here, that there is a solution to our problem with our children. They need a renewed life. ("Yeah") There's a problem with our husbands walking out on our children. They need a renewed life. ("Yeah") There's a problem with a crack addict walking up and down the streets. They need a renewed life. ("Yeah") If you don't renew their life, it is yet dealing with the issues that they can have the problem.

Paul say, look, brother, I have to beg you all to do this for me, because this is very important, because if you don't do this you might have some problems. You might have some problems in the Church, you might have problems in the home, you might have problems in the school, you might have problems in the community. Because somebody don't want to renew their lives. Well, we can go on like this for years like this, but it's not working. We need to change up. Amen. If the Church is on the corner, been here for twenty five years, and still have the same twenty five members, something wrong. Somebody need to renew their mind.

We got to teach our parents, our teachers, our children, our community that God is the answer to our problems. OK how do you get around it? You don't have to call the 1-900 number, you don't have to call the psychic, you don't have to call and ask somebody to say read my palm. You got problems with the children? Look up this book, and put the book on them. Amen. Why do you think we have so much trouble in schools now. Because they removed a verbal prayer in schools. They got all kind of problems in school. Our children is not be educated because they refuse to look to the source of our solution. And God is the solution to the problem. How do you get around it. There's a solution to our problem. So once we do as Paul say, renewing your mind, once our mind get renewed....The help going to have to come from the Lord. If we don't do this, we're still going to have shooting at our schools. We're still going to have teen pregnancy in our schools. We still going to have drop out in our schools. It's a sad case in the State of Florida, $50 \%$ of high school children don't graduate. Something is wrong. Teenage mothers of the age of 12 and 13 having babies. It's a problem. We need to renew mind. As a solution to our problems. 
After Rev. Bennett finished, Bishop Watson took the podium and restated Bennett's Word, this time with Rev. Bennett's affirmations. He said, "Praise God. Present your body as a living sacrifice which is your reason for service. Be not conformed to this world; be you transformed." He added, "You can change your mind, but that's not gonna do it. But when you change it you'll be right back right where you used to be. But when you renew the mind, when you take the word of God into your mind, and I don't care who you is, you have to renew your mind. . "Then he summarized Bennett's words, drawing the contours of the Sacred Cosmos and placing himself and his fellow believers on the side of the higher authority, proclaiming, "There are two governments: White House government and Jesus is our government. And I hope is in Jesus." 


\section{NOTES}

${ }^{1}$ Rev. Walter Richardson, interview with author and Alex Stepick, tape recording, Perrine, Fla., 2 Nov. 2000; Rev. Walter Richardson, interview with author, tape recording, Perrine, Fla. 15 Jan. 2002; Tookes interview, Dec. 2001.

${ }^{2}$ In 1985 Ed Hanna founded the West Perrine Community Development Corporation (CDC) and continued his economic development projects through this organization.

${ }^{3}$ Rev. Richardson interview 2 Nov. 2000.

${ }^{4}$ Ibid.

${ }^{5}$ Shirley Green interview, March 2001.

${ }^{6}$ Ibid.

${ }^{7}$ Finkley interview, Feb. 2002.

${ }^{8}$ Ibid.

${ }^{9}$ Ibid.

${ }^{10}$ Rev. Richardson interview, Nov. 2000.

${ }^{11}$ Bishop Ingraham interview, May 2002.

${ }^{12}$ Ibid.

${ }^{13}$ Ibid.

${ }^{14}$ Hooghe and Stolle, Generating Social Capital, 11.

${ }^{15}$ Reno stressed the importance of geographic boundaries in maintaining communities. And, according to Reno, strong communities are the key to social improvement. She contrasted Perrine with Liberty City, the later which, although it had many black civic leaders, was hampered by the fact that the city/county line ran through its middle. One problem this posed was that it was difficult to coordinate several police forces. (Janet Reno, Dade County State Attorney and U.S. Attorney General, interview by author, 19 May 2005, Kendall, Florida).

${ }^{16}$ A report on the 1980 McDuffy riot concluded that although poverty, boredom, (caused by the lack of recreational facilities in black neighborhoods), and immigration, which caused the displacement of jobs and services from blacks may have been 
contributing factors to feelings of discontent among blacks, the number one cause of the riot was that blacks felt they were treated unjustly by the police and by the criminal justice system. The Perrine community, on the other hand, did not feel this immediate sense of injustice. Blacks had been on the police force in Perrine since the 1940's and there was a communal memory of fairness in dealings with whites (of course within the limits of socially imposed racism.) [Bruce Porter and Marvin Dunn, The Miami Riot of 1980 (Lexington, Mass: Lexington Books, 1984); Dunn, Black Miami, 245-267].

${ }^{17}$ Reno interview, May 2005.

${ }^{18}$ Richardson interview, January 2002.

${ }^{19}$ Reno commented about Rev. Richardson: "Walter Richardson understood immediately what was necessary. . . . He had identified the people who could make the community respond, pull the people together, keep them together despite the fact that they unravel. (Reno interview, May 2005).

${ }^{20}$ Richardson interview, 15 January, 2002. The following history concerning the formation of the NRT was taken from interviews with Rev. Richardson and Ron Tookes.

${ }^{21}$ Richardson interview, January 2002; Tookes interview, December 2001; Reno interview, May 2005.

${ }^{22}$ Ibid.

${ }^{23}$ Reno interview, May 2005.

${ }^{24}$ Tookes interview, December 2001.

${ }^{25}$ Ibid.

${ }^{26}$ Ibid.

${ }^{27}$ Ibid.

${ }^{28}$ Ibid.

${ }^{29}$ Ibid.

${ }^{30}$ Ibid.

${ }^{31}$ In discussing the various groups Tookes enlists as partners, it is important to note those he does not. One of these groups is the Hispanic faction. Tookes says that he does not try to solicit Hispanic businesses because there is a language barrier and that "they take care of their own." He explained that, with the exception of the NRT unit in Homestead that deals with the Mexican migrant workers, the NRTs were established to 
service the black community. Solicitation of white groups (meaning non-Hispanic whites, also referred to in Miami as "Anglos") and not Hispanics is another example of cooperation between two groups that have had a long history of conflict. But it is also part of a new political realignment in Miami Dade County that touches on a particularly painful sense of unfairness felt by African Americans. Since 1959, when the first large wave of Cuban immigrants began flooding Miami, blacks and Hispanics have competed for jobs, residential space and political power. Whereas in other southern cities, blacks had begun to achieve a significant level of political power as a result of the Civil Rights movement, in Miami they came in second behind the Cubans. In the following passage, Tookes points out another aspect of the cultural gap that separates blacks from Hispanics: attitudes about democracy. Tookes reveals a perception shared by many African Americans that Cubans, relative newcomers to America, disregard "American" rules and get away with it because of the political power they wield.(Ibid).

"Well these are Hispanics who are still upset about the Elian* scenario. The bottom line is, one thing that the Spanish must realize is, you know, there are rules, there are regulations, and there are laws. And as an Afro-American we understand that very clearly".

Tookes also does not work with Jamaican Churches, because he does not find as much need there as with African American churches. Jamaicans, he observes, have a different mentality than do African Americans. They do not want handouts, although if they are down and out, he says, they will look to the African American infrastructure to receive help. He admires Jamaicans for their hard working style and self reliance, an ethos he would like African Americans to adopt.

* In 2000, Elian Gonzalez, a Cuban child who survived a boat trip that killed his mother while fleeing Cuba, set off an international dispute as to whether he should remain in Miami with relatives, or be returned to Cuba to live with his father. Miami's Cuban community, (with the backing of Miami's Cuban born mayor, Alex Penelas) took the former position and tried to prevent (unsuccessfully) federal agents from sending the boy back to Cuba.

${ }^{32}$ Alexis de Tocqueville, Memoir on Pauperism, trans. Ivan R. Dee, Inc., introduction by Gertrude Himmelfarb. (Chicago: Ivan R. Dee, 1997), 59-61; David G. Green articulates two current policies, and offers that "We should aim, therefore, to base a policy of assisting the less fortunate, not on "rights," which are demands that other people be compelled to render assistance, but on duties, which reach within us all for our better nature." (David G. Green, "Community without Politics-A British View," in Peter L. Berger and Richard John Neuhaus, To Empower People: From State to Civil Society, [Washington D.C.: The AEI Press, 1996], 37).

${ }^{33} \mathrm{~A}$ Charrette, as defined by an anthropologist the M/AIA employed from the University of Florida, is a type of "operationalized crises:" According to this anthropologist, in the wake of a disaster, a community "is separated from normality in 
which status differences among people are reduced and behavior takes the form of communal helping activity. In effect, the first rescue and aid activities are often undertaken by victims themselves as everyone, regardless of status identity, is immersed in the common condition of suffering. People tend to behave in a selfless and altruistic fashion to help others." (Miami Chapter/American Institute of Architects West Perrine Charrette: AIA Florida/Design Assitance Team, "November 13 and 14, 1992).

${ }^{34}$ Tbid.

${ }^{35}$ The Charrette lists sixty one participants. In addition to the groups and individuals already mentioned others include, the residents of West Perrine, the Dade County Public Schools, Southwood PTSA, the Metro-Miami Action Plan, United Way, Headstart, Richmond/Perrine Optimist Club, the Beacon Council, Deering Hospital, five banks, the Goulds Coalition (the Gould's version of the West Perrine Christian Association), NAACP, and Dade County departments including police, Public Health Department, Health and Human Services, Water and Sewer, HRS, Planning Department, and the Parks and Recreation Department.

${ }^{36}$ The West Perrine Christian Association's contributions to the Charrette are listed in the final plan, a copy of which the author possesses. They include areas such as code enforcement (to clear overgrown lots, remove abandoned cars, raze or rahab boarded up buildings such as crack houses, remove illegal trash piles, demolish privately owned duplexes and apartment buildings not up to code), housing, commercial revitalization, health care, neighborhood municipal services (install sidewalks and fire hydrants, upgrade water sewer and drainage, upgrade street landscape) transportation, legal services, recreation, land use and development zoning, improve and increase facilities (maintaining HUD housing, build youth center), law enforcement, drug abuse, employment, education (including a community wide tutoring program through churches), non-profit groups, senior citizens, and business development.

${ }^{37}$ Beckford's history of Perrine is included in the West Perrine Charrette. A community song, titled, "A Caring, Sharing Community" Mrs. Beckford had written was included in the papers: "Perrine, I love You. Perrine, I love you - I love you in the spring! I love you in the fall - Perrine, I love you. Perrine, I love you. Perrine, I love you best of all."

${ }^{38}$ Gateways denote the extent of inclusion or exclusion of neighboring areas, and signify a community's desire to communicate their identity. (Ibid).

${ }^{39}$ Richardson interview, January 2002.

${ }^{40}$ Paterson, Social Capital, 54.

${ }^{41}$ Rev. Richardson interview, Nov. 2000.

${ }^{42}$ Shirley Green interview, 19 Oct. 2001. 
${ }^{43}$ Wayman Bannerman, assistant to Commissioner Dennis Moss, grew up in West Perrine. Bannerman, interview by author, tape recording, Miami, Fla., 9 Dec. 2001; Community meeting 19 March 2001; West Perrine Christian Association meeting, 27 March 2001.

${ }^{44}$ I was surprised by this receptivity when I attended a meeting of the West Perrine Christian Association for the stated purpose of conducting research. It was not till the meeting began that I realized that I was put on the agenda by president Bishop Watson and I found myself on the podium along with Commissioner Moss explaining my research project to the community. After this presentation, and at subsequent meetings that I attended, I was approached by members of the community who expressed interest in the history of their community that I had indicated I planned to write. Several people offered to let me interview them. One individual even inquired as to the potential resources FIU could bring to the community. (Town Meeting at Pentecostal Church of Our Lord and Savior Jesus Christ, Perrine, Florida, field notes by author, 19 March 2001; West Perrine Christian Association Meeting. 27 March 2001, Perrine Florida, partial tape recording; Shirley Green interview, April 2002.)

${ }^{45}$ Rev. Joseph Sumpter, pastor of St. Peters Missionary Baptist Church, Perrine, interview by author, 1 March 2001, Perrine, Florida.

${ }^{46}$ Shirley Green interview, March 2001.

${ }^{47}$ She said that recently there had been an increase in the number of black juveniles being transferred to the adult court system for prosecution. Florida law gives discretion to prosecutors to decide whether to transfer 16 and 17 year old juveniles to adult court to be prosecuted as adults. This is a significant decision, because the juvenile system prosecutions do not result in criminal convictions, while prosecutions in the adult system result not only in criminal convictions, but also in adult sanctions. She told them that 54 percent of the young people who are tried in the adult system are African American and Haitian and that 53 percent of young black males have convictions. Trying young people as adults, she said, meant that youth would stay in prison longer, they would lose their right to vote, thereby losing their ability to fulfill their civic responsibilities, they would lose opportunities for Federal grants for college, and they would be locked out of certain jobs such as teachers, government workers and security guards.

${ }^{48}$ West Perrine Christian Association Meeting, March 2001

${ }^{49}$ Ibid.

${ }^{50}$ Tbid.

${ }^{51}$ This point of view, part of a national discourse among certain segments of the black community alleging institutional racism, was expressed by prominent black 
minister, Bishop Victor Curry, of the mega-church, New Birth Missionary Baptist Church in North Miami. Bishop Curry is an outspoken political activist and former president of Miami's NAACP. Two notorious cases in south Florida involving black juveniles Lionel Tate and Nathaniel Brazil, who were tried as adults and sentenced to stiff sentences served as the catalysts for this discourse. Lionel Tate, was convicted of first degree murder and sentenced to life without parole, the youngest ever in the United States, after he fatally beat his 6-year old playmate in his home in 1999 . He was 12 years old at the time of the murder. Nathaniel Brazill was 13 in 2000 when he shot and killed a teacher at his middle school because he was angry at being sent home for throwing water balloons. He was convicted of second-degree murder and sentenced to 28 years in prison. Brazill has since completed his GED been moved to an adult correctional institution when he turned eighteen. Political pressure by black activists led to an early release of Tate after he served three years. But in May of 2005, while on probation, Tate was arrested, accused of stealing pizza from a pizza delivery man. ("Kids who Kill: What makes them do it?'Miami Herald July 30, 2005); Victor Curry of New Birth Missionary Baptist Church, and the president of the South Florida chapter of the NAACP, was active in efforts to reverse what he believed was discrimination of blacks in the juvenile justice system. (Field notes, Sunday morning church service at New Birth Missionary Baptist Church, North Miami, Florida, 21 January, 2001, by author).

${ }^{52}$ Shirley Green interview, March 2001.

${ }^{53}$ Alexander interview, as part of Finkley interview, February 2002.

${ }^{54}$ Ibid.

${ }^{55}$ Bishop Watson, interview by author, Perrine, Fla., 30 March 2001.

${ }^{56}$ West Perrine Christian Association meeting, $27 \mathrm{March}, 2001$. The full text will appear in chapter 9 of this section.

${ }^{57}$ Bishop Watson was referring to government officials from Washington who attended the meeting.

${ }^{58}$ Ibid.

${ }^{59}$ Lee Rainwater and William L. Yancey. The Moynihan Report and the Politics of Controversy: Including the full text of The Negro Family: The Case for National Action by Daniel Patrick Moynihan, (Cambridge, Massachusetts: The M.I.T. Press: 1967).

${ }^{60}$ Nathan Glazier, "Introduction," in E. Franklin Frazier, The Negro Family in the United States, (Chicago: University of Chicago Press: 1966). 
${ }^{61}$ Andrew Billingsly, Climbing Jacob's Ladder: The Enduring Legacy of AfricanAmerican Families (New York: Simon and Schuster, 1992). $\quad{ }^{62}$ Cited in Andrew Billingsly, Mighty Like a River: The Black Church and Social Reform. (New York, Oxford University Press, 1999, 87.

${ }^{63}$ Billingsly, Jacobs Ladder, 349.

${ }^{64}$ Green interview, March 2001.

${ }^{65}$ Sweet Home Missionary Baptist Church field notes, by author, Perrine, Fla., 20 Nov., 2000

${ }^{66}$ Rev. Gordon, interview by author and Christine Ho, tape recording, Perrine Fla., 20 Sept., 2001;

${ }^{67}$ Sweet Home field notes, 2 Oct., 2000.

${ }^{68}$ Richardson interview, November 2000

${ }^{69}$ The Pentecostal influence in music is widespread throughout black churches in general. In Perrine, the cross-over has been expedited by pastors, some of whom, like Rev. Richardson and Rev. Marshall (of Mount Moriah Missionary Baptist Church), were formally from Pentecostal Churches.

${ }^{70}$ St. Peters Missionary Baptist Church, field notes.

${ }^{71}$ Sweet Home Missionary Baptist Church Sunday service, Feb. 2001.

${ }^{72}$ Rev. Freeman said that youth at Sweet Home were introduced to some of these new forms of worship, like "ju jutsu worship" and "Hands of Praise" worship by attending an inter-denominational (and inter-racial) youth retreat. (Rev. Freeman said that most of the issues discussed at the retreat were so far removed from the experience of his young people that they could not relate to them: i.e. evolution. Freeman noted that black youth have so many more pressing needs that they must deal with before they can tackle what to them is a more abstract idea). [Interview with Rev. Freeman at South Florida Youth Ministries Meeting, 5 December 2000, Coral Park, Florida].

${ }^{73}$ At Perrine's other Jamaican church, Perrine New Testament Church of God, youth do not participate in running the church services. (Bishop Walden interview, October 2001).

${ }^{74}$ Sweet Home Youth Group meeting, October 2000; Although the training youth receive in church youth programs can ready them for civic leadership, this is not necessarily the intent of church youth directors. For example, Rev. Freeman, concerned that moral corruption in the church has turned away many men from church involvement, 
is interested in developing male leaders to bring men back to the church. (Freeman interview, April 2001).

${ }^{75}$ Community Church of Christ Written in HeavenYouth Group Observation, 06 November 2001, Perrine Florida; Marshall interview, November 2001.

${ }^{76}$ South Florida Youth Minister's Meeting, December 2000.

${ }^{77}$ Bible Class at Coral Reef High School. 24 October 2000, Richmond Heights, Florida.

${ }^{78}$ Sweet Home on Feb. 11, 2001 (field notes by author and Sarah Mahler, partial tape recording, Perrine, Fla.)

${ }^{79}$ Bishop Walden eventually became district supervisor of Perrine New Testament Church of God. Church of God is the oldest Pentecostal church in America, begun in 1886, with its headquarters in Cleveland, Tenn..

${ }^{80}$ Emmanuel Apostolic is a Jamaican organization with its headquarters in Kingston. There are forty Emmanuel Apostolic churches in Jamaica and three in South Florida. A general convocation is held in Kingston every November which a number of Perrine's congregants attend. Ministers receive training in seminaries in the United States which are considered better than seminaries in Jamaica.

${ }^{81} \mathrm{~A}$ third church, a racially mixed church with a white pastor, on the east side of U.S. 1, Perrine First Baptist Church, also includes many Jamaicans in its membership.

${ }^{82}$ The more relaxed dress also suggests more assimilation to American lifestyles. Religious practice on the Island tends toward a stricter dress-code: i.e. no jewelry, head coverings, dresses.

${ }^{83}$ Interview with Vanessa McCloud (pseud.), 5 December, 2002, Kendall.

${ }^{84}$ Emmanuel Apostolic Bible Study Class and Sunday morning worship service. 11 February, 2001, Perrine Florida.

${ }^{85}$ Richardson interview, 15 January 2002.

${ }^{86}$ In 2004, statistical information shows Jamaica as having one of the highest homicide rates in the world, with 62.6 people killed per 1000,000 population. Of the available statistics in the past decade, only Columbia and South Africa top 60. (Miami Herald, "Jamaicans are living in fear as homicide rate skyrocket: Jamaica is struggling to cope with drug crime and one of the highest homicide rates in the world," Thursday, July $7,2005)$.

${ }^{87}$ Rev. Gordon interview, September 2001. 
${ }^{88}$ Emmanuel Apostolic Sunday morning worship service, February 2001.

${ }^{89}$ Perrine New Testament Church of God 8:00AM Sunday worship service, field notes by author, Perrine, Fla., 25 April, 2001; Emmanuel Apostolic Sunday worship service and Bible Study, field notes by author, partial tape recording, Perrine, Fla., 11 Feb., 2001; Rev. Gordon, interview by author and Christine Ho, Perrine, Fla., 20 Sept. 2001; Bishop Walden, interview by author and Christine Ho, tape recording, Perrine, Fla..

${ }^{90}$ Fannie Mae Williams interview, March 2002.

${ }^{91}$ Sweet Home Missionary Baptist Church 7:45 Church Service, 24 September 2000, Perrine, Florida, partial tape recording.

${ }^{92}$ Sweet Home Missionary Baptist Church, 7:45 AM worship service, field notes by author, partial tape recording, Perrine, Fla., 24 Sept. 2000.

${ }^{93}$ Cheryl J. Sanders, Saints in Exile: The Holiness-Pentecostal Experience in African American Religion and Culture (New York: Oxford University Press, 1996), 70; Henry H. Mitchell, "Toward a Theology of Black Preaching," in African American Religious Studies: An Interdisciplinary Anthology, Gayraud Wilmore, ed. (Durham: Duke University Press, 1989). 362-364.

${ }^{94}$ West Perrine Christian Association meeting, field notes by author, Perrine, Fla., 27 March 2001. 


\section{New Rifts in the Community lead to a Decline in Civic Social Capital}

Towards the end of the 1990's morale began to decline in Perrine and along with it a loss in civic social capital. This was associated with the appearance of new rifts in the community that once again challenged Perrine's cohesion. After the Lawrence murder, when the initial flurry of activity by Perrine's newly formed coalition of churches produced rapid and immediately visible improvements to the community, including the closing of night clubs and package houses, the razing of crack houses, the routing out of a significant portion of the drug infrastructure, and an increased police presence, a sense of optimism pervaded among long-time residents. By the end of the decade community members began to feel discouraged by the seemingly intractability of problems that continued to plague Perrine - drugs, crime, urban decay, high school drop outs, teen pregnancies, joblessness, single family homes. Members, in fact, reported increased crime, the return of the drug dealers, and fears about leaving their homes. John Bruton of Mt. Moriah Baptist Church, seeing a connection between community disunity and the recent increase in crime, lamented, "I love the church. But it hurts me when I see the churches being not together here in this town. . . This is why we had to stop having (church) service at night over here. It's because of crime. . Y You don't know, even if you carry your kids to school, you don't know what going to happen. We're living in fear all the time."1 Richardson, although satisfied by many of the improvements in Perrine's physical environment, was disheartened by his failure to change the perspective of the community, still mired in what he called a 'generational curse:" "When we still have to celebrate kids celebrating high school because that's the 
first high school that's graduated, we should be celebrating someone graduating from college." As he passed kids waiting at a bus stop in Perrine one day, he wondered, "What are these kids going to do after, first of all, if, they graduate. What are they going to do five years from now. And what can we do to insure that a large percentage of them will be marginally successful."2

As community stability began to weaken, people began to look within the church itself as a source of Perrine's problems. Church corruption and moral failings among pastors were seen by many as evidence of a larger "spiritual" problem in the black community. Theological and other religious difference between churches took on greater importance as a zone of conflict emerged between different factions of the Perrine's church community. This chapter examines religious rifts that developed in Perrine during the 1990s, especially between the West Perrine Christian Association and the Richmond Heights group of leaders, showing how groups used religious symbols and ideologies to define their positions as they contended for political power.

First, a look at some of the theological differences that emerged between the West Perrine Christian Association and Rev. Richardson upon his ouster as president of this organization. Although Richardson's marches closed down many of the night clubs and package stores and routed out a significant portion of the drug culture, at least temporarily, after the Hurricane, Richardson was voted out of office of president of the Association based on the perception that he was not sufficiently focused on the spiritual aspect of the community. ${ }^{3}$ When the crisis that had led to the formation of the Association was no longer as immediate, the difference between Richardson's point of view and that of the other ministers in the Association became more noticeable. The 
pastors within the Christian Association, opposing Richardson, believed that, in order to find solutions to the problems in the community, it was necessary to strengthen the churches' spiritual foundation and that pastors needed rigorous work in their own spiritual lives to be effective leaders. These pastors believed that it was possible to become too focused on economic improvement, political activism and upward mobility, to the extent that the spiritual side is neglected.

Richardson, pushing Hanna's redevelopment plans and amassing political power for blacks in the wider arena, disagreed, "They felt that the organization wasn't spiritual enough. I said, but this is the essence of spirituality right here." ${ }^{\text {R }}$ Richardson felt that there was too much of a gap in the level of education, especially theological, between himself and the other pastors for them to work together effectively. Although he continued his membership in the Association, he became a less active member, focusing his efforts inwardly towards his church, with plans to build a large mega-complex including a church, school, senior citizen and drug rehabilitation center on land he purchased in Perrine, ${ }^{5}$ and outwardly into the wider political arena, where he attained greater exposure representing the "black community" on county wide committees and boards.

Richardson's ouster as president of the West Perrine Christian Association led to a restructuring of the political power arrangement of Perrine, with Richardson and the original Richmond Heights group of community leaders in one camp and the West Perrine Christian Association in the other. The pastors of the West Perrine Christian Association (although not all of them lived in Perrine, and some, in fact, lived in Richmond Heights) held more in common with the residents of Perrine than did 
Richardson, in matters of lifestyle, social values, educational levels, and certain forms of religious worship. Richardson's vast theological education, an asset in the wider community, was a liability to the West Perrine Christian Association. Although the two groups shared similar theological frameworks, the pastors in the Christian Association emphasized "living holy" as a ground for their political activities and Richardson, drawing from the thought of contemporary theologians, emphasized social change, responsibility and justice, and economic improvement as a spiritual virtue.

The Pentecostal-Holiness world-view would become an important feature of the West Perrine Christian Association's religio-political identity. Richardson, on the other hand, who grew up in a Pentecostal church, sought to identify as a Baptist to increase his exposure in the broader society. ${ }^{6}$ Cross-overs, from Pentecostal church beginnings to Baptist affiliations and vise versa were common-place among Perrine's pastors. The reasons varied: Rev. Marshall grew up in a Pentecostal church but a Baptist church offered him a job; ${ }^{7}$ Rev. Freeman, youth director at Sweet Home, grew up in the Pentecostal Church of God, but after he received his seminary training he felt Baptist congregations to be more receptive to his educational background; other ministers, like West Perrine Christian Association president Bishop Watson, grew up in a Baptist church but felt more of an ideological attraction to Pentecostal churches. Besides pastoring, he started a Pentecostal seminary in South Florida. ${ }^{8}$ Pastor Dolores Alexander, also brought up in a Baptist Church (Perrine's Mt. Sinai) joined a Pentecostal church. She was drawn to the strict codes of morality enforced by the Pentecostal church and to its transformative potential as a method to achieve much needed change in the church, the family, and the community. She eventually founded her own Pentecostal church in the 1970s in the 
neighboring Goulds community with her mother and husband, and an initial membership of twenty people. ${ }^{9}$

These cross-overs help to explain the Pentecostal influence in Perrine's churches, a phenomenon scholars refer to as neo-Pentecostalism. Most of Perrine's churches adopted Pentecostal practices (including an emphasis on the annointing of the Holy Spirit, laying on of hands, and speaking in tongues) into their worship services. Baptist minister Rev. Marshall joked that so many Pentecostal practices have come into his church that members "have a saying here that says this is Mt. Moriah Baptist Pentecostal Holiness Church."10 Other influences include music (discussed in an earlier chapter), emotional intensity of worship, and women in the pulpit. ${ }^{11}$

The attempt to formally integrate aspects of Pentecostal worship styles, the more egalitarian practices with regard to women, music, and free style of worship, led Rev. Sumpter's church, St. Peter's Missionary Baptist Church, to associate with the "Full Gospel Fellowship."12 This affiliation was a part of a movement in South Florida among Baptist Churches, including the large Bethel Full Gospel Ministry in Richmond Heights and for a time, the influential and politically active mega-church in north Miami, New Birth Baptist Church. ${ }^{13}$

Moral corruption, or "problems in the church house," as Rev. Bennett put it, has been considered a widespread problem by church-goers across all denominations in Perrine. Moral corruption has been seen as occurring in various forms. Some churches have been criticized for putting material needs before spiritual needs by using donations to buy or construct expensive buildings and to raise employee salaries while the poor went hungry. Church members and pastors were seen as violating a major tenet of 
Christianity, that of promoting unity, by letting personal disputes turn into power struggles that resulted in the establishment of "bastard churches." Congregants were accused of going through the motions of "being saved" without living moral Christian lives. ${ }^{14}$ The most serious criticism was one waged against some church leaders, that they routinely engaged in inappropriate sexual behavior and thereby compromised their moral authority. As Pastor Dolores Alexander stated it, inappropriate sexual behavior was so commonplace in churches that women congregants found that "it was a popular thing to be entertained privately by the pastor." ${ }^{15}$ Perrine resident Emma Ferguson (pseud.), disillusioned by moral corruption in the various churches she belonged to over the years, is unaffiliated today: "The church today is all about the dollar," she says. Unimpressed by the shouting and by congregants' claims of receiving the Holy Spirit, she asks, "What is the purpose of getting up and shouting if the next day you're being with somebody else's wife or treating someone badly at work?"16

In a zone of conflict that pitted the Pentecostal/Holiness faction of Perrine's community against the "worldly" faction, the classic Pentecostal/Baptist dispute was reactivated by the Pentecostal group to argue that moral failings predominated in Baptist churches due to liberal, rather than literal interpretations of Scripture, ${ }^{17}$ their embrace of secular values, and their tendency to associate with higher social classes. Some Pentecostals in Perrine identify with the lower economic strata, promoting the view that upwardly mobile aspirations of certain churches, with their drive for economic and social advancement, erodes the essential elements of Christian spirituality by allowing the intrusion of materialistic influences. Pentecostal church member Shirley Green explains the latter point, drawing from the origins of Pentecostalism: "Jesus selected his apostles, 
his initial followers from the ignorant. Fishermen, people that really had no skills, very little learning. He wanted them to have total faith in him and not be tainted in any other philosophies. In fact, his little group was so determined to keep their group as they were. They were upset with Jesus when he asked to visit Matthew who was a tax collector. His apostles were against him. Because they say, you really shouldn't be with him because he's not one of us. He's of a higher class than we are."18

In some ways, the rift in Perrine mirrors a social divide some social historians refer to as a "culture war." Gertrude Himmelfarb, for one, refers to this divide as an "ethics gap" that she says runs through society, dividing it not by race, religion, ethnicity, class, party and sex, but by moral and cultural values. ${ }^{19}$ Dolores Alexander's "War of Religion" portrayal is another way of stating this schism. This conflict is played out in Perrine with the West Perrine Christian Association's criticism of the Richmond Heights group. Members of the West Perrine Christian Association, for example, were offended by an extravagant Martin Luther King Parade in Perrine, organized by Ed Hanna that included scantily clad cheerleaders from FAMU, a black college in Tallahassee. They believed that Hanna's group was bringing in negative influences of "secular society" by financing an expensive event when home-grown talent would have well served the purpose, and that the explicitly sexual dancing of the FAMU cheerleaders was antithetical to the moral values held by the community. As Pastor Dolores Alexander (not a member of this organization) complained, "And then they pay all this money to get them to come just to show our kids their crotches. We have enough talent in Perrine to put on our own program. We don't have to go out looking, payin' nobody ten thousand dollars to get them to come sing to us for one hour."20 Pointing to lapses in sexual 
morality by prominent ministers and community leaders, an emphasis on material indulgences, and general corruption in the churches, some in the Pentecostal/Holiness faction of the West Perrine community decried what they believed to be the negative influences of "secular" society on Perrine's well-being.

Factionalism also plagued the Pentecostal/Holiness sector of Perrine, weakening its civic social capital base. Rev. Sumpter, speaking for many in the community who decried the divisions among Perrine's churches, expressed the need for community unity: "We have to have togetherness. And once we have togetherness, that's where the power's going to come from." While president of the West Perrine Christian Association, Sumpter tried a theological remedy, taken from Corinthians I, to unify churches in Perrine. Yet the lack of cohesion between churches with seemingly similar goals prevented him from implementing a program to coordinate services offered by individual churches without duplication, where labor could be divided and programs, like a community run day care center and after-school tutoring program, could be expanded. According to Rev. Sumpter the plan failed because of a "too many big I's and little you's" mentality among pastors that prevented power-sharing. ${ }^{21}$ Rev. Sumpter also attempted to foster togetherness by inviting churches to St. Peters to worship together, in a common practice among churches called fellowshipping, but in this, too, he was unsuccessful, as ministers could not agree on worship practices. Rev. Sumpter saw his failure to achieve togetherness as a failure to gain power for the community. ${ }^{22}$

The black community, has long looked to their church leaders to find solutions to their problems. According to Pastor Dolores Alexander, people look to their pastors as saviors, but that invariably they are disappointed: "We're used to having a Moses or a 
Dr. Martin Luther King, or a Richardson, or somebody, but most times what usually happens is, you put your faith in that person, and then the next thing you realize that as the connector between the church and the government, and the next thing you know, you're sold out. . . You find out that they sold out for the money, or they sell out the people, or they join in with the people that you tryin' to help. And they start doing the same thing the people were doing that you're trying to help." Alexander asks whether pastors, if they are part of the problem, can be part of the solution: "Everybody's drinking, everybody's fornicating, everybody's committing adultery. Not everybody is. But then, the mentality is, everybody doing it so now the mentality is it's acceptable. So if the preacher is committing adultery, who's going to stop the people?" In other words, can the church provide the remedy for an illness by which it is also afflicted? ${ }^{23}$

Dolores calls on pastors to change themselves so they can lead the community:

"The church can be a powerful vehicle for change. You do need leaders. You need credible leaders. Leaders who can say, I believe in family. You may not find one person in Perrine who has not ever thought about being divorced, thought about fornication. But can you find somebody who stands up there and says, I'm like you, I have the same temptations, but I don't yield to every temptation that comes along? I fight like the devil? ... Folks want to know, can anybody stop, has anybody? You have to have the courage to say, look I was an adulterous. [sic] I'm not an adulterous [sic] now. I used to do this. But I've grown. I don't do that any more."24

The call for reform, be it internal, as relates to one's individual religious institution, or external, in connection with the larger society, is one of the motivating forces behind the proliferation of new forms of American Protestant religion. This 
phenomenon is evident in the black community of Perrine. From 1919, when Robert Bruce Ingraham formed the first Holiness church in Perrine because he could not countenance the moral behavior of his fellow congregants at Pine Grovers Church, to the present, new churches have originated from a sense of mission their founders have had to restore the central teachings of Christianity, however understood, to the church. This impulse has led to the widespread embrace by Perrine's community members of religious practices with transformative potential and attests to the community's understanding that civic improvement necessitates spiritual self-improvement.

Community members across all denominations, looking today, as they have historically, to their churches to provide solutions to their problems, see a church that in many ways mirrors the problems it is trying to correct. For Gunner Myrdal's observation about the black church and black community over sixty years ago is as true today as it was when he made then: "The Negro Church fundamentally is an expression of the Negro Community." Dolores Alexander re-articulates this view at the turn of the twentyfirst century when she says, "The family is the small church." She continues, suggesting that what is wrong in the church is wrong in the family and vise versa: "And you just take the church. You just take it with you when you go. So whatever is missing here, I submit that it is missing in the church as well. Because it's the same people. We don't change personalities. We don't change our motive just because we went to church.",25

The call for a return to core Christian teachings in order to restore the values on which Perrine's community depends, runs across all denominations. As long-time member of one of Perrine's historic mainline churches, John Bruton declares, "Charity start at home. And we doesn't have charity. We're teaching it, but we're not putting it 
into practice. And we leave our churches, and we pour hate in our children's heart. And they take to the streets. And that's what it's all about. It's not going to start until we start getting sincerity in our religion and we're not. We're just putting on a show. That's all. We don't care for one another.,26

The 1990s saw a decline in Perrine's civic social capital. Lack of community cohesion was evidenced by increased factionalism and seemingly irreconcilable rifts. Weakly defined zones of conflict developed between different factions of Perrine's church community with theological and class differences assuming a greater importance. But unlike the Lawrence murder that had served to galvanize the community a decade earlier, there has been no key event, one issue, or central leader that has been able to bring together the disparate factions. Looking at the black church itself as a source of Perrine's problems, community members have correctly recognized that church corruption, moral failings among pastors, and power struggles among church leaders have led to an erosion of the moral authority of the black church and, as John Bruton pointed out, have contributed to a decline in important features of Protestant religious practice, like "car[ing] for one another," that contribute to increasing the "radius of trust" between community members. 


\section{NOTES}

${ }^{1}$ Bruton interview, 28 November, 2001.

${ }^{2}$ Richardson interview, 15 January, 2002.

${ }^{3}$ Richardson interview, November, 2000.

${ }^{4}$ Richardson interview 2 November, 2000.

${ }^{5}$ As of this writing, the physical plans for this enterprise have not progressed beyond the ground-breaking stage.

${ }^{6}$ Richardson thought "the message of Christianity was more universal than what I was hearing at my dad's church," a church he found too "isolated" and "exclusionary"a forum for the vision and mission he believed he was given. He brought certain "charismatic" elements from his Pentecostal background to the Sweet Home worship service, including an excitement, especially in music (he introduced the drums and guitar to Sweet Home), more free movement in the pulpit, a more informal approach to worship, and women in the pulpit. (Richardson interview, 2 November 2000).

${ }^{7}$ Marshall said there was less opportunity to preach at his Pentecostal church: "I remember one time I turned around to the preacher who was my pastor and said, "the Lord has called me to preach. He said, all right, I'll let you know when the Lord tell me." He enjoyed the freer lifestyle the Baptist church allowed their members: "At that time, the Pentecostal churches that I knew, they really shot from the hip and they were very conservative and so strict and you couldn't have fun, and you couldn't go to the movies, you can't wear earrings. And the Baptist folks say, hey, go on to the movies, you know." (Marshall interview, 16 November, 2001).

${ }^{8}$ According to Bishop Watson, he was led to Perrine (in 1992) by a vision from God, revealed to him in a dream. The description and location of the church he bought in Perrine was shown to him in his dream. (Watson interview, $30 \mathrm{March}, 2001$ ).

${ }^{9}$ Alexander does not see much of a difference between Baptists and Pentecostals besides the difference in their worship services, the Baptist service being more formal in structure. Growing up in a Baptist Church she did not relate to sermons, all taken from the Old Testament, because they seemed to endorse the status quo. She said she never heard the Gospel, which she believes is the key teaching instructing personal and social change, preached. (Alexander interview 11 April 2002).

${ }^{10}$ Rev. Marshall interview, 16 November 2001.

${ }^{11}$ The issue of what role women are to play in the church has been the subject of doctrinal disputes within the various Baptist associations but the autonomous nature of 
Baptist congregations ultimately leaves the decision up to the individual pastors. In general, women assume more visible roles in Pentecostal churches. But as a practical issue, the dearth of men in churches as compared with women, has opened the way for more women to assume roles, formerly closed to them.

${ }^{12}$ This church, along with Sweet Home, is the most socially active churches in Perrine. St. Peters runs a food bank and successful soup kitchen on Fridays, bringing senior citizens to St. Peters for a sermon and a meal. Rev. Sumpter works closely with Ron Tookes, is active as a member of the West Perrine Christian Association (he was its second president) and has close connections to many of Perrine's citizens on a grassroots level. St. Peters originated as a Bahamian Church. (Rev. Sumpter interview, 1 March 2001; Rev. Sumpter interview, 12 Feb. 2002; Fannie Mae and Sinclair Williams interview, 13 March 2002).

${ }^{13}$ According to Rev. Freeman, The Full Gospel Fellowship was begun by Bishop Paul Morton (date of origin unknown). Morton, originally from the Pentecostal Church, Church of God in Christ, combined some of the structure of the Baptist service, and certain worship styles of the Pentecostal Church. (Freeman interview, 3 April, 2001). Political activist Bishop Curry, of New Birth, had been the president of the Miami chapter of the NAACP. He had ties to Rev. Richardson, who invited him on occasion to speak at Sweet Home. (Ibid).

${ }^{14} \mathrm{John}$ Bruton of Mt. Moriah Baptist Church explains this view, saying: "a lot of peoples are say that they know Christ, they been born again, this and that, and they hate someone. That's telling me that you haven't been born again. Because you say one thing and I'm seeing something else.... But one thing I do know, I do know that your life style will tell on you. And that's all this. And emotion and talking in tongue and all that you been born again. Because that's a practice." (John Bruton interview 28 Nov., 2001), Emma Ferguson (pseud.) interview, 5 December, 2002; Vanessa McCloud interview, 5 December, 2002.

${ }^{15}$ Alexander interview 11 April, 2002.

${ }^{16}$ Ferguson was born to Bahamian parents in Key West in1954 and moved to Perrine in 1959 with her family. Her family had belonged to an Episcopal Church in Key West but because there was no Episcopal Church in Perrine, her family jointed the Pentecostal Church of God. Ferguson relates that in the 1960s women had their hair rough dried, their arms were covered, and they wore no earrings. Now, she says, "you don't see these things any more in the church." She tried out other churches but eventually withdrew from church involvement. Unaffiliated, Emma nevertheless is civically active in Perrine. Interested in preserving Perrine's history, she was, at the time of this interview, part of a group in Perrine that was organizing a hundred year anniversary of Perrine, with plans to include, among other things, a tour to Indian Key where Dr. Perrine was murdered by Indians in (1840). Among other projects she has undertaken is the running of a non-profit organization that brings cultural arts to children 
in Perrine. (Emma Ferguson interview, 5 December, 2002); Another example of an unaffiliated, but civically active women in Perrine is Ruth Page, a long-time political activist on the local, county-wide, and even national level. Page's picture had been painted as part of a mural on one of the buildings in the Perrine Gardens Public Housing Project. (The mural was later painted over). She has been described as a "one woman church," riding the streets of Perrine on her oversized tricycle and preaching. (Vester Jefferson, Dolores Alexander, and Archie Finkley intervew by author, 25 March 2002, Perrine, Florida)

${ }^{17}$ Traditional Holiness/Pentecostal churches follow what they consider a literal interpretation of Scripture. They emphasize spirit baptism and holiness ("living holy" as Rev. Bennett referred to it). Members are monitored for their moral conduct and for their service to the community, including visiting the old and sick in hospitals and nursing homes and distributing food to the poor. Providing services are linked to the biblical command to evangelize.

${ }^{18}$ Shirley Green interview, 28 March, 2001.

${ }^{19}$ Gertrude Himmelfarb, "Democratic Remedies for Democratic Disorders." 14 December, 2004 http://www.thepublicinterest.com/notable/articles8.html.

${ }^{20}$ Alexander interview, 11 April 2002.

${ }^{21}$ Rev. Sumpter modeled his plan on the Five-Fold Ministry idea, which forms part of Pentecostal doctrine. It is taken from Corinthians I, in which the apostle Paul gives advise to a troubled church, beset by divisions, sexual immorality, and chaos in the worship service. The Five-Fold Ministry is a prescription for unity, whereby disparate members can work together, each according to his or her talents, to form a single unified body.

${ }^{22}$ Sumpter interview, 12 Feb. 2002; Shirley Green offers a different opinion. She sees differences between churches as positive element and believes that variety among Pentecostal churches, and their ability to "divide and spread," is the source of their strength. Green interview, March 2001.

${ }^{23}$ Alexander, interview April 2002.

${ }^{24}$ Green interview, March 2001.

${ }^{25}$ Alexander interview, April 2002.

${ }^{26} \mathrm{John}$ Bruton interview 28 Nov., 2001. (Member of Mt. Moriah Bapist Church). 


\section{Perrine's Civic Social Capital Extends to National Policy}

One of the more successful returns on Perrine's churches' investment of civic social capital,was Perrine's NRT initiative, initiated by Janet Reno and headed by police officer Ron Tookes. The NRT, begun as an experiment to lower crime, would have national ramifications. When President Bill Clinton appointed Janet Reno United States Attorney General in 1993, her agenda as the nation's leading law enforcement figure was shaped by her experiences in West Perrine. Using Perrine's NRT model as an example of successful synergism between community and government, Reno encouraged law enforcement agencies from around the country to adopt similar models according to their particular local needs, and she invited Ron Tookes and other members of South Dade's NRTs to the Department of Justice in Washington D.C. to explain to a nation-wide assembly of government officials how their program worked.

Reno's office assisted Clinton in drafting his Welfare Reform Bill which was passed by Congress in 1996 as the Personal Responsibility and Work Opportunity Reconciliation Act, otherwise known as the Welfare Reform Act. This act, considered by many across the political spectrum to be the most significant law passed in recent decades has marked a change in public opinion concerning the relationship between poverty, personal income and work. It embodies a belief that low income individuals and families are better served in the long run by working than by receiving cash assistance; in other words, work, and not public subsidies in the form of welfare checks will reverse the "generational curse" of poverty and hopelessness. 
In 1996 a "Charitable Choice" section was added to the Welfare Reform Act, encouraging collaboration between government and religious institutions. The reasoning behind this act was a belief that the grass-roots nature of faith-based workers place them in a better position to assist poor people in becoming self-sufficient through stable employment, to provide them with the intense, personally tailored help they need, and to transform distressed neighborhoods. The law prohibits public officials from discriminating against religious social-service providers that seek to compete for government contracts, and it protects the religious integrity and character of faith-based organizations. These ideas were taken up by President George W. Bush who, in one of his first major initiatives, established the Office of Faith-Based and Community Initiatives in an effort to overcome some of the bureaucratic obstacles to the participation of faith-based organizations. The Clinton and Bush administrations, in establishing these public policies and initiatives that facilitated collaboration between government and religious and non-religious institutions, gave voice to what Ron Tookes expressed earlier in this case study, that "government can not do it alone. Government needed community input. It needed input from the clergy, from the church."

The multi-agency/multi-institutional approach that knits together governmental agencies, businesses and religious institutions and harnesses the civic social capital of communities has been adopted by major cities across America. Welfare reform, including Charitable Choice, has engendered a growing tide of government-faith community collaboration. As of 2002, new cooperative relationships between government and religious organizations, involving either financial or formal non-financial collaborations, were operating (or in the design phase) in at least thirty-two states. ${ }^{2}$ 
Collaboration between government and communities has been particularly evident in the area of crime prevention. Variations on Ron Tookes' faith-based model for crime prevention among youth have been adopted in other areas of the country. Probably one of the best known and effective initiatives is Boston's Ten Point Coalition, begun by the Rev. Eugene Rivers III (of the Azusa Christian Community, a Pentecostal church affiliated with the Church of God in Christ), the Rev. Ray Hammond (of Bethel AME Church) and Rev. Jeffrey Brown (of Union Baptist Church) in the early 1990s. ${ }^{3}$ Its beginnings share similarities to the formation of the West Perrine Christian Association: in the late 1980s, a group of black inner-city ministers in Boston organized themselves around a plan for cutting juvenile violence, reclaiming parks and sidewalks, educating atrisk children, promoting local economic development, strengthening families, and resurrecting the communal life of their jobless drug-and crime-infested neighborhoods. Although this group drew support from Boston's Catholic Church and several local synagogues, the full advantage of this important source of civic social capital was not realized because the ministers lacked cohesion due to internal bickering and power struggles. A tragic event in May 1992 involving a shootout and multiple stabbing of a young man attending a funeral service for a youth murdered in a drive-by shooting by a rival gang member galvanized the clergy to take action by forming the Ten Point Coalition, a group of some forty churches. The group called on churches to participate with a publication of a "Ten-Point Proposal for Citywide Mobilization to Combat the Material and Spiritual Sources of Black-on-Black Violence" 4

According to Rivers, the Ten Point model was derived from conversations with a young crack dealer who "recruited" members of the Azusa Christian Community in 1988 
and then explained what kind of outreach was needed to curb crime among youth. The dealer told them, "I deal in drugs because there was no adult in my life to tell me that what I was doing was wrong; I don't have a father figure who functions as a sign of love, authority and discipleship." Additional insight came after Rivers, frustrated by repeatedly having his inner-city row house sprayed with bullets, asked a major local drug dealer, '"Man, why did we lose you? Why are we losing other kids now?' He stares us in the eye and says, 'I'm there, you're not. When the kids go to school, I'm there, you're not. When the boy goes for a loaf of bread or wants a pair of sneakers or just somebody older to talk to or feel safe and strong around, I'm there, you're not. I'm there, you're not; I win, you lose.",

Another conversation with a young heroin dealer showed Rivers that the achievements of the civil rights era could not speak to the spiritual decay that plagued the young black men who were abandoned by the church, "predators amongst their own people." This heroin dealer prompted Rivers to ask, "Why, if we did all these works in God's name, did we never talk about God? Why, if we were following Jesus' example, did we never mention Jesus by name?" Rivers realized that having grown up with the civil rights movement, he believed that a helping hand was all that was needed, that talk of rights and justice would resonate with these young people, enough to bring out their religious faith. Not wanted to be "religiously offensive," he hid his own religious faith. Rivers writes:

We realized the hard way, as the people of Dorchester had, that secular institutions could never work in these forgotten pockets of despair. We realized that therapeutic institutions such as government, foundations, public schools, and the whole panoply of non-faith-centered self-help outfits could not speak to the depth of psychic and moral decay that plagued our inner cities. The black 
leadership of the civil rights era had no answers for the generation born into chaotic, broken families, who would be lured by the culture of violence to gangs and drugs and destruction. The language of civil rights was ineffectual in battling contemporary moral issues. The language that worked was the familiar, transformative language of the Gospel. We found that only by offering to feed the souls of these children could we turn a generation around and bring hope back to our communities. ${ }^{6}$

The first two of the Ten Points involve the establishment of church cluster collaborations that sponsor Adopt-A-Gang programs to organize and galvanize youth who are in gangs, and the commissioning of missionaries to advocate for black and Latino juveniles in the court, working closely with probation and law enforcement officers. One result of these efforts has been a change in the way the police (and other elements of the criminal justice system) and Boston's inner city community relate to each other. (The close alliance the Coalition has with Boston's Catholic Church has helped to reduce hostile and highly confrontational relationships been blacks and police. The late archbishop of Boston, Cardinal Bernard Law, played a major role by influencing a largely Irish Catholic police force to back off from some of their more aggressive techniques). A second result has been a sharp decline in homicide rates compared with other cities in the country. For the 29 month period ending in January 1998, Boston had no teenage homicide victims. During 1999 there were only four. ${ }^{7}$

The Ten-Point concept has grown into a national model. As of September 2000, Rivers and Brown, as co-chairs of the national Ten Point Leadership Foundation, have met with local officials and ministers in as many as thirty-five cities from Atlanta to Los Angeles to share their experiences in reducing youth violence. ${ }^{8}$ As communities develop better working relationships with the police, they become partners and not adversaries in 
fighting crime. Even if the process is slow, churches can provide alternative communities for gang members.

Nationwide, law enforcement strategies have begun to change. Rather than the widely used "get tough" system, innovative approaches are tried, such as Ron Tookes' "tough love" method of sitting in a dope hole to convince drug dealers to stop selling drugs and go to church. As Tookes had learned in Perrine, others, like Los Angeles police chief Bratton, also came to the realization that the get-tough approach used against Los Angeles' gangs in the 1990s was ineffective. In 2002, when crime statistics shot up after a wave of gang members who had been sent to jail in the early 1990 s were suddenly released and hit the streets, local law enforcement officials began to rethink their approach. Bratton warned other cities not to rely exclusively on law enforcement as Los Angeles did in the 1990s, saying, "We think of prison as punishment, but in many instances we're just reinforcing their loyalty to the gang. ... To them prison is like going to finishing school." In 2003 the city's police department, realizing the importance of community input in changing behavior of its youth, created Community Impact Action Teams that brought together local, state, and federal law enforcement agencies (including probation and parole officers and city and state prosecutors), representatives of local school districts, citizen watchdog groups and clergy. The following year crime was down $14 \%$ from the previous year. ${ }^{9}$

The result of joint efforts between governmental agencies and communities has resulted in changing political alliances among a segment of black churches nationwide, challenging the close historical ties the black church has had to the Democratic Party. Some black ministers, like Bishop Harry R. Jackson Jr. who leads a congregation of 
3,000 at Hope Christian Church in Lanham, Md., regularly meets with white evangelical Christians to plot a strategy to "protect American family values" in an effort to address the "moral crises in the black community." Jackson, a Democrat who voted for Bush, argues that blacks have been "duped" by the liberal black leadership: "The Congressional Black Caucus hasn't made any changes. All they do is give a bunch of excuses," he says. "We need a little tough love instead of all this crying racism and saying 'the man is against you.' It's too simplistic." Rev. Eugene Rivers is another Democrat who voted for Bush. Commenting on how his grass-roots experience in crime prevention has challenged his assumptions and led to new alliances, he writes, "I have been on the left side of most things for thirty years, and I could have used that position to come to quick and easy conclusions. However, once I was forced to deal with criminal activity at the street level, all of my left-leaning rhetoric collapsed." $" 10$

Besides indicating a shift in public opinion about the relationship between poverty, personal income, and work, the Welfare Reform Act is also significant because it indicates a shift away from Federal control of welfare programs to state control. The law is based on the idea that states best know how to tailor programs to their local economies, employers, public agencies, and economically troubled families, and that spiritual assistance offered by churches on a grass-roots level is often the key to helping someone move out of poverty. ${ }^{11}$ The effect of this law has been to narrow the gap between government and black civic institutions, allowing greater participation by black institutions in the political system. When partnerships are formed to achieve similar goals, commonalities are discovered and the radius of trust is extended beyond one's own group. Thus is civic social capital created. 


\section{NOTES}

${ }^{1}$ National disillusionment with America's welfare system can be dated to the 1965 publication of "The Negro Family," (known as the Moynihan Report), which, as mentioned in an previous chapter, suggested that the breakdown of family ties among blacks and not joblessness and poverty is the leading contributor to the many social ills that plague ghetto life. Since then, a growing body of scholarship has documented the rise of a large underclass gravely dependent on the existing welfare system, turning the debate as to poverty's causes from being primarily financial to one of behavior. (Amy L. Sherman, "Get with the Program; Mainline Churches Drag their Feet on Welfare Reform," The American Enterprise v. 8 [January/February 1997], 65-8); Since the passage of the Welfare Reform Bill, there has been a growing body of research on community service by congregations, particularly those that are engaged in "development-oriented" programs that seek to address the underlying causes of persistent poverty. Amy Sherman has a detailed bibliography of this body of scholarship in chapter two of her book: (Sherman, Amy L, Reinvigorating Faith in Communities, [Fishers, IN: Hudson Institute, 2002]).

${ }^{2}$ Amy L. Sherman, Reinvigorating Faith in Communities (Fishers, IN: Hudson Institute, 2002), 72.

${ }^{3}$ Janet Reno considers Boston in the 1990s to be the best example of successful synergy between the government and the black community. She attributes Boston's success to an excellent police chief, mayor, domestic violence court, public health resources through the Boston Hospitals, and the work of the Ten Point Coalition. (Reno interview, May 2005).

${ }^{4}$ John J. DiLulio, Jr., The Lord's Work: The Church and Civil Society, in Community Works: The Revival of Civil Society in America, edited by E. J. Dionne Jr. (Washington D.C.: The Brookings Institution, 1998), 50-51; Jenny Berrien and Christopher Winshipp. "Should We Have Faith in the Churches? The Ten-Point Coalition's Effect on Boston's youth Violence." 2 September, 2005 http://www.wjh.harvard.edu/soc/faculty/Winship/Winshipp1.

${ }^{5}$ George M. Anderson, “Addressing Youth Crime: An Interview with Eugene F. Rivers," 4 September, 2005. http://www.americamagazine,org/gettext.cfn?article; DiLulio, The Lord's Work, 51.

"High-Octane Faith and Civil Society," Edited by E. J. Dionne Jr. Community Works: The Revival of Civil Society in America (Washington D.C.: The Brookings Institution, 1998) 59-63.

${ }^{7}$ Anderson, "Addressing Youth Crime;" See Berrien and Winshipp, "Should we have Faith in the Churches?," a study supported by a grant from the Smith Richardson 
Foundation for their analysis on the aspects of the Ten-Point Coalition that contributed to the drop in homicide rates in Boston, compared with other cities.

${ }^{8}$ Their goal is to build new grassroots leadership in forty of the worst inner city neighborhoods in the United States by the year 2006. Rivers calls for a radical reformation within the black church to restore its moral authority. In order to develop leaders, he maintains, corruption must be rooted out, the church must look for better ways to meet the spiritual, cultural, and economic needs of a growing number of black men, and the church must become more unified to increase its power to call for and press for changes in public policy. Rivers calls for a new generation of black church leadership to develop strategic alliances with progressive wings of the white evangelical and Roman Catholic traditions. (Rivers appreciates the Catholic organizational structure as more effective in placing "troops" in the field than the Protestants, who are more sectarian). [Rev. Eugene F. III. "Challenge from Within: A Call to Address the Black Church Leadership." (2001) 4 September, 2005. http://www.tgsrm.org/Church\%20Leadership\%20Crisis.html.]; Anderson, "Addressing Youth Crime."

${ }^{9}$ Los Angeles has been dealing with transnational gangs including the Mara Salvatrucha (of Salvadoran origin) as well as homegrown gangs, such as the infamous Crips and Bloods. [Ana Arana, "How the Street Gangs Took Central America." Foreign Affairs (May/June 2005), 98-110.

${ }^{10}$ Eugene F. Rivers III, Effectiveness over Ideology: Church-Based Partnerships in Crime Prevention, edited by E. J. Dionne, Jr. and Ming Hsu Chen, Sacred Places, Civic Purposes: Should Government Help Faith-Based Charity? (Washington D.C: The Brookings Institution, 2001).

${ }^{11}$ Ryan Streeter, "Charitable Choice as Historical Phenomenon and Future Reality," Welfare Policy Center, Hudson Institute (Jan 1, 2001) http://www. WelfareReformer.org. 


\section{Conclusion}

Over the past two decades social scientists have given considerable scholarly attention to the ideas of social capital and civil society. These ideas have become increasingly important in public debates concerning a wide range of issues from those on the domestic front to those of foreign policy. Discussions in many Western societies focus on the importance of a healthy civil society to the proper functioning of democratic societies. Some debated topics touch on similar themes to those in this study, including, for example, the rebuilding of communities as a key to alleviating urban problems (such as crime, inner-city blight, and poverty) and associated social ills (such as drug and alcohol addiction, teen pregnancies, mental illness, domestic abuse) and the role of religion in this process. Other topics, related, but not part of this analysis, concern whether democratic political systems can be prescribed for societies within totalitarian political systems, for example, in Eastern Europe and most recently in the Middle East. The underlying theme of these various discussions concerns the generation of civic social capital, in other words, how political participation can be increased and cooperation be encouraged between groups with seemingly opposing interests and differing norms and values. This thesis, by describing and analyzing the role of religion in the generation of civic social capital in the black community of Perrine, Florida, adds to this discussion and debate.

What is significant about this case study is that it examines one community over the course of a hundred years, a period marked by large-scale events (such as the formal inclusion of blacks into America's political system) and changes (including extensive 
demographic changes) with which it was forced to deal. Throughout this time, the community of Perrine remained intact, with a core group of Perrine's citizens retaining a strong sense of community and a commitment to passing on its values to subsequent generations. The longitudinal approach of this study has allowed us to view the process of civic social capital formation in a variety of contexts and to observe the effects of some of the external social processes on Perrine's civic capital production and deterioration.

The following is a list of some of the conclusions reached in this case study regarding the generation of civic social capital. This will be followed by a summary of the findings in this study as relates to these key points. ${ }^{1}$

1. Civic social capital is generated through zones of conflict, situations of social tension between two or more power systems.

2. It is during these points of conflict that new networks are formed, allowing the transfer of ideas, information, and resources, which in turn leads to the generation of civic social capital.

3. Religion and politics are social networks that intersect, allowing for a flow of symbols, images, and other cultural information back and forth between the two spheres. In this way, civic social capital, thus accumulated in the religious sphere may be converted to the political and vise versa. (Values and virtues, taken from religious 
teachings, important to the cultivation of a moral order of any given society flow through these networks.)

4. Attitudes of trust and norms of reciprocity derive from collective action and in turn become the fuel that powers civic social capital formation.

5. Actions taken to strengthen a group's identity (including developing a group selfunderstanding, sense of place in history, and a set of values and aspirations) enable cooperation among its members, and thus the generation of civic social capital.

6. A group's civic social capital increases when its radius of trust is extended.

7. When social groups create ties to other social groups beyond the confines of their intimate circle, civic social capital is increased. Conversely, when groups cannot establish ties to these groups, civic social capital is decreased.

8. Civic social capital is dependent on the sustained and synergistic interaction between civil society and government.

Two factors contributed to Perrine's accumulation of civic social capital during the first half of the twentieth century: the conflict between Perrine's blacks and the dominant system, and the shared norms, values and trust that developed within the networks Perrine's blacks formed as they engaged in this conflict. In an environment that 
sought to exclude blacks from participation in the dominant political system, blacks in Perrine accumulated civic social capital by way of their struggle with that system, for education, police protection, and services usually supplied by a municipality. They formed networks with other blacks throughout the region, but also, and importantly, with local whites, with whom they shared a common interest, that of forging a viable community in the face of 1) the rigors of frontier life and 2) competition with other areas of Dade County over goods and services the county government would provide. Blacks and whites found common ground, albeit in a two-tiered unequal system, that of creating and maintaining a stable community suitable for raising families and making a living. The Model Land Company, the institution most responsible for Miami's early economic and political development, shared this vision. Company policy reflected the understanding that stable, well ordered communities (in which religious institutions play a role) would increase company profits.

Perrine's black community exhibited high levels of civic social capital throughout the first half of the twentieth century as measured by the extensive scope of its political participation. At a time and place when a bi-racial cooperative government would be unthinkable, Perrine's blacks participated in forming such a governing body. Other indications of the high levels of trust that facilitated cooperation between blacks and whites include the expressed dismay of the state trooper that the police force would not be able to protect the citizens of Perrine against Ku Klux Klan violence and the inclusive nature of the theological frameworks that were foundational for black religious life in Perrine. 
By 1948 a confluence of social processes began to manifest which impacted negatively on black Perrine's accumulated civic social capital and its ability to generate more such capital. During this second phase there were a number of large-scale occurrences that led to shifts in power arrangements, the dismantling of black Perrine's networks, and Perrine's black community being left less involved in the political process than it formerly had been. Large-scale population increases in Miami, an expanding county power base, and increased development which began to encroach on farms in South Dade led eventually to Perrine's white growers selling their farms and moving away. Perrine's white citizens as well as its blacks lost local political control to big government. A period of rapid suburbanization led to increased isolation of Perrine's now all black community, due to policies implemented decades earlier: segregated neighborhoods had been insured through decades of Federal public policies, including red-lining. Large numbers of blacks, forced to live in segregated neighborhoods with blacks from differing backgrounds, moved to Perrine, including those relocating from Miami's slum areas into new public housing projects and others migrating from the north. Communities begin to break down when members do not share common values. Perrine's original black citizens were unable to integrate these new groups, many of whom had very different values and lifestyles. Beginning in the 1970s, new groups of blacks from the Caribbean entered Perrine, adding further to Perrine's difficulty in absorbing outsiders. The fact that different ethnicities were forced to live together in the same community despite their differences was one of the most important factors in Perrine's declining civic social capital in subsequent years. School desegregation in 
1966 was another contributing factor leading to the disruption of Perrine's communal values and to the decline in civic social capital.

Diminished civic social capital was evident by the lack of cohesion among Perrine's churches during this second period, exemplified by a proliferation of churches, each with exclusionary memberships. Differing values among groups led to the deterioration of informal social controls. Perrine was left to the mercy of a range of individuals, from slum landlords to drug lords, each seeking individual profit at the expense of the community. Perrine's original group of citizens developed strong rather than weak ties and the radius of trust between community members narrowed, with a reduction in joint cooperation.

Conflicts, subsequent political restructurings, and new sets of shared norms and values engendered by new alliances led to the generation of civic social capital beginning in the 1980s. In this last phase, energy was directed inwardly against discreet components of Perrine's community and against harmful influences thought to be endangering the foundational institution of their community, the family. Zones of conflict were variously identified by different groups as being "against the drug lords," "against secularism," and "against moral failings and church corruption."

New zones of conflict engendered generation of civic social capital by way of weak ties, networks involving broadly-based social groups. A key event, the Lee Arthur Lawrence murder, provided the stimulus for large-scale civic social capital production and increased political participation with a series of chain reactions. First, Perrine's churches put aside their differences and came together in common cause, reaffirming values, long dormant, those of civic responsibility and a commitment to community and 
youth. Then ties were established between Perrine's churches and outside groups, enabling resources to be brought into the community. The first new network included the neighboring middle-class neighborhood of Richmond Heights. Its spokesman, Rev. Richardson, expanded that network county-wide to include outside churches. Eventually local media attention attracted State Attorney Janet Reno, who established the NRT, a broad-based delivery system that harnessed local community resources and brought governmental and private resources into Perrine. Networks were also expanded within the wider black community to include the more broad-based religious and political institutions (among them, the NAACP, the National Urban League, and National Baptist Convention USA), harnessing resources which in turn strengthened local religious institutions.

Just as social processes and events can have a great impact, both positive and negative, on the generation of civic social capital, so can individuals. This case study has demonstrated the positive effects certain individuals with powerful visions and the means to implement them can make to the generation of civic social capital. The list of these individuals is quite long and although it is impossible to minimize the contribution each one has made to the generation of civic social capital, a few individuals stand apart, because they were leading visionaries whose efforts had particularly far reaching positive implications. These individuals are Henry Flagler, Arthur and Polly Mays, Frank C. Martin, Ron Tookes, and Janet Reno.

Strong group identities promote the generation of civic social capital by consolidating important values and important cultural information needed to facilitate collective action. Segregation itself served in some ways to strengthen an African 
American identity by binding blacks together in their dealings with a two-tiered society. Many examples of identity formation have been demonstrated in this case study. Immigrants and migrants throughout Perrine's history have formed churches according to their place of origin, enabling these groups to transport, preserve and transmit important values important for creating and maintaining their new communities. Bahamians and Jamaicans, in particular, came with a strong work ethic, family values, and desire for economic advancement as well as an independence of spirit. The community as a whole developed stories about itself, such as the "Incorporation Story," and commemorated events, such as the murder of Lee Arthur Lawrence, to pass along important cultural information to succeeding generations, such as the importance of community and civic engagement. At the close of the twentieth century, churches focused on black history in an attempt to cultivate pride in black heritage and reconnect youth to their past.

Religious institutions in general contribute to the generation of civic social capital by socializing autonomous individuals into members of a community with shared interests and a sense of the common good. Perrine's churches have undertaken this formidable task. In many instances they have taken over the role of the family, which is the primary institution in any civil society, and which, in the black community, has been severely ruptured. In particular, they socialize young black males, attempting to shape their character, instilling in them a sense of social conscience, and helping to turn them into productive members of society. They turn young men who exhibit a very narrow radius of trust and expand their radius of trust outwardly towards the larger society. Finally, this case study has shown the many ways religious resources have been used to generate civic social capital. One example involves the use of a religious 
movement to reform and restore a moral order to society. From Perrine's earliest years, the Holiness movement has functioned in this capacity, as the pietist element in American Protestantism has in relation to the larger culture. A second example shows how two religious rituals, prayer and "preaching the word" have been used by groups in Perrine to unify and to define their community, to establish goals, to incite, to empower, and to transform, allowing the civic social capital to flow from the religious sphere into the political and vise versa. Partnering with God increases the level of civic social capital. One last example involves the use of national cultural symbols taken from JudeaChristian symbolism to map a political identity. When Bishop Ingraham spoke of the sacred nature of his journey from the Bahamas to the United States for the purpose of "seeking better religion" he was linking his religious group's purpose to that of the Puritans, who fled what they believed to be an unfair system in England to build a new political system in the "Promised Land." As well, Rev. Richardson in the prayer he delivered at the NRT meeting cited in the Prologue of this study, invoked central national cultural ideals of justice and peace that linked God's Kingdom of Heaven on Earth to America's political system. Both Bishop Ingraham's and Rev. Richardson's use of this religious and political symbolism contribute to the generation of civic social capital increasing the radius of trust the groups they represent outwardly towards the greater humanity. 
NOTES

${ }^{1}$ Most of these conclusions are taken or adapted from concepts, insights, and theories developed by social scientists discussed in this thesis and have already been cited. 


\section{List of References}

\section{Works Cited}

\section{Archive Sources}

Model Land Company Records, Archives and Special Collections, University of Miami, Coral Gables, Florida.

\section{Books}

Anderson, Robert Mapes. Vision of the Disinherited: The Making of American Pentecostalism. New York: Oxford University Press, 1979.

Baer, Hans A., and Merrill Singer. African American Religion: Varieties of Protest and Accommodation. Knoxville: The University of Tennessee Press, 2002.

Baron, Stephen, John Field, and Tom Schuller. Social Capital: Critical Perspectives. New York: Oxford University Press, 2000.

Bellah, Robert. "Civil Religion in America," in Beyond Belief: Essays on Religion in a Post-Traditional World. New York: Harper and Row,1970, 168-193.

Berger, Peter L., and Thomas Luckmann. A Social Construction of Reality: A Treatise in the Sociology of Knowledge. Garden City, New York: Doubleday \& Company, 1966.

Billingsly, Andrew. Climbing Jacob's Ladder: The Enduring Legacy of AfricanAmerican Families. New York: Simon and Schuster, 1992.

. Mighty Like a River: The Black Church and Social Reform. New York, Oxford

University Press, 1999.

DiLulio, John J. Jr. The Lord's Work: The Church and Civil Society. Edited by E. J. Dionne Jr. Community Works: The Revival of Civil Society in America. Washington D.C.: The Brookings Institution, 1998.

Drake, St. Clair and Horace R. Cayton. Black Metropolis: A Study of Negro Life in a Northern City. New York: Harper and Row, 1945.

Dunn, Marvin. Black Miami in the Twentieth Century. Miami: University Press of Florida, 1997. 
Durkheim, Emile. The Elementary Forms of Religious Life, trans. Joseph Ward Swain. New York: Free Press, 1965.

Elazar, Daniel J. Building Cities in America: Urbanization and Suburbanization in a Frontier Society. Lanham, MD: Hamilton Press, 1987.

Frazier, E. Franklin. The Negro Family in the United States. Chicago: University of Chicago Press: 1966.

Francis Fukuyama. The Great Disruption: Human Nature and the Reconstitution of Social Order. New York: The Free Press, 1999.

Chidester, David. Patterns of Power: Religion and Politics in American Culture. Englewood Cliffs, New Jersey: Prentice Hall, 1998.

Gannon, Michael, ed.. The New History of Florida. Gainsville: University Press of Florida, 1996.

Geertz, Clifford. The Interpretation of Cultures. New York: Basic Books, 1973.

Green, David G. "Community without Politics." in Peter L. Berger and Richard John Neuhaus. To Empower People: From State to civil Society. Washington D.C. The AEI Press, 1996.

Himmelfarb, Gertrude. One Nation, Two Cultures. New York: Vintage Books, 1999.

Howard, Rosalyn. Black Seminoles in the Bahamas. Gainsville, Florida: University Press of Florida, 2002.

Johnson, Whittington B. Race Relations in the Bahamas, 1784-1834: The Nonviolent Transformation from a Slave to a Free Society. Fayetteville: The University of Arkansas Press, 2000.

Lincoln, C. Eric. Race, Religion, and the Continuing American Dilemma. New York: Hill and Wang, 1984, 1999,

Lincoln, C. Eric, and Lawrence H. Mamiya. The Black Church in the African American Experience. Durham: Duke University Press, 1990.

Mitchell, Henry H. "Toward a Theology of Black Preaching," in African American Religious Studies: An Interdisciplinary Anthology. Gayraud Wilmore, ed. Durham: Duke University Press, 1989.

Moore, Deborah Dash. To the Golden Cities: Pursuing the American Jewish Dream in Miami and L.A. Harvard University Press: Cambridge, 1994. 
Mohl, Raymond A. South of the South: Jewish Activists and the Civil Rights Movement in Miami, 1945-1960. University Press of Florida: Gainesville, 2004.

Myrdal, Gunnar. An American Dilemma: The Negro Problem and Modern Democracy. New York: Harper \& Row, 1962 (orig. ed., 1944).

Porter, Bruce and Marvin Dunn. The Miami Riot of 1980. Lexington, Mass: Lexington Books, 1984.

Portes, Alejandro and Stepick, Alex. City on the Edge. Berkeley: University of California Press, 1993.

Provenzo, Asterie Baker, and Eugene F. Provenzo. Education on the Forgotten Frontier: A Centennial History of the Founding of the Dade County Public Schools. Miami: Dade County Public Schools, 1985.

Putnam, Robert. Making Democracy Work: Civic Traditions in Modern Italy. Princeton: Princeton University Press, 1993. . Bowling Alone: The Collapse and Revival of American Community. New York; Simon and Schuster (2000)

Raboteau, Albert J. A Fire in the Bones: Reflections on African-American Religious History. Boston: Beacon Press, 1995.

Rainwater, Lee and William L. Yancey. The Moynihan Report and the Politics of Controversy: Including the full text of The Negro Family: The Case for National Action by Daniel Patrick Moynihan. Cambridge, Massachusetts: The M.I.T. Press, 1967.

Rivers, Eugene F. III. "Effectiveness over Ideology: Church-Based Partnerships in Crime Prevention." Edited by E. J. Dionne, Jr. and Ming Hsu Chen. Sacred Places, Civic Purposes: Should Government Help Faith-Based Charity? Edited by. Washington D.C: The Brookings Institution: 2001.

,"High-Octane Faith and Civil Society." in E. J. Dionne Jr., eds. Community Works: The Revival of Civil Society in America. Washington D.C.: The Brookings Institution, 1998, 59-63.

Sanders, Cheryl J. Saints in Exile: The Holiness-Pentecostal Experience in African American Religion and Culture. New York: Oxford University Press, 1996.

Sherman, Amy L. Reinvigorating Faith in Communities. Fishers, IN: Hudson Institute, 2002. 
Smidt, Corwin ed. Religion as Social Capital: Producing the Common Good. Waco, Texas: Baylor University Press, 2003

Smith, Theophus H. Conjuring Culture: Biblical Formations of Black America. New York: Oxford University Press, 1994.

Sobel, Mechal. Trabelin' On: The Slave Journey to an Afro-Baptist Faith. Westport, Connecticut: Greenwood Press, 1979.

Taylor, Jean. Villages of South Dade. St. Petersburg, Fla: Byron Kennedy and Company, 1986.

Tocqueville, Alexis de. Democracy in America. trans. and ed. Harvey C. Mansfield and Delba Winthrop. Chicago: University of Chicago Press, 2000.

. Memoir on Pauperism. trans. Ivan R. Dee, Inc. introduction by Gertrude Himmelfarb. Chicago: Ivan R. Dee, 1997.

Tweed, Thomas A., ed. Retelling U.S. Religious History. Englewood Cliffs, New Jersey: Prentice Hall, 1998.

Weber, Max. The Theory of Social and Economic Organization. New York: Free Press, 1947.

Wilmore, Gayraud. Black Religion and Black Radicalism: An Interpretation of the Religious History of Afro-American People. Maryknoll, New York: Orbis, 1983.

\section{Journal and Magazine Articles}

Arana, Ana. "How the Street Gangs Took Central America." Foreign Affairs May/June (2005): 98-110.

Andrews, Doug. "Black Education in Miami, 1921-1940." Tequesta LIV (1999): 30-51.

Brown Jr., William E. and Hudson, Karen. "Henry Flagler and the Model Land Company." Tequesta LVI, (1996): 47-78.

Berger, Peter. "Secularism in Retreat," National Interest no. 46 (Winter 1996/97): 312.

Dodd, Dorothy D. "The Wrecking Business on the Florida Reef: 1822-1860," Florida Historical Quarterly, XXII, no. 4 (April 1944): 171-199. 
Fukuyama, Francis. "Social Capital and Development: The Coming Agenda," SAIS Review 23 no.1 (Winter/Spring 2002): 23-37.

George, Paul S. and Thomas K. Peterson. "Liberty Square: 1933_1987: The Origins and Evolution of a Public Housing Project," Tequesta 48 (1988): 53-78.

George, Paul S. “Policing Miami’s Black Community 1896_1930.” Florida Historical Quarterly LVII \#4 (April 1979):434-450.

. “Colored Town: Miami's Black Community, 1896-1930." Florida Historical Quarterly 56 (April 1978): 432-447.

Goggin, John M. "The Seminole Negroes of Andros Island, Bahamas." Florida Historical Quarterly, XXIV, no. 3 (Jan. 1946): 200-206.

Granovetter, Mark S. "The Strength of Weak Ties." American Journal of Sociology 78 (1973): 1360-1380.

Mohl, Raymond A. "Black Immigrants: Bahamians in Early Twentieth Century Miami." Florida Historical Quarterly LXV \#3 (June 1987): 271-297.

."Miami's Metropolitan Government: Retrospective and Prospect." Florida Historical Quarterly LXIII, no. 1 (July 1989): 24-50.

. "Making the Second Ghetto in Metropolitan Miami, 1940-1960." Journal of Urban History, (March 1995): 395-427.

"Shadows in the Sunshine: Race and Ethnicity in Miami," Tequesta, XLIX (1989): 63-80.

. "Whitening Miami: Race, Housing, and Government Policy in Twentieth_Century Dade County," Fla. Historical Quarterly Vol 79 no. 3 (2001): 319-345.

. "Elizabeth Virrick and the "Concrete Monsters": Housing Reform in Postwar Miami," Tequesta (2001): 5-33.

Mormino, Gary R. "Midas Returns: Miami Goes to War, 1941_1945." Tequesta LVII (1997): 5-51.

Peters, Thelma. "The Loyalist Migration from East Florida to the Bahama Islands." Florida Historical Quarterly XXXX (1961): 123-141. . "Miami's First School." Update Vol. 1 no. 3 (Feb. 1974): 6-7. 
Porter, Kenneth W. "Notes on Seminole Negroes in the Bahamas," Florida Historical Quarterly XXIV (July 1945), 56-60.

Portes, Alejandro."Social Capital: Its Origins and Applications in Modern Sociology," Annual Review of Sociology. 24 (1998):1-24.

Portes, Alejandro. "Social Capital: Promise and Pitfalls of its Role in Development," Journal of Latin American Studies 32 (2000): 529-547.

Sherman, Amy L. "Get with the Program; Mainline Churches Drag their Feet on Welfare Reform", The American Enterprise v. 8 (January/February 1997): 65-8.

Shofner, Jerrell H. "Florida and the Black Migration." Florida Historical Quarterly XVII no. 3 (Jan. 1979): 267-288.

Taylor, Jean. "Scarifying South Dade.” Update Vol. V no. 1 (October 1977): 4-5

Vought, Kip. "Racial Stirrings in Colored Town: The UNIA in Miami during the 1920's," Tequesta: The Journal of the Historical Association of Southern Florida 60 (2000): 56-76.

Woolcock, Michael. "Social Capital and Economic Development: Toward a Theoretical Synthesis and Policy Framework." Theory and Society 27/1 (1998): 151-208.

. "Why and How Planners Should Take Social Capital Seriously." Journal of the American Planning Association 70 no. 2 (Spring 2004): 183-189.

\section{Internet Publications}

Anderson, George M. "Addressing Youth Crime: An Interview with Eugene F. Rivers." (30 September, 2000) 4 September, 2005.

http://www.americamagazine,org/gettext.cfn?articleTypeID=1\&textID=2204\&iss ueID $=382$

Berrien, Jenny and Christopher Winship. "Should We Have Faith in the Churches? The Ten-Point Coalition's Effect on Boston's youth Violence." (July 1999) 2 September, 2005 http://www.wjh.harvard.edu/soc/faculty/Winship/Winshipp1.

Himmelfarb, Gertrude. "Democratic Remedies for Democratic Disorders." 14 December, 2004 http://www.thepublicinterest.com/notable/articles8.html.

Rivers, Rev. Eugene F. III. "Challenge from Within: A Call to Address the Black Church Leadership." (2001) 4 September, 2005. http://www.tgsrm.org/Church\%20Leadership\%20Crisis.html. 
Streeter, Ryan "Charitable Choice as Historical Phenomenon and Future Reality." Welfare Policy Center, Hudson Institute (Jan 1, 2001) http://www. WelfareReformer.org.

"Direction of Black Churches Unclear." Baltimore, 29 March, 2005. http://www.churchfolk.com/msgboard/messages/2305.shtml.

\section{Unpublished Interviews}

Alexander, Delores Pastor, pastor of Faith Triumph Church of God in Christ in Goulds. Interview by author, 11 April 2002, Perrine, Florida. Tape recording.

Bannerman, Wayman, assistant to Commissioner Dennis Moss. Interview by author, 29 November 2001, Steven Clark Government Center,Miami, Florida. Tape recording.

Bell, Rev., pastor of Mt. Sinai Baptist Church in Perrine. 23 October 2001, Perrine, Florida.

Brown, Sister, secretary of St. Peters Missionary Baptist Church, Perrine. 5 February 2002, Perrine, Florida.

Bruton, John, member of Mt. Moriah Missionary Baptist Church, Perrine. Interview by author, 28 November 2001, Perrine, Florida. Tape recording.

Carroll, Rev. Ben, assistant pastor at New Birth Baptist Church, North Miami. Interview by author, 7 November 2001, North Miami, Florida. Tape recording.

Ferguson, Emma (pseud.), resident of Perrine. Interview by author, 5 December, 2002.

Freeman, Rev. Norman, youth pastor of Sweet Home Missionary Baptist Church, Perrine. Interview by author, 24 October 2000, Perrine, Florida. Partial tape recording. . Interview by author, 3 April 2001, Perrine, Florida. Tape recording.

Finkley, Archie, member of Mt. Sinai Baptist Church, Perrine. Interview by author, 15 February 2002, Perrine, Florida. Tape recording. . Interview by author, 20 February 2002, Perrine, Florida. Tape recording.

Gordon, Rev. C., pastor of Emmanual Apostolic, Perrine. Interview by author and Christian Ho, 20 September 2001, Perrine, Florida. Tape recording. 
Green, Shirley, [pseud.] pastoral counselor at Faith in Christ Holiness Church [pseud.], Perrine. Interview by author, 28 March 2001, Perrine, Florida. Tape recording. . Interview by author, 19 October 2001, Perrine, Florida. Tape recording. . Interview by author, 1 April 2002, Perrine, Florida. Tape recording.

Ingraham, Bishop Joseph, Bishop of Community Church of Christ Written in Heaven, Perrine, and Mrs. Ingraham, his wife. Interview by author, 30 January 2003, Perrine, Florida. Tape recording. . Interview by author, 1 April 2002, Perrine, Florida. Tape recording.

Jefferson, Vester, member of Mt. Sinai Baptist Church, Perrine, Delores Finkley, and Archie Finkley. Interview by author, 25 March 2002, Perrine, Florida. Tape recording.

Marshall, Rev., pastor of Mt. Moriah Missionary Baptist Church, Perrine. Interview by author, 16 November 2001, Perrine, Florida. Tape recording.

McCloud, Vanessa (pseud.), member of Bethel Full Gospel Ministry, Richmond Heights. Interview by author, 5 December, 2002, Kendall, Florida.

Peters, Rev. Rick, youth pastor of Bible Baptist Missionary Church, Liberty City. Interview by author, 18 February 2001, Liberty City, Florida. Tape recording.

Reno, Janet, Dade County State Attorney and U.S. Attorney General. Interview by author, 19 May 2005, Kendall, Florida. Tape recording.

Richardson, Rev. Dr. Walter, pastor of Sweet Home Missionary Baptist Church, Perrine. Interview by Alex Stepick and author, 2 November 2000, Perrine, Florida. Tape recording. . Interview by author, 15 January 2002, Perrine, Florida. Tape recording.

Shackelford, James, son of Neil Shackelford of Hurst Chapel AME, Perrine. Interview by author, 18 March 2002, Perrine, Florida. Tape recording.

Smith, Rev., pastor of Hurst Chapel AME, Perrine. Phone interview by author, 14 November 2001, Perrine, Florida.

Sumpter, Rev. Joseph., pastor of St. Peters Missionary Baptist Church, Perrine. Interview by author, 1 March 2001, Perrine, Florida. . Interview by author, 12 February 2002, Perrine, Florida. Tape recording. 
Tookes, Police Officer Ron, head of the South Florida NRT's. Interview by author, 7

December 2001, Perrine, Florida. Tape recording.

Walden, Bishop, Bishop of Perrine New Testament Church of God, Perrine. Interview by author and Christian Ho, 12 October 2001, Perrine, Florida. Tape recording.

Watson, Bishop Simeon., Bishop of Pentecostal Church of Our Lord and Savior Jesus Christ, Perrine. Interview by author, 30 March 2001, Perrine, Florida. Tape recording. . Interview by author, 29 June 2001, Perrine, Florida. Tape recording.

Wilkinson, Rev. Joseph [pseud.] pastor of Perrine Church of God [pseud.], Perrine. Interview by author, 14 March 2002, Perrine, Florida.

Williams, Fannie Mae and Sinclair, members of St. Peters Missionary Baptist Church, Perrine. Interview by author, 13 March 2002, Perrine, Florida. Tape recording.

\section{Unpublished Participant Observations}

Bible Baptist Church service. 18 February 2001, Liberty City, Florida.

Bible Baptist Religious School. 22 February 2001, Liberty City, Florida.

Bible Class at Coral Reef High School. 24 October 2000, Richmond Heights, Florida.

Community Church of Christ Written in Heaven Church service. 16 September 2001, Perrine, Florida. Partial tape recording.

. Youth Group Observation. 06 November 2001, Perrine Florida.

. Bible Class. 13 November, Perrine, Florida.

Community Meeting at Pentecostal Church of Our Lord and Savior Jesus Christ. 19 March 2001, Perrine, Florida. Partial tape recording.

Emmanuel Apostolic Church Bible Study Class and Church service. 11 February 2001, Perrine, Florida.

Interfaith Prayer Meeting at Temple Judea. 23 September 2001, Coral Gables, Florida. Tape recording. 
West Perrine Mapping, 1 March 2001, Perrine, Florida.

Mapping West Perrine. 10 September 2001, Perrine, Florida.

New Birth Baptist Church service. 12 January 2001, North Miami, Florida.

NRT meeting. 28 November 2001, Perrine, Florida. Partial tape recording.

Perrine New Testament Church of God Church service. 25 March 2001, Perrine, Florida.

Revival at St. Peters Missionary Baptist Church. 20 February 2002.

South Florida Youth Ministries Meeting. 5 December 2000, Coral Park, Florida.

Sweet Home Missionary Baptist Church 7:45 Church Service. 24 September 2000, Perrine, Florida. Partial tape recording.

Sweet Home Missionary Baptist Church Bible Study Class. 24 September 2000, Perrine, Florida.

Sweet Home Missionary Baptist Church 7:45 Church Service. With Sarah Mahler. 11 February 2001, Perrine, Florida. Partial tape recording.

Sweet Home Missionary Baptist Church Youth Group Meeting. 2 October 2000, Perrine, Florida.

West Perrine Christian Association Meeting. 27 March 2001, Perrine Florida. Partial tape recording.

\section{Other Publications}

Other Publications, in author's possession.

Pamphlet: "Neighborhood Resource Team South Dade Community Partnership, 2001_2002"

White, Dr. Cathy. "Pioneers of Perrine."

"Miami Chapter/American Institute of Architects West Perrine Charrette: AIA Florida/Design Assistance Team," November 13 and 141992. 


\section{Selected List of Sources Consulted}

\section{Books}

James H. Cone and Wilmore, Gayraud S. Black Theology: A Documentary History, Vol I 1966_1979. Maryknoll, N.Y: 1993.

Clarke, Peter B., ed. New Trends and Developments in African Religions. Greenwood Press, Westport, Ct: 1998.

Clayton, Horace R. and Drake, St. Claire. Black Metropolis. New York: Harper and Row, 1962.

Hirsch, Arnold R and Raymond A. Mohl. Urban Policy. New Brunswick: Rutgers University Press, 1993

Lincoln, C. Eric, ed. The Black Experience in Religion. Garden City: Anchor Books, 1974.

Long, Rev. Charles Sumner. History of the A.M.E. Church in Florida. Philadelphia: A.M.E. Book Concern, 1939.

Mays, Benjamin Elijah and Joseph William Nicholson, The Negro's Church, New York: Arno Press and The New York Times, 1969. (Copyright 1933)

Mohl, Raymond A. "Miami: New Immigrant City," in Searching for the Sunbelt: Historical Perspectives on a Region. Knoxville: The University of Tennessee Press, 1990.

"Race and Space in the Modern City: Interstate_95 and the Black Community in Miami." in Urban Policy in Twentieth Century America, edited by Arnold R. Hirsch and Raymond A. Mohl. New Brunswick, N.J.: Rutgers University Press, 1993.

. "Trouble in Paradise: Race and Housing in Miami during the New Deal Era." in The Making of Urban America, edited by Raymond A. Mohl. Wilmington, Delaware: Scholarly Resources Inc, 1988.

.. "The Pattern of Race Relations in Miami since the 1920's." in The African American Heritage of Florida, edited by David R. Colburn and Jane L. Landers. Miami: University Press of Florida, 1995.

Moton, Robert Russa, What the Negro Thinks. Garden City, N.Y.:Doubleday, Doran and Company, Inc., 1929. 
, Finding a Way Out, Garden City, N.Y.:Doubleday, 1920.

Peterson, Brian, ed. Blacks in Miami, 1896-1990. Miami: Florida International University, History Department, 1990.

Reid, Ira DeA. The Negro Immigrant: His Background, Characteristics and Social Adjustment, 1899-1937. New York: AMS Press, 1970. 


\section{Appendix}

At the time of this writing I counted 22 religious institutions within West Perrine's boundaries, all Protestant except for one Hindu Temple and a Mosque. Residents said that Perrine had 48 churches before Hurricane Andrew. The four mainline historic churches, established by the mid 1920s, still exist. These are Hurst Chapel AME, Mt. Moriah Missionary Baptist Church, Mt. Sinai Baptist Church, and Kerr Memorial (United Methodist). Rev. Robert Bruce Ingraham's Holiness Church closed at the time of his passing in 1965 but was opened a short time later when his son, Joseph Ingraham, had a conversion experience and was called to the ministry. Two additional mainline churches were established in Perrine in mid-century, Sweet Home Missionary Baptist Church and St. Peter's Missionary Baptist Church. St. Peters was originally begun as a Bahamian Church, but today is mostly American. The other churches were established in the Holiness/Pentecostal tradition, as Holiness, Pentecostal or Apostolic Churches.

The following is a list of Perrine's churches, with the number of members if known. ${ }^{1}$

Kingdom of God

Bibleway Church of Our Lord of the Apostolic Faith (Elder Donald L. Henry)

Pentecostal Church of Our Lord and Savior Jesus Christ (Bishop Simeon Watson);membership: 40 
Community Church of Christ Written in Heaven (Bishop Joseph Ingraham); membership: between 40-100.

The Church of God of Prophecy (Pastor Rosa McIntosh)

Holy Faith Tabernacle Deliverance Center Apostolic Faith (Bishop Ronald Berry)

Sweet Home Missionary Baptist Church (Rev. Walter Richardson) membership: 2000.

The House of God (Robert E. Lee, diseased)

(No name: this one room church, with mowed lawn, looks like it has been boarded up since the Hurricane).

Mt. Calvary National Church of God (Pastor B. L. Rolle)

New Hope Church of God of Deliverance

Christian Converts for Christ Ministries (Prophet: Marion Parnel)

(Church being built: Pastor Alpheus Ferguson)

Mt. Sinai Baptist Church (Pastor R. M. Bell) Membership: 500

Hurst Chapel AME (Pastor Mendalla Smith) Membership: 100

Kerr Memorial (United Methodist): membership: 340 (140 active)

Triumph Church and Kingdom of God in Christ

Evangelist Mission Church of God in Christ (Elder A.C. Day)

New Testament Church of God (Pastor James Walden), membership: 60 (youth)

Mt. Moriah Missionary Baptist Church (Rev. K. L. Marshall) membership: 250

( 75 youth) 
St. Peter's Missionary Baptist Church (Rev. Joseph L. Sumpter, membership 800 (450 active)

Emanuel Apostolic (Elder C. Gordon), membership: 200 


\section{NOTES}

${ }^{1}$ These numbers are inexact. Pastors tend to keep these lists and they can reflect a range of membership types, from members who attend every Sunday to those who only occasionally attend. Some keep records according to families, others according to individuals. 